\title{
Paradoxical Desire in the Poetry of Sidney, Spenser, Donne, and Herbert
}

\author{
By \\ Qiwei (Francis) He
}

A thesis submitted to the Victoria University of Wellington in fulfilment of the requirements for the degree of

Master of Arts

in English Literature

Victoria University of Wellington

2020 



\section{Contents}

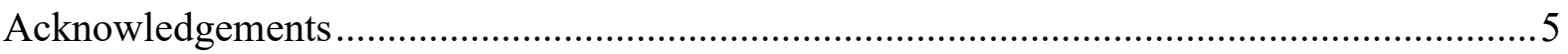

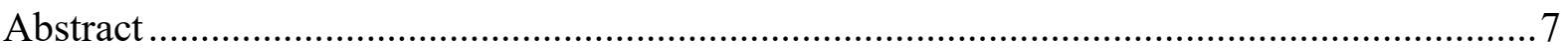

Introduction: The Problem of Desire, the Problem of Paradox .............................................. 1

1. From Sidney to Donne, and the Petrarchan Lover's Paradox .......................................20

1.1 Sidney’s Paradoxical Lover in Astrophil and Stella ...................................................22

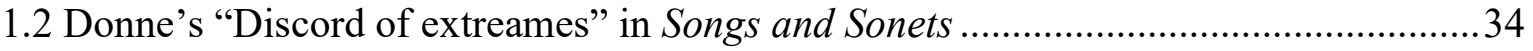

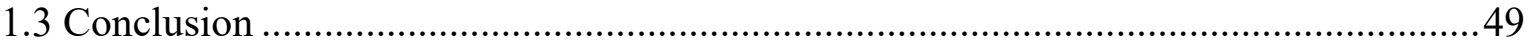

2. Spenser's Paradoxical Body and the Sidneys' Neoplatonic Psalmist .............................51

2.1 Spenser's “chast desires" in Amoretti and Epithalamion ...........................................53

2.2 The Sidneys' Neoplatonic Psalmist, a "right poet" ...................................................65

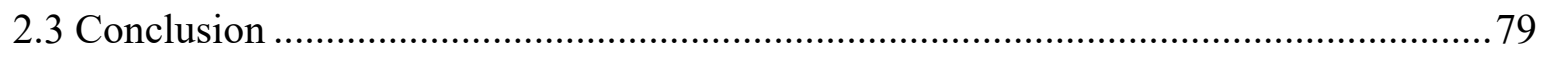

3. Donne's Mediation of Desire and Herbert's Sacramental Eroticism ..............................81

3.1 "contraryes meete in one": Donne's Mediation of Desire .............................................8 82

3.2 Herbert's Sacramental Eroticism: the Paradoxical Formula.......................................96

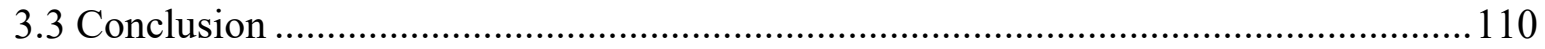

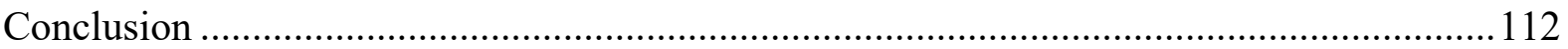

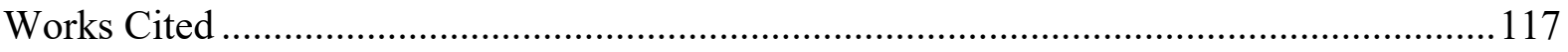





\section{Acknowledgements}

I owe my greatest thanks to my supervisor Sarah Ross, for her most patient guidance and resourceful input throughout the writing of this thesis. Thanks also to my dear parents without whose support I would not have had such a precious opportunity to study at Victoria University of Wellington. I am also grateful to Madeleine Collinge for her assistance in proofreading my thesis. 



\begin{abstract}
Inspired by conventional Petrarchism, early modern English poets adopted the concept and rhetoric of paradox in their articulations of desire while revealing significant progression and innovation. Desires expressed by the poet-lovers in the poems of Philip Sidney, Edmund Spenser, John Donne, and George Herbert are the culmination of attempts to coordinate incongruent and contrasting extremes. This thesis examines how desire operates as paradox in Philip Sidney's Astrophil and Stella, Philip and Mary Sidney's Psalms, Spenser's Amoretti and Epithalamion, Donne's amorous and religious poems, and Herbert's poems.
\end{abstract}

Chapter One discusses Astrophil's desire in Astrophil and Stella as demonstrating the Petrarchan lover enfolded in Neoplatonism. It also explores Donne's amorous poems, which apply religious vocabularies to communicate sexual love, filling the gap between the distant extremes, establishing a paradoxical unity. In Chapter Two, the thesis compares Spenser's speakers in Amoretti and Epithalamion and the Sidneys' Psalmist as Neoplatonic lovers, both of whom search within the physical realms - nature and the body - to express the desire for their divine beloved. In Chapter Three, I compare Donne's religious poems and selected lyrics from George Herbert's The Temple. I argue that in Donne's religious poems, spiritual love is mediated through fleshly desire in a sacramental poetics. The relationship between physical desire and spiritual love is comprehended through sacramental analogy. Comparably, in Herbert's The Temple, the internal and external components of religious desire reflect the Sacramental theories in which Eucharistic elements communicate their divine referents. The effective way to express love for God, paradoxically, is to establish a spiritual justification for an affirmative embrace of sexuality, making fleshly desire serve as a vehicle of Divine grace.

As Donne asserts in his Paradoxes and Problems, "by Discord things increase". The poet-lovers in the works this thesis explores constantly yearn to imitate and represent their beloved by means of "Discord" and the performance of paradoxical unity. Accordingly, paradoxical desire becomes the inevitable consequence of the poet-lover as a desiring subject who approaches a supposedly insuperable obstacle when he correlates with the beloved object. 



\section{Introduction: The Problem of Desire, the Problem of Paradox}

In his youth, John Donne wrote a series of prose pieces wittily discussing the moral and religious concerns of his day, published posthumously in 1633 and known as Paradoxes and Problems. In "Paradox IX", he argues that "by Discord things increase" (19-21). ${ }^{1}$ Donne's statement reflects the ideas in and nature of both his amorous and religious poems, which are famous for their paradoxes. Always, the sense of paradox in his poems is fundamentally occasioned by some kind of "Discord". Such "Discord" bears the meaning of disagreement, discordance, and disharmony - the illogical state of simultaneously being and not beingwhich is the very nature and definition of paradox. For example, in his poem "The Anniversarie", he writes about the simultaneously changing yet preserving nature of love: "Running it never runs from us away, / But truly keepes his first, last, everlasting day" (9-10). ${ }^{2}$ Similarly, in "Loves growth", love is infinite yet at once capable of being added to: "My love was infinite, if spring make'it more" (6).

Paradox is peculiarly appealing to early modern English poets. According to The Routledge Dictionary of Literature Terms, a paradox is an "apparently self-contradictory statement" (166). Similarly, in The Princeton Encyclopedia of Poetry and Poetics, paradox is defined as "a daring statement that unites seemingly contradictory words but that on closer examination proves to have unexpected meaning and truth" (996). This comparatively modern yet not altogether ahistorical definition and usage of "paradox" as a literary-critical term

\footnotetext{
${ }^{1}$ All citations from Donne's Paradoxes and Problems are from John Donne: Paradoxes and Problems, ed. Helen Peters. Oxford University Press, 1980.

2 All citations from Donne's Songs and Sonets are from John Donne: The Complete English Poems, ed. C. A. Patrides. Everyman's Library, 1985.
} 
emerges out of a deep, complex philosophical tradition notable in the Renaissance. Historically, paradox can be traced to the generic tradition of Erasmian humanism, named after Desiderius Erasmus, who wrote The Praise of Folly. Erasmus wrote The Praise of Folly initially to impel readers to unveil the "unexpected meaning and truth", and in this context, paradox refers to speakers "rhetorically dissimulating in arguments against received opinions" ("The paradox" 150). This is the same rationale according to which Donne makes paradoxes, which, as stated by A. E. Malloch, are "not to deceive, but by a show of deceit to force the reader to uncover the truth" (192). When reacting to paradox, the reader will, as John Hoskyns describes in Directions for Speech and Style (c. 1599), "thinke it a strange harmonie which must bee exprest in such discords" (qtd. in Biester 2). Malloch also describes paradoxes as "exist[ing] only within the antithetical action of the reader" (192). Significantly, an antithetical reading action is only realisable when the reader construes the equivocation of the paradoxist who-as Rosalie Colie describes - balances the contradictions against one another "in the equivocal balance in which paradoxy excels" (Paradoxia Epidemica 38). The "argumentation" feature of Donne's poetry has never been neglected by critics, yet my thesis attempts to explore (among other things) paradoxes as statements of these arguments. Malloch points out that paradoxes exist "as statements of arguments (however perverse). [...] They are not, and yet they are" (193). Such is the fundamental nature of paradoxes. They are expressions or articulations of something that is contradictory within itself. This problem was not unique for Donne, but true for many other amorous poets and religious poets in the early modern period.

This thesis will argue that there can be seen a strong continuity in certain ideas and perspectives between certain Elizabethan and Metaphysical poets who are not easily distinguished from each other in relation to their philosophical and theological stance by which they articulate desires. This thesis takes Philip Sidney's Astrophil and Stella and his translation of the Psalms with his sister Mary, Countess of Pembroke, and Edmund Spenser's Amoretti 
and Epithalamion as representatives of Elizabethan poetry, and John Donne's Songs and Sonets and the Holy Sonnets, and George Herbert's The Temple as examples of Metaphysical poetry. By exploring the articulations of paradoxical desire in these respective works, I will seek to suggest that the perception and expression of desire as a paradox developed and evolved over approximately one hundred years of literary history.

The representation of one's love is self-contradictory, or in other words, paradoxical, as exemplified in Donne's particular poems mentioned earlier. Love, as an intense disposition of deep affection, is in itself unstable but firm and it is at the same instant perfect yet lacking. The paradoxical nature of love, the expression of it, and the poetical representation of it is the unavoidable outcome of the disposition of human desires. The love or the beloved of the poetlover is both near and far. Hence, the subject who desires the love or that beloved is involved in a positive progression of moving toward the object and at the same time in a negative position of wanting or lacking that love. Consequently, in the Renaissance love lyric, the poetlover as a desiring subject becomes paradoxical as he "experiences both the negative state of not having something and the positive state of yearning for that thing" (Catherine Bates 108). The poet-lover as a paradoxical subject is clearly voiced by Astrophil of Sidney's sonnet sequence Astrophil and Stella (published in 1591). Astrophil longs for his beloved woman Stella as he composes in the Petrarchan tradition.

The classic Petrarchan paradox is exemplified by a famous verse in the Italian poet Petrarch's Canzoniere, which reads: "I find no peace, and all my war is done; / I fear and hope, I burn and freeze like ice". ${ }^{3}$ This fundamental Petrarchan paradox is articulated by the comparison of various contradictory extremes - similar to Donne's "Discord[s]" - that are represented by the poet-lover who "burn[s] and freeze[s] like ice". In Echoes of Desire, Heather

\footnotetext{
${ }^{3}$ Lines 1-4, Rima 134 in Canzoniere. This English translation is from Thomas Wyatt.
} 
Dubrow states that Petrarchism is "itself a discourse of extremes" which represents a series of paradoxes (15). The kind of desire the poet-lover experiences and performs simultaneously and so paradoxically gives him pleasure and pain. The Princeton Encyclopedia of Poetry and Poetics describes the characteristic features of Petrarchism as including not only the assertion of "unrequited love" but also "psychological alternations between fleshly desire and forced abstinence" (1030). G. F. Waller, when discussing Spenser's Petrarchism, argues that the desiring situation and emotional style of Petrarchism is rooted in a psychology that reflects a pattern of behaviour that can be deemed perverse. ${ }^{4}$ This is also distinctly true for Sidney's Astrophil. According to Waller, the poet-lovers' performance of desiring the idealised woman incorporates Petrarchism with seemingly contradictory sexual fantasies, absorbing alternatively erotic attractions, sadism, and masochistic repulsions. The woman is alluring yet cruel; her chastity is praised yet is almost aggravating at the same time. She is to be idolised by the male poet-lover who desires to own her exclusively; however, once rejected, he castigates her as hard-hearted and punishing. ${ }^{5}$

As Catherine Bates points out, the Petrarchan sonnet tradition is itself "a discourse of desire" (120). Throughout the sequence, Astrophil articulates his desire as paradoxical due to the logically impossible co-existence of his heart and mind, and a struggle between them over whether his beloved deserves his desires. Take Sonnet 4 as an example: Astrophil recognises that "Vertue" has set a "[de]bate betweene [his] will and wit" (2). ${ }^{6}$ In Echoes of Desire, Dubrow discusses the paradox of "moves without moving", which is a consequence of the volatility of the authorial emotions ("Petrarchan Problematics" 19). Dubrow describes the simultaneously existent volere (to wish) and potere (to be able) in their rhetorical sense, and the paradox being

\footnotetext{
${ }^{4}$ See G. F. Waller. Edmund Spenser: A Literary Life. Macmillan Press Ltd. 1994. p. 169.

${ }^{5}$ Though my thesis focuses on male poet-speakers, there is an extensive body of work on female desire, which is framed by English women poets in the early modern period, among whom there is importantly Lady Mary Wroth. ${ }^{6}$ All citations from Astrophil and Stella are from William A. Ringler, Jr., ed., The Poems of Sir Philip Sidney, Oxford University Press, 1962.
} 
a "failure", and that English Petrarchism and its counterdiscourses "recur repeatedly to these paradoxes" (21). In some way, Astrophil, with his paradoxical desire, is a failure. Such a failure is at a primary level the frustration of reconciling "Discord[s]", the logically contradictory and antithetical inclinations of the poet-lover who desires. It is the inevitable consequence of the Petrarchan paradox as based in the Petrarchan experience, which has its origin in the passionate but spiritual nature of human beings.

Paradoxical desire is a philosophical expression of paradoxical emotions deeply rooted in human beings. Later in the Romantic period, Friedrich Schlegel would call the paradox "a basic form of human experience" and connect it "closely with poetry" (Princeton Encyclopedia 996). Paradoxical emotions necessarily produce conflict: conflicting expectations and conflicting values. Conversely, those conflicts then find their metaphysical utterance in paradoxes. This is clearly displayed in Petrarch's sonnet, then revised and developed in Sidney's and Spenser's poetry. For example, in Astrophil and Stella, the paradoxical desire of the poet-lover Astrophil is reflected in his being enthralled by the "Vertue" of Stella at the same instant of being impelled to pursue fleshly fulfilment with her. A similar paradoxical desire for sexual consummation and spiritual fulfilment is also demonstrated by the poet-speaker in Spenser's Amoretti and Epithalamion (published in 1595) in which the conflict of sexual desire with Platonic "vertue" is clearly seen. These conflicts are not merely tensions, but are "Discord[s]" in which the conflicting elements find truthful claims in mutual contradictions.

Within all these conflicts, the philosophical presupposition of Neoplatonism needs to be considered, as it was central to Renaissance philosophical and poetic thought. Both Sidney's Astrophil and Stella and Spenser's Amoretti and Epithalamion display the respective poetlovers as not only Petrarchan but also Neoplatonic. They constantly search for resolution of the problem in which the despair of failing to indulge fleshly desires and the satisfaction of perceiving Platonic ideals as mirrored in the beloved affect them in a mutually discordant 
manner. When the principle of Neoplatonism is mixed into Petrarchism, this is one of the consequences. The Petrarchan paradox then ineluctably develops into a paradox of desire by which the desiring subject enfolds his subsistence into the Neoplatonic discourse. ${ }^{7}$ Neoplatonism maintains that all beauty in the physical and sensible world is an emanatio (emanation) or "radiation" from the One and Absolute - the source of all Goodness, or the Divine archetype (Abrams 223). Hence, the human body is to be desired and praised, not only as the physical representation of beauty but also as the manifestation of spiritual beauty. This inevitably leads to the paradox, according to Michael Raiger, that "the exercise of virtue by the soul in conjunction with the body is required for attainment of the Good, but knowledge of the Good, which is obscured by the bodily senses, is required for the exercise of virtue" (38).

In early modern English poetry, the paradox of Petrarch and of the Neoplatonists also evolves into a more perplexing complication when infused with the religious dispute of the day. On one hand, Puritan sentiment as predominant in the Elizabethan Church opposes the indulgences of the flesh, seeing the human body as sinful and corrupt, demanding strict moral discipline. On the other hand, Reformed Protestant theology is in many ways inherently Neoplatonic and fuelled with humanist views, judgements, and potentials. Donne also sometimes voiced the typical Puritan attitude toward the body. Even though many of his poems such as "The Flea" are much more sexually and corporeally forthright than Puritan poems tend to be, corruption of the flesh echoes the theme of some of his sermons- "All flesh is sinfull flesh; sinfull so, as that it is the mother of sin, it occasions sin" (VII 106). ${ }^{8}$

Not only in Donne's poetry, but also more generally, the desire for bodily beauty and for fleshly consummation with the beloved is endlessly in conflict with the almost religious

\footnotetext{
${ }^{7}$ Throughout the thesis, I use the word "subsistence" as a theological term, meaning the existence proper to a substance or reality.

${ }^{8}$ The Sermons of John Donne, ed. George R. Potter and Evelyn M. Simpson. University of California Press, 19531962. References to Donne's sermons include volume and page references in parentheses.
} 
desire for the sublime and the divine. Yet in the Renaissance, those two desires are equally strong and explicitly logical in their respective articulations. The two desires interlace in the poetry and perform as a paradoxical argument in which — as Malloch states — "there are no first principles [...] Instead, there are a number of equivocations which are connected in a circuit" (195). Thus the paradox "seems on its face to be logically contradictory [...] yet turns out to be interpretable in a way that makes good sense" (Abrams 201). The logically contradictory appearance of these desires is evident in the poetry as the poet-lover expresses at once a strong longing for the spiritually pure and a passionate appreciation of physical charms. Paradoxically, it is interpretable as the two continually conflicting inclinations operating at the same time without diminishing one another. Accordingly, as the two forces strive for control, the poet in his subsistence searches for resolution and reconciliation between those "Discord[s]". The Psalmist David, as identified in the translations of the Psalms started by Philip Sidney and completed after his death by his sister Mary, is a favourable example of this attempted search for resolution. Philip Sidney establishes a claim in A Defence of Poetry that "our erected wit maketh us know what perfection is, and yet our infected will keepeth us from reaching unto it" (25). ${ }^{9} \mathrm{He}$ writes, after proclaiming that the end of all Poesy is "to teach and delight", divinely inspired poets "did imitate the unconceivable excellencies of God. Such were David in his Psalms" (Defence 25). By framing the Psalmist as a Neoplatonic lover who desires the grace and beauty of God via physical terms and earthly mediums, Sidney seems to resolve the conflict between the desire for the bodily and for the spiritual. Later, in Donne's Holy Sonnets and George Herbert's The Temple, the poet-speakers, being aware of their carnal and sinful reality, express in a similar way their spiritual desire for God through a poetics in which sublime thoughts are pronounced through physical language.

\footnotetext{
${ }^{9}$ All citations from Sidney's A Defence of Poetry are from A Defence of Poetry, ed. J. A. Van Dorsten. Oxford University Press, 1966.
} 
However, problems generated from the paradoxical nature of desires are never perfectly solved; hence, the poets establish the appeal of paradox as a poetic device. Apart from the body-soul or fleshly-spiritual paradox, the poet-lovers this thesis discusses articulate their desire as a paradox on another philosophical level in which they deal with the problem of selfidentity and poetical representation. On this level, the desire the poet-lovers express is not merely an ostensibly contradictory statement, but a philosophical and linguistic performance in which the desired object constantly confuses the desiring subject's self-identity. The cause of this problem is not only the inherently conflicting nature of human beings but also, more profoundly, the deficiency of postlapsarian human language itself to articulate desire coherently.

Although this problem of poetic articulation has much to do with both Neoplatonic philosophy and Christian theology, it also finds its essential demonstration in the Petrarchan paradox, as mentioned earlier. The Petrarchan desire that the poet-lover experiences and performs simultaneously gives him pleasure and pain. In Sonnet XLIX from Amoretti, Spenser's speaker becomes involved in a paradox of the "cruel fair", asking, "Fayre cruell, why are ye so fierce and cruell?” (1). ${ }^{10}$ The paradoxical correlation between the desiring subject and the desired object in the secular amorous context is also projected into the religious ambience, particularly reflected in the devotional poetry. The long tradition of using the imagery of marriage to portray the relationship and the union between the believers and God, the medieval symbolism of characterising Christ's relationship to the Church as one of Bridegroom to Bride is given a new voice in some of Donne's Holy Sonnets. Taking "Batter my heart" as an example, the poet-lover, speaking in a feminine persona, desires the masculine God to take him/her over

\footnotetext{
${ }^{10}$ All citations from Amoretti and Epithalamion are from The Yale Edition of the Shorter Poems of Edmund Spenser, ed. William A. Oram et al. Yale University Press, 1989.
} 
completely, to "imprison" him/her in Divine love. He/she asserts that through God's ravishment — the act of Divine rape — he/she will be rendered pure and "chast":

Take mee to you, imprison mee, for I

Except you'enthrall mee, never shall be free,

Nor ever chast, except you ravish mee. $(12-14)^{11}$

Barbara Lewalski remarks on the "paradoxical reversal of Christ's customary relationships with the soul—as liberator [...] and as Bridegroom" (272). This paradox is identified by John Stachniewski as not merely ingenuity; in his words, the paradox "contains complexity of feeling: the ideas of imprisonment, enslavement, and rape [which] are genuinely affronting" (689-690). I further argue that this paradox is initiated in the discordant nature of the desire of the postlapsarian human itself. The shockingly paradoxical expression in the poem reflects not only a paradoxical attitude towards God, but also a paradoxical desire to articulate the relationship and linguistic correlation between physically tainted human and the metaphysically Divine archetype.

The deficiency and incapacity of human language to articulate desire for the divine is in an interactive play with the paradoxical nature of the poet-lover as a desiring subject. More than that, there is a mutual effect between it and the paradoxical nature of desire itself. Going back to Sidney's Astrophil and Stella, the paradoxical character of Astrophil's desire is rooted in the paradoxical nature of him being a poet-lover as indicated in Sonnet 60, especially in these lines: "Whose presence, absence, absence presence is; / Blist in my curse, and cursed in my blisse" (13-14). The previous line, ending with "tell me how I do", implies the authorial recognition of the paradoxical reality and the aspiration of an answer to this puzzling state of being he is in. Astrophil affirms the paradox as thoroughly existential: when he is "present,"

\footnotetext{
${ }^{11}$ All citations from Donne's Holy Sonnets are from The Divine Poems, ed. Helen Gardner. Oxford University Press, 1952.
} 
he is actually "absent" to Stella, and the converse is also true. He is living in a very perplexing and incongruous zone.

This confoundedly perplexing and problematic desire is in itself a paradoxical desire that not only echoes but also is ultimately derived from an unresolvable paradox of Reformed Protestantism itself. Reformed piety maintains to its believers that the God who is more intimate and "closer" to the self by dwelling inside that self is less possible to relate to the self since the Christian is overwhelmed by the sinful disposition of the "feeble heart", as Herbert's poem "Decay" pronounces. The Christian poet cries out:

But now thou dost thy self immure and close In some one corner of a feeble heart: Where yet both Sinne and Satan, thy old foes, Do pinch and straiten thee $[\ldots](11-14)^{12}$

Herbert's religious poet-lover subsists in a conflicted self, furnished with a devotional language that is exceedingly paradoxical. Identically, Astrophil's paradoxical subsistence is the inevitable consequence after he begins to inhabit the paradox he has linguistically created. A passionate and irrational yearning to reach far beyond his finite creative abilities could be the primary cause of his failure to discern the true natures and correlations of invention and imitation. As Stella is the object of his desires and the subject of his poetic creations simultaneously, Astrophil is impelled to make a choice between imitating her in his poems and focusing on himself and his own affections, a choice that unavoidably detaches his poetic inventions and passions even more from their derivation.

Gavin Alexander notes that the fifteenth-century reviver of Neoplatonism, Marsilio Ficino, one of the most influential humanist philosophers of the Italian Renaissance, elaborates the basic Platonic material usefully: "the lover engraves the figure of the beloved on his own

\footnotetext{
${ }^{12}$ All citations from Herbert's The Temple are from The English Poems of George Herbert, ed. Helen Wilcox. Cambridge University Press, 2007.
} 
soul. And so the soul of the lover becomes a mirror in which the image of the beloved is reflected. For that reason, when the beloved recognizes himself in the lover, he is forced to love him" (58). ${ }^{13}$ When Astrophil traps himself in this unnatural, paradoxical relationship, he also absorbs his desire into an obscurity, an intricacy where he is definitely rejected by Stella yet unable to cease desiring her. He pours out this involute paradox of desire at the end of Astrophil and Stella:

So strangely (alas) thy works in me prevaile, That in my woes for thee thou art my joy, And in my joyes for thee my only annoy.

(lines 12-14, Sonnet 108)

Indeed, the desire that is paradoxical for Sidney's speaker cannot be disjoined from the language. The paradoxes displayed by poet-speakers such as Astrophil appear at every point in the poetry, where the language by which the paradox is expressed compromises itself via the challenging of its own contention. Paul A. Marquis further argues that the text of the Sidneian Sonnets "contributes to its own deconstruction by inscribing the message of the incompatibility between the secular and the sacred worlds" (68). This is also verifiable in all other poets this thesis explores, including Spenser, Donne, and Herbert.

In some ways, it can be propounded that both Donne and Herbert implement the same paradoxical desire into their articulation of the divine love, or the desire for God. They also face the same problem, namely, the inability of postlapsarian human language to express such desire. In order to resolve the problem of expressing desire, a voice or texture that bears double meaning and is able to bridge the gap between the "Discord[s]" is critically needed. In Expostulation 19 of his prose Devotions Upon Emergent Occasions, Donne praises God's words as, paradoxically, the only means of expressing the "inexpressible texture, and

\footnotetext{
${ }^{13}$ See Ficino, Commentary on Plato's "Symposium” on Love, trans. Sears Jayne. Spring Publications, 1985. p. 57. Cf. Phaedrus, 255d: "[The beloved] does not realise that he is seeing himself in the lover as in a mirror" (Plato, Complete Works, ed. John M. Cooper. Hackett, 1997).
} 
composition of thy word" (411). There is an urge for a double voice or dual voice to diminish the conceptual distance between the desiring subject and the desired object in order to express the desire for the divine. In the beginning lines of the opening poem of The Temple, "The Dedication", Herbert suggests that the voice of his devotional poems is simultaneously God's and humans':

Lord, my first fruits present themselves to thee;

Yet not mine neither: for from thee they came, And must return. Accept of them and me, And make us strive, who shall sing best thy name. (1-4)

Thomas Ward comments that Herbert writes "directly into the paradox that, while God, the self-sufficient Logos, does not need the addition of man's voice [...] neither is man's voice simply an inert conduit or container for the divine Word" (142). The implementing of the dual voice is in correlation with the fundamental predicament of paradoxical desire. For Renaissance poets, there is a conceptual distance between bodily types, physical objects and the ideal essence in a Platonic sense; and there is an ontological and substantial gap between humans who are made in the Imago Dei and the Deity himself who is the perfect Divine archetype to be constantly imitated. Lastly, the distances mentioned above engender expressive and linguistic gaps due to which the desire to represent one for another becomes baffling. Poets gradually recognised since the Renaissance that conceit could be used as a tool to fill those gaps. According to Mazzeo, Renaissance poets saw conceit as an expression of the correlation between objects through universal analogy, since a more direct perception of things is blockaded by the observing subject. Naturally, in order to break those obstacles between conceptual and linguistic extremes, conceits are employed as "harmonic correlation between [...] knowable extremes, the act whereby the understanding discerns the correspondences between things" (32). Paradox as a form of conceit, involves "metaphorical or analogical 
correspondences" (The Routledge Dictionary of Literature Terms 31). ${ }^{14}$ In addition, the "correspondences" may seem paradoxical or extreme, but they are brought together by analogical thinking. Hence, the ultimate resolution of paradox is to use paradox to solve paradox.

Some would argue that Spenser moved beyond paradox for seeking reconciliation between "Discord[s]". Kenneth J. Larsen states that Spenser treats Petrarchan models with a smooth cadence and flow that "blurs the contrarieties to the extent that the distinction between the paradox's elements becomes confused and a kind of integration is suggested" (24). Partly agreeing with this postulation, I further argue that Spenser works the desire of the poet-lover into the discordant correlations yet does not separate the contraries. The basic "contrarieties" in Amoretti and Epithalamion are the antithetical inclinations of craving the physical beauty of the beloved and upholding the Platonic ideals. While the conflict induced from the simultaneous working of the two inclinations is reflected in sexual conflict, Spenser's resolution of paradox is on a certain level his resolution of sexual conflict. The satisfaction of desire evinces such resolution, and it is obtained by the poet-lover in the "sacred bond of marriage" - as noted by Reed Way Dasenbrock — in which there is no "rise" from the physical to the spiritual: "the proper kind of physical love is spiritual" (48). Seeing this from another perspective, the conflict fostered by the two intensively discordant desires of beauty-the spiritual and the fleshly as defined by Platonism — can only be satisfactorily resolved by a paradoxical union in which "Discord[s]" themselves are rightfully established as the proper vehicle of uttering paradox. Hence, the seemingly illogical formula of "chast desires" (line 8, Sonnet VIII, Amoretti) emerges. When the beloved woman the poet-speaker passionately desires "calme[s] the storme that passion did begin" (line 11, Sonnet VIII), it is indeed

\footnotetext{
${ }^{14}$ Conceits as metaphors used by Petrarch experienced resuscitation in Metaphysical poetry by poets such as Donne who "tapped deep springs of Petrarchism that flow from his love poems into his Holy Sonnets" (The Princeton Encyclopedia of Poetry and Poetics 1031).
} 
demonstrated-as well put by Don M. Ricks-that Spenser "makes Platonism serve Petrarchanism" (15). The Platonic ideals are upheld, and the discordant correlations remain.

Spiritual desire as conjoined and articulated by the "proper kind of physical love" proves the prerequisite of the incongruous yet undetachable linguistic connection between the bodily and the heavenly. In a way, early modern poets this thesis explores search laboriously for that "proper kind" of both desire and language by which contradictory extremes can be reconciled. How can fleshly love and earthly desire retain their place while their fundamental antithesis, spiritual and heavenly aspiration, is sought? As ardently Protestant poets, both Spenser and Sidney resolve the problem of paradoxical desire in religion. Spenser's speaker justifies his fleshly desire in the Christian ideal and "the sacred world of marriage" (Dasenbrock 46). Sidney's Psalmist David finds God in earthly and bodily realms through faith: “trust on heav'nly power, / Thou shalt have both good food and place" (lines 7-8, Psalm 37). ${ }^{15}$ According to Anne Lear, the Psalms had long been appreciated as "a repertory of 'proper' human responses" to the Divine being (227). This is markedly true for the Sidneys' Psalms. However, the literary endeavour to find "proper human responses" to the divine (along with all the meta-physics) in the expression of desire in order to resolve the problem of paradox is explicitly reflected in Donne's and Herbert's religious poems, in which the poets implement several other kinds of Christian paradoxes.

Like Spenser, Donne and Herbert adapt the Petrarchan paradox, with the "contrarieties" that are its core principle, into creating connections to Reformed Protestant themes and imagery. "[C]ontrarieties" or "Discord[s]" appear in the conceptual extremes such as life versus death, which are associated with the Christian religion. For instance, the implementing of Christian paradox is reflected in Donne's Holy Sonnet "Death be not proud" where the poet-speaker

\footnotetext{
${ }^{15}$ All citations from the Sidneys' Psalms are from The Sidney Psalter: The Psalms of Sir Philip and Mary Sidney, ed. Hannibal Hamlin et al. Oxford University Press, 2009.
} 
addresses death and enters into a communication based on the idea of resurrection. The proposition that "those, whom thou think'st, thou dost overthrow, / Die not" (3-4) is in itself paradoxical. The passionate objection or complaint against human immortality is displayed in the paradoxical utterance "Death thou shalt die" (14). This performance of paradox is all at once linguistic, conceptual, and theological. The desire that the Christian poets Donne and Herbert express is ultimately realised in the working of Christian paradox where the most religiously controversial actions of conjunctions and discordant correlations are to be found, and significantly, in sacramental poetics.

In this thesis's discussion of sacramental poetics, the word "sacramental" refers to Christian sacramentology, the theology of Sacraments. The Petrarchan and Neoplatonic conflict between spiritual love and physical desire is perceived in terms of sacramental pair. The Sacrament is the type or embodiment where the dual presence of Christ's incarnation, namely the mysterious union of his human nature and divine nature, is exhibited. Both Donne and Herbert articulate desire through a sacramental poetics inspired by the Eucharist by which the paradoxical dyad of body and soul, and the physical and spiritual love of the Christian lover, is conveyed through the elements and meaning in the Sacrament. The resolution of the paradox of desire is then found in and through the sacramental paradox, as the rightful response to the divine archetype. According to Sanders, Donne applies paradox as "a method of analysis", that is resolved in God:

The often heterodox and destabilized world of Donne's poetry is held together both by a transcendent and almighty Creator and by a Godlike poet who shows his power by enforcing conjunctions and exploring correlatives and analogies (198).

The endlessly conflicting and irreconcilable nature of physical versus spiritual desire as found in the Petrarchan lover is now considered to be sacramental "correlatives" and analogies of the incarnational truth, making the "contrarieties" conjunctive. The fleshly is not relinquished, but 
is applied within the sacramental rendition as correlative to the spiritual meaning in just the same way that the wine and bread are conjunctive and related to the blood and body of Christ. Hence, the sacramental paradox's capability to articulate and resolve paradoxical desire echoes Donne's understanding of the Sacrament as, in the words of Achsah Guibbory, "not only mysteriously connecting the body and spirit, but actually effecting grace" ("Donne, Milton and Holy Sex"110).

What Donne displays in articulating paradoxical desire, as a contiguous progression from Sidney's innovative Petrarchism and Spenser's application of Neoplatonism, is an idiosyncratic perception of the body-spirit correlation through the lens of Christian sacramentology. For him, the conceptual rejection of the body or the fleshly in favour of the soul or the spiritual is not only philosophically flawed, but also theologically erroneous. The concept of the pursuit of the bodily and of the spiritual as mutually exclusive is, for him, an essential delusion of both Petrarchan and Neoplatonic traditions. To reject the body is to deny completely and bluntly the truthfulness and goodness of materiality and physicality according to which, paradoxically, the meta-physical Christian truths of the incarnation and the resurrection are constructed. Moreover, these are exactly the two crucial theological doctrines that are commemorated in the Sacrament of the Eucharist. In the amorous poem "The Extasie" in Songs and Sonets, it seems that what obstructs love is precisely the disembodiment of the souls. Ramie Targoff finds that the expression of the relationship between body and soul in this poem is in association with the Aristotelian idea that the soul is inseparable from the body (57). For Donne, the ideal articulation of paradoxical desire is to be achieved through the recognition that the soul and the body are mutually dependant in their respective expressions:

Loves mysteries in soules doe grow, But yet the body is his booke.

And if some lover, such as wee, Have heard this dialogue of one, Let him still marke us, he shall see 
Small change, when we'are to bodies gone.

Targoff argues that the final lines of the poem "celebrate the ultimate indistinguishability of spirit from flesh once the soul is reincarnated" and that Donne suggests that humans turn to their bodies because they cannot live without them (57). Not in full agreement with Targoff's claim, this thesis argues that the distinguishability persists in the poem. Just as the two natures of Christ are united yet distinctive, the poem expresses the relation between the body and soul as a union yet at once also a distinction. In fact, Donne's poetical assertion is in itself theological, and, on the other hand, his doctrinal conviction of the Real Presence in the Eucharist resonates in his poetics in the principle that "the Discord of extreames begetts all vertues" (Paradoxes and Problems 21). In his Holy Sonnets, the spiritual and the fleshly desire of the Christian poet-speaker is performed in a metaphoric communion in which the two "contrarieties" are inseparably united. This echoes "contraryes meete in one" in the poem "Oh, to vex me", and resembles the Eucharistic ritual where two distinct objects - Christ's human nature and divine nature - come together in unity. The poem "The Extasie" is so complex that Ben Saunders argues, contrarily to Targoff and also to this thesis, that what produces the central paradox in this poem is that Donne "wants to affirm and deny the body" (143).

Perhaps a crucial question in discussing the articulation of paradoxical desire is that of where to locate the body. Michael Schoenfeldt comments that Donne initiates a "powerful admixture of psychological condition and bodily fluid" (Renaissance Transformations 148). For Donne, not only is the body fluid and capable of conveying divine truths, but also the nature of desire itself is fluid. The two - the body and the nature of desire - are inescapably and expressively linked together and find their most puzzling and intriguing meanings in the Sacrament, which in Donne's poems, as Robert Whalen points out in "Secular Verse of the Religious Man: Donne and Sacrament at Play" in The Poetry of Immanence, "permeates his perception and poetic experience" (59). The fleshly and the spiritual experience of the poet- 
lover, along with many other "Discord[s]" and disparate domains of early modern culture, suggest such types of realities that are essentially fluid and paradoxical. These realities are the same for Herbert, who also works through "correlatives and analogies" the significance of the Sacrament into an erotic formula that works in paradoxes, returning the earthly eros of postlapsarian humans to the sacred one. The paradoxical desire effected by the incarnational paradox of Christ, which claims to "subject the Logos to a body" (Whalen 59) in the sacramental performance as found in Donne's Holy Sonnets, is more explicitly presented in The Temple of Herbert, whose devotional dexterity is built on the same Word/flesh paradox at the centre of Christ's incarnation.

This thesis is divided into three chapters. Each chapter discusses two major works by respective poets, set up in two sections as a parallel or comparison. In Chapter One, I discuss the paradoxical desire of Sidney's Astrophil in Astrophil and Stella as demonstrating Petrarchism and the Petrarchan lover's enfolding in Neoplatonism. Astrophil's desire for Stella and his desire for Platonic ideals generates a struggle within himself. Then I explore Donne's amorous poems where he uses religious vocabularies to communicate erotic and sexual love, filling the gap between the linguistic extremes of the desiring subject and its object, establishing paradoxical unity through sacramental language. This chapter traces the continuum from Sidney to Donne in light of the Petrarchan lover's paradox.

Chapter Two considers Spenser's paradoxical body, and Philip and Mary Sidney’s Neoplatonic Psalmist. By his executing of Neoplatonism in his Amoretti and Epithalamion, Spenser obtains Platonic ideals through desiring the fleshly and physical beauty exhibited in his lover's body. This desire is eventually justified in Protestant marriage. In the Sidneys' Psalms, the Psalmist as a Neoplatonic lover searches within the earthly and physical realmswithin nature and his own body - to express his desire to imitate God and praise the Divine being. 
Chapter Three concerns Donne's and Herbert's expression of Christian desire in their sacramental poetics. In the first section of this chapter, I discuss Donne's religious poems, specifically the Holy Sonnets, where spiritual love is mediated through fleshly desire in sacramental poetics. The relationship between physical desire and spiritual love, and between the body and the soul of a Christian human, is comprehended through sacramental analogy. Comparably, in Herbert's The Temple, the internal and external components of religious desire reflect the sacramental theories in which the Eucharistic elements are believed to communicate their divine referents. The effective way to express his love for God, paradoxically, is to establish a spiritual justification for an affirmative embrace of sexuality, directing the sexual metaphors and fleshly desire in serving as a vehicle of Divine grace.

The paradox of desire and its diverse articulations in early modern poetry continue to provide literary critics with inexhaustible perspectives to interpret concepts and contexts that are not only pertinent to their contemporary philosophical and theological signification, but also to our own understanding and decoding of the world. The expressions of paradoxical desire, via the poetical and linguistic embodiments of Petrarchism, Neoplatonism, or sacramental poetics, reflect the universal authorial aspiration to translate the transcendental, whether that be amorous or divine, and thus never lose their intellectual and passionate impetus. 


\section{From Sidney to Donne, and the Petrarchan Lover's Paradox}

One of the most salient characteristics of Petrarchism in almost all Elizabethan sonneteers is their aspiration toward a nearly unattainable and extremely idealised woman (or on rare occasions, man). Petrarchism is a "strong poetics of desire", as Anthony Low points out in The Reinvention of Love, "of terrible longing for the absent and unobtainable" (12). The Italian Renaissance poet Petrarch expresses in his Canzoniere ongoing contests not outside of himself, but within himself. He articulates a passion and intensity that is complex and conflicting. In Sonnet 132, for example, he questions, "If it is good, whence comes this bitter mortal effect? If it is evil, why is each torment so sweet?" and laments "O living death, O delightful harm" (270). ${ }^{16}$ These contrasts and struggles eventually form paradoxes. The classic Petrarchan paradox is expressed through the juxtaposition of various contradicting extremes that are typified by the poet-lover who "burn[s] and freeze[s] like ice". The poet-lover experiences a kind of love that simultaneously gives him pleasure and pain. Within the paradoxical discourse of simultaneously burning and freezing, the Petrarchan poet-lover constantly seeks a solution for the baffling problem in which the pain of failing to indulge the fleshly desires and the satisfaction of comprehending the Platonic ideals reflected in the beloved move in circulation and affect him in a mutually incompatible manner. This is partly the result of the philosophical principle of Neoplatonism being blended with Petrarchism. Philip Sidney's sonnet sequence Astrophil and Stella mainly engages with this paradox: the Petrarchan lover enfolded in Neoplatonism.

\footnotetext{
${ }^{16}$ This citation is a page number from Robert M. Durling's English translation, Petrarch's Lyric Poems, which translates the rhyming quatrains into prose stanzas.
} 
However, more than developing the fundamental Petrarchan paradox, Sidney's Astrophil and Stella concerns itself with another kind of paradox, which I call the paradox of representation, or the paradox of poetic invention. Having failed to obtain the idealised woman through climbing the Neoplatonic ladder of love, the poet-lover searches inwardly for inspiration, and invents an image of his beloved in himself. The poet finds his existence perplexing and disconcerting:

I am not I, pitie the tale of me. (line 14, Sonnet 45)

The concept of paradox, as an expressive culmination of attempting to coordinate incongruent and contrasting extremes, can be inferred from the idea voiced in this line from Astrophil and Stella.

In this chapter, I argue that, as contiguous and continuous developers of early modern love lyrics, both Sidney and John Donne assume Petrarchism as a philosophical paradox of desire. In this complexity, the desiring subject, namely the poet-lover, obstructs his selfsatisfaction and as well the poetic representation of it by his own very subsistence. To put it in another way, the fundamental problem both Sidney and Donne find is that desire itself advances a supposedly insuperable obstacle when a human subject correlates with his object. Astrophil to some extent apprehends that the realism of his love for Stella clashes with "Vertue" as understood through Neoplatonism's theological relevance. For Sidney, a crucial predisposition of the paradoxical poet-lover is his growing awareness of his constraints and his readiness to embrace them. This idea is much more discernible in Donne's amorous poetry. In addition, this is more manifestly communicated through Donne's application of conceits as correlations between extremes. 


\subsection{Sidney's Paradoxical Lover in Astrophil and Stella}

Sidney's Astrophil and Stella was written in the 1580s and published in 1591. Like many of the Elizabethan sequences, it is principally an imitation of the Petrarchan sonnet sequence. Yet it is also an innovative variation of Petrarch. In Sidney's plot framework, a love relationship is staged, beginning with the lover Astrophil's attraction to the lady Stella's beauty, and moving through a variety of trials, sufferings, and conflicts to a conclusion where nothing is resolved. Sidney has Astrophil deride the typical principles and Neoplatonic rules of Petrarchism, mostly through an operation of convoluted logical inconsistencies, yet the Petrarchan principle of desire is still the source of his figurative language. Firstly, Astrophil establishes his consciousness of Platonic ideals as he repudiates "Vertue" in Sonnet 4, "Reason" in Sonnet 10, and "Truth" in Sonnet 11. These repudiations gradually reduce the scope of Astrophil's wit. By persuading himself that "the heavenly part / Ought to be king" in Sonnet 5 (lines 2-3), Astrophil emphasises his Platonic ideals, but in the same instant, he encourages the pursuit of amorous desire:

True, that on earth we are but pilgrims made, And should in soule up to our countrey move:

True, and yet true that I must Stella love. (14)

Astrophil realises that the reality of his desire for Stella is irreconcilable with "Vertue" (9) as it is apprehended through the lens of Neoplatonism's Petrarchan significance.

In Sonnet 25, by setting forth his amorous experience against the idealism of Plato ("wisest scholler") and the Neoplatonic ladder of love, Astrophil seeks to justify his desire for Stella. Astrophil uses the phrase "burne in love" (14) to describe his desire as affirmation of Vertue's beauty as he perceives it in Stella, who turns into spiritual Love incarnate: "Love of 
her selfe, takes Stella's shape" (10). ${ }^{17}$ Astrophil's fleshly desire is to Stella's beauty as the Platonist's spiritual desire is to Vertue, and it is the former correlation, according to Astrophil's postulation, that is the truest. Now a paradox rests in Astrophil's rhetorical transference of a higher, spiritual desire into a lower, physical embodiment in an outright reversal of the Neoplatonic chain. The desire for Vertue, in the Platonic sense, is unseen by Astrophil who confesses that he is not of the "Heroicke minde" (8) which is able to comprehend those "skies" (7) above. Hence, he brings transcendental, spiritual desire and Vertue down to his physical level. Consequently and paradoxically, it is unnecessary for him to ascend to any higher love. ${ }^{18}$ Then in Sonnet 35, Astrophil associates Stella with "perfection" (12), demonstrating again his configuration to blend "Vertue" with Stella and in so doing to validate his desire:

WHAT may words say, or what may words not say, Where truth it selfe must speake like flatterie?

Within what bounds can one his liking stay, Where Nature doth with infinite agree? (1-4)

Astrophil makes a declaration that, even though his poems might have the appearance of adoration for Stella, he is simply applying lofty and splendid language to pursue her as his poetic subject:

Wit learnes in thee perfection to expresse, Not thou by praise, but praise in thee is raisde:

It is a praise to praise, when thou art praisde. $(12-14)^{19}$

\footnotetext{
${ }^{17}$ Human souls as "flames" or holy fire (line 4) is a conceit that frequently appears in Renaissance poetry. One possible interpretation is that Sidney is making Astrophil misappropriate this "flame" conceit for irony as well as for creating paradox.

${ }^{18}$ Cf. Daniel Philip Knauss. "Love's Refinement: Metaphysical Expressions of Desire in Philip Sidney and John Donne". North Carolina State University, 1998. Knauss has a comprehensive study on how Astrophil brings the image of Stella down to his own ego. His thesis inspires my initial reconsideration of the articulation of paradoxical desire in Sidney's Astrophil and Stella.

${ }^{19}$ Moreover, the poem is saying that the language speaks itself ("truth it selfe must speake", line 2) and that Stella "raises" those words - they come out of her ("praise in thee is raised", line 13). Therefore, Astrophil is not merely applying the word. The relationship between Stella and the words is possibly more integral than that.
} 
According to Ringler, line 4 describes Stella as though being "a product of finite nature, [she] is goddess-like and therefore infinite" (472).

The paradoxical nature of Astrophil's desires firstly consists in his aspiring to spiritual gratification in Stella's "Vertue" and "Beautie", by attempting to characterise his feelings in accordance with the framework of Neoplatonism, while concurrently expressing his base physical desires. As this desire degenerates, progressively moving away from the spiritual and towards the physical, the paradoxical expression intensifies. Astrophil continues to express his amorous desire by means of Platonic topics as in the correlation between physical "Beautie" and spiritual "Vertue". He refers to Stella's eyes as "Vertue [...] made strong by Beautie's might" (2) in Sonnet 48 and identifies himself as the slave of his beloved as shown in Sonnet 47: "What, have I thus betrayed my libertie?" (1). The Neoplatonic depiction of his desire is repeatedly corrupted by his recurrent paradoxical allusions to it and to physical desire. The fleshly inclinations of his desire become increasingly obvious after Sonnet 46, where the desecration of spiritual desire is indirectly expressed under the appearance of conventional Petrarchan sonnet. However, the paradoxical nature of physical desire becomes more apparent from Sonnet 46 and Astrophil does not avoid giving verbal liberty to his carnal instincts. The tension in which the woman is both physically desirable and represents the epitome of spiritual virtue is typical of the Petrarchan articulation of love, while the discourse of desire for physical features denotes an attempt against the Platonic articulation of love. Sidney might be questioning the spirituality and transcendentality of love pronounced by Renaissance Neoplatonism by making Astrophil create paradoxical inference to physical desire. ${ }^{20}$

Sonnet 71 exemplifies Sidney's presentation of the paradoxical expression of desire in accordance with the Petrarchan convention. Astrophil experiences the tension between

\footnotetext{
${ }^{20}$ On another level, this can be seen as a discordant position towards the strict moral and religious precept represented by Puritanism of Elizabethan era. I will discuss this in more detail in Chapter Two in relation to Spenser's amorous poems and theology, and in Chapter Three in relation to Donne's religious poems and theology.
} 
pleasure and pain. The Neoplatonic paradox of wishing to indulge in fleshly desires and uphold Platonic ideals as reflected in the beloved woman is also presented, as the concept of "Perfection" (9) appears. Astrophil pronounces his apprehension of "Perfection" when he discovers "Vertue [...] best lodg'd in" Stella's "beautie" (2), which is the distinctive mechanism for Astrophil's Neoplatonic conception. Continuing the discussion of the Platonic ideas brought up in Sonnet 5 and Sonnet 25, Astrophil perceives Stella as inspired by "Vertue", and hence the distinction between her and "Vertue" is confusingly obscured. Instead of being rendered as a real person who reflects or, using Sidney's own phrase in A Defence of Poetry, "figures forth" $(25,33,54)$ Vertue, she almost is "Vertue". ${ }^{21}$ Inevitably, Astrophil is unable to differentiate his desire for those spiritually Platonic ideals from his desire for Stella in her fleshly "beautie". In Sonnet 71, the paradox is taken to the next stage where Astrophil observes from Stella's "eyes" (8), not exclusively physical desires, but those which come from her "inward sunne" (soul) and are engaged in chasing away the "night-birds" (7), which is a metaphor for "all vices" (5). Hence, conforming to Astrophil's philosophy of love, his desires ought to be cleansed and sanctified by her:

So while thy beautie drawes the heart to love,

As fast thy Vertue bends that love to good: (12-13)

The paradoxical nature of desire intensifies as the sonnet comes to the last line when Astrophil voices through the personified Desire his refutation of the "Petrarchan idealisation" of Neoplatonic love: “"But ah,' Desire still cries, 'give me some food.",22 Astrophil’s appeal for "food" for his desire is a plain rejection of the Neoplatonic ascension of the soul through love (Kalstone 117). This, I would argue, is the way in which Astrophil adopts the Neoplatonic

\footnotetext{
${ }^{21}$ Sidney explains "figuring forth" as "representing" (25), "counterfeiting” (25), "illuminat[ing] (33).

${ }^{22}$ Heather Dubrow comments that in this line Astrophil voices a view of desire that "rebuts the Petrarchan idealizations" of Neoplatonic love. See "The sonnet and the lyric mode". The Cambridge Companion to the Sonnet, ed. A.D. Cousins and Peter Howarth. Cambridge University Press, 2011. p. 40.
} 
principles but reverses them. Robinson suggests that Astrophil "knows about the Platonic ladder and even tries to climb it, but more often than not he stumbles at the second rung and falls" (193). Many of his falls are preconceived and purposive, as conspicuous results of his own gestures, as we have seen in Sonnet $25 .^{23}$

Astrophil does not emulate the course prescribed for the "right poet" in A Defence of Poetry in that, although he sets Stella up as "the divine" - an archetype of virtue- he does not undertake his imitative capacity in accord with the Platonic ideals that Stella embodies. ${ }^{24}$ Rather, Astrophil draws the image of Stella into his own subsistence by merging that ideal with his inventive image of her. In other words, by incorporating his idealised representation of Stella, he is able to mould it to his own subjectivity, claiming it as the source of his poetic invention and desire. Progressively he propels himself into a self-absorbed and self-obsessed peculiarity, which he expresses as a state of paradox. At the end of Sonnet 60, Astrophil displays the paradoxical nature of his desire as rooted in the paradoxical position of himself as a poet-lover:

[...] tell me how I do, Whose presence, absence, absence presence is; Blist in my curse, and cursed in my blisse. (12-14)

He recognises the paradoxical reality of his relationship to Stella and aspires for an answer to this puzzling state of being he is in. He then reaffirms the paradox as thoroughly existential: when he is "present," he is actually "absent" to Stella, and the converse is also so.

To some extent, Astrophil's poetic creation is an instrument by which Stella's love for him is to be apprehended; nevertheless, she is a channel for his aspiration of making that poetry

\footnotetext{
${ }^{23}$ Astrophil's intensive version of the paradox inherent in his Petrarchism as reflected in his inverted Platonism does not weaken but instead reveals the propositions he supposes to negate.

${ }^{24}$ The definition of the "right poet" in Sidney's A Defence of Poetry (26) is one aiming at a superior archetype (e.g. the divine creativity), which is in contradiction with Astrophil in Astrophil and Stella. Astrophil can be seen as a violation of the Defence's definition, since he frequently claims invention for himself.
} 
as well. Simultaneously desiring the poem and the woman inevitably sets both objects far above his grasp, because they are mutually irreconcilable and will ultimately overturn one another. Though Astrophil's aspiration for Stella's love for him is also his striving towards fashioning the poetry that he expects will fetch her to him with all its "Vertue" and "Beautie", it is also his growing and escalating recognition of the unattainability of both objects. Going back to lines 13-14 of Sonnet 60, quoted above, we see it becomes difficult to discern the realness of Stella as Astrophil strives to invent her "presence" in his poetry. Her aesthetic presence rests so tightly on her real "absence" that the contradistinction between poetry and reality evanesces from his perception.

In some ways, the essential paradox is found in Astrophil's acknowledgement of the poet-lover's subjectivity, and the perplexity and confusion that subjectivity advances in him. And this recognition as a poet-lover naturally subsists in his self-knowledge, which, according to Sidney, is not only stimulated by poetry itself, but is also connected expressively to what he terms in the Defence the "divine essence" of humans (28). Sidney insists in the Defence that the poet ought to be engaged in "singing the praises of the immortal beauty: the immortal goodness of that God" (69); and he criticises the deficiency of many writings produced by authors of what he perceives as defective Petrarchan imitations that "come under the banner of unresistable love" (69). Following these arguments is his conclusion that the unsettled error of them is their lack of "forcibleness or energia" (70). The concept of energia and the ancient rhetorical principle of "forcibleness" are some of Sidney's most frequently used poetic tools. According to Perry and Stillman, the concept of energia was discussed at a theological level by both the early Church Fathers and the Renaissance humanists including prominent Protestant theologians (331). The Word, energised by the Holy Spirit, "has power to effect metanoia", which is understood as the "purposeful change" of humanity, a spiritual renewal of one's life (331). Sidney brilliantly adopts this idea to elucidate the changing power of poetry. 
For him, in one respect, the poet's "forcibleness" in guiding readers to "Vertue" should be acknowledged, acclaimed, and honoured.

As mentioned above, in the Defence, Sidney speaks against Petrarchan sonnets that are faulty imitations of desire, and against those that do not model an invention that has originated from the wit and nature of the true poet himself as he understood it. Already in Sonnet 15, the poet-lover criticises conventional Petrarchism:

You that poore Petrarch's long deceased woes, With new-borne sighes and denisend wit do sing;

You take wrong waies $[\ldots](7-9)$

It could perhaps be argued that Astrophil and Stella was written in response to the problem Sidney noticed in Petrarchism and was postulated to rectify and reform the Petrarchan love lyric. For Sidney, desire is far more complicated and poetry that represents it should at the same

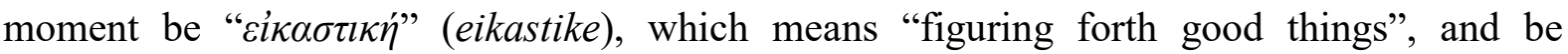

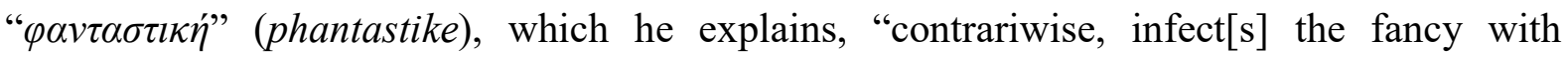
unworthy objects" (54). So far, Sidney seems to have followed the conventional articulation of Petrarchan paradox. However, he breaks away from classic Petrarchism in that he suggests that

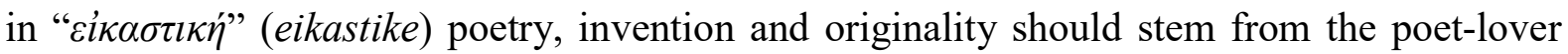
himself, not be acquired by looking at others outside of him. In Sonnet 1, the beloved woman is given a voice, interrupting the masculine monologue, advising the poet to look for invention within himself: “'Foole,' said my Muse to me, 'looke in thy heart and write”" (14). Stella wants him (or he wants Stella to want him) to stimulate Invention from himself. ${ }^{25}$ Astrophil's disconcertment at imitation and "Invention" is announced in this sonnet. His wandering from

\footnotetext{
${ }^{25}$ Contrasting Dante and Petrarch, who were Roman Catholics, this perspective of Sidney might be an influence of Protestant theology, particularly Calvinism, responding to which the ideal poet can be interpreted as an "elect" who individually speaks to God, "disdaining to be tied to any subjection", and has the right of being "lifted up with the vigour of his own invention, doth grow in effect into another nature, in making things either better than nature bringeth forth, or, quite anew, forms such as never in nature" (Defence 23).
} 
craving and yearning for the imitation of Platonic ideals will finally lead him to desperation. This journey begins in that his cravings contradict his principal self-conceit as he reckons himself the sovereign of illusory poetic ideals. His illusion is that he is not an imitative but an inventive poet who has no derivation apart from his own intelligence:

Oft turning others' leaves, to see if thence would flow Some fresh and fruitfull showers upon my sunne-burn'd braine.

But words came halting forth, wanting Invention's stay, Invention, Nature's child, fled step-dame Studie's blowes, And other's feete still seem'd but strangers in my way. Thus great with child to speake, and helplesse in my throwes, Biting my trewand pen, beating my selfe for spite, 'Foole,' said my Muse to me, 'looke in thy heart and write.'

The paradox is induced from one of the general propositions of the sonnet sequence, the internal movement in which Astrophil detests and despises almost everything external to himself, and from his understanding of his poetic facilities moving toward an uncontaminated "Invention". His inward attention to his "heart" (14) to search for inspiration-allegedly in his amorous desire for Stella - also propounds a gesture in the contrasting direction of the Platonic lover's going upward away from the physical toward the mind and the spiritual.

Throughout the sonnet sequence, the invention of Platonic ideals is sought and desired by the poet-lover, which consequently engenders his energia. Moreover, another invention can be clearly seen, which is the artful imitativeness founded on the poet-lover's own wit. The poetic compromise between the two inventions produces the paradox for Astrophil. Thus, the potency of Astrophil's desire to fully apprehend ideal love both in the aesthetic realm and in reality impedes his domination over mimetic invention. By maintaining the representation of Stella in himself, Astrophil's desire is constantly dictated and corrupted by the "forcibleness" of his own imaginative and fantastic mind. Unwilling to abandon the ideal of his self-governing invention, he keeps being brought back to the real Stella who rejects him, instead of the divine idea of her-his " $\varphi \alpha v \tau \alpha \sigma \tau \imath \kappa \eta "$ " (phantastike) Stella—in which realm his advances are accepted. 
For Astrophil, unhappily yet unavoidably, it is unacceptable that Stella is beyond his grasp. In this never-ending existential conflict, he comes to the ultimate solution to this paradoxical problem, as can be found in line 9 of Sonnet 82: he reaches a state where he is "full of desire, emptie of wit". The paradoxical nature of the expression of his desire transforms into another level of absurdity as he turns to simple innocence and purposely-artless ignorance as an apology for his struggle. As an instrument of inventive writing, this state is virtually unforced or impulsive in nature. On one level, it can be interpreted as sleep, but on another, as death. For Plato, sleep is related not only to death, but also to some sort of pre-existence of soul:

Death is one of two things - either death is a state of nothingness and utter unconsciousness, or, as men say, there is a change and migration of the soul from this world to another. (Plato, Apology 40c-e, trans. Jowett) ${ }^{26}$

I would argue that, by assuming the state of deadly sleeping or of "living-die", Astrophil has been attempting to embrace the dream reflection of Stella as his own reality. Bearing this idea of "living die" in mind, we see more patently why the paradox lies essentially in the poetlover's own existence. To be more specific, I am arguing that a desiring person is a paradoxical person. In other words, the state and condition of the subject who desires is inescapably that of a paradoxical subject. Quoting Catherine Bates, "[t]he 'I' experiences both the negative state of not having something and the positive state of yearning for that thing" simultaneously; the poetic involvement "paradoxically both does and does not seek satisfaction" (108). In fact, Astrophil's existential paradox has already been voiced as early as in Sonnet 6. In that Sonnet, though he claims to dismiss the discourse in Petrarchan convention where the poet-lover speaks "Of living deaths, deare wounds, faire stormes and freesing fires" (4), it is impossible for him

\footnotetext{
${ }^{26}$ Regarding the sleep-death correlation, see also lines 9-10 of Donne's poem "Womans constancy": "So lovers' contracts, images of those, / Binde but till sleep, deaths image, them unloose?"
} 
to discard it, since as a poet-lover, he has to adopt this discourse constantly in his pursuit of Stella.

Trying to seek satisfaction in the paradoxical living-death state, Astrophil's artistic self is relieved just for a while, and greater troubles present themselves shortly after he turns his focus to the dream-reflection itself. As can be discovered in Sonnet 38, the image of Stella, being the reality in whom ideal perfection exists, surpasses Astrophil's potentiality to control; hence, the poetic scheme of inventively and imitatively producing mimetic art is questioned:

The first that straight my fancie's error brings

Unto my mind, is Stella's image, wrought

By Love's owne selfe, but with so curious drought,

That she, me thinks, not onely shines but sings.

I start, looke, hearke, but what in closde up sence

Was held, in opend sense it flies away (5-10)

Exhibited as nothing but a shadow, Stella's very existence is contradicted and negated by Astrophil's endeavour to obtain sentient, fleshly, and physical penetration of her. Consequently, the experience of converting her into an idol overturns Astrophil's fanciful hope of possessing Stella. The foundational stimulus of this paradox lies also in the word "unkind" in line 14 of this sonnet:

I, seeing better sights in sight's decay,

Cald it anew, and wooed sleepe againe:

But him her host that unkind guest had slaine. (12-14)

Here Astrophil describes himself as Stella's "host", while Stella is portrayed by him as an "unkind guest" by whom he was slain. It is not difficult to comprehend that slaying one's host is an "unkind" action for a guest. However, according to the historical nuances of the word given by the $O E D$, the word "unkind" has the denotations of being "foreign, strange", or "not in accordance with the natural course of things". The indicative ambiguities of this word "unkind" insinuate the root of Astrophil's paradoxical desire. By implying the "unnaturalness" of Stella's image, the word tells that Stella is uncompassionate and unsympathetic to him, not 
because she keeps escaping from Astrophil's pursuit, but instead, because - as an "unkind" guest - she is not in accordance with the natural course, since she is merely Astrophil's

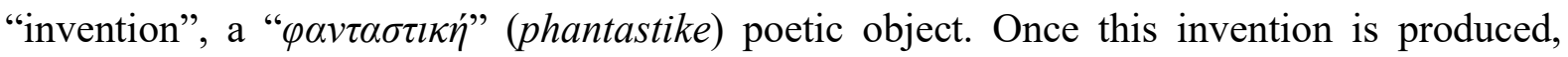
Astrophil traps himself in this unnatural, paradoxical relationship. The "Stella" he desires now is no longer made merely by the individual site of his own "mind" (6), but wrought by "Love's owne selfe" (7). This tacit correlation between self-love and self-inspiration eventually reveals the paradox spawned by self-absorption in Astrophil's desires.

Sidney claims in the Defence: "our erected wit maketh us know what perfection is, and yet our infected will keepeth us from reaching unto it" (25). This statement leads to the reasoning that the paradoxical desire of the poet-lover is found in the baffling reality of this wit-will parallelism - the correlation between the intellectual craving of imitation of the Platonic perfectness, and the earthly impulse which has contaminated every passion. Perry and Stillman explain:

History is conceived in unmistakably Christian terms as fallen. In turn, poetry's energizing power over the (infected) will in moving it toward the virtues that the (erected) wit apprehends imparts to fiction-making real agency in remediating (at least in part) the effects of the Fall. [...] Sidney's literary undertakings engage tightly with a line of early modern meditations [...] about the causative power of words to imitate the Word. For Sidney [...] imitation assumes its ultimate authority (directly or indirectly) from the desire to imitate that which is godly, as an imitatio Christi - that ultimate incarnation of truth authorized by the body and the Passion of the crucified Christ. (329-330)

For Astrophil, Stella is the "Word", the Author and the true Poet he endeavours to imitate in a degenerate manner. Though claiming to perceive her as a virtuous subject, he is not capable of characterising her with a congruous configuration since - as a paradoxical poetlover-he inherently negates every figuration in a representative sense. Astrophil is reluctant to perform those Platonic ideals even though he is able to comprehend them. This active peculiarity was not clearly communicated in conventional Petrarchism, yet it is one of the most 
distinguishing characteristics of Sidney's sonnet sequence. Trapped in this paradox, Astrophil keeps seeking to go back to the discursive machination of Sonnet 1 where he seems to maintain the full authority over "Invention". However, toward the end of the sequence, we can see that Astrophil gradually corrupts himself by his own euphuism, and becomes imprisoned in his own feverishness. As a poet-lover, Astrophil fails to find the instrument by which he can climb the Platonic ladder. Therefore, he descends into the quandary of "Tragedie" from where he declares in reasonable sincerity, as found in Sonnet 45, that this would be the denouement of every poetlover who ventures to desire:

Then thinke my deare, that you in me do reed

Of Lover's ruine some sad Tragedie:

I am not I, pitie the tale of me. (12-14)

I suggest from the above pronouncements that Sidney attempted in Astrophil and Stella to progress the system and manner of articulating desire by revealing the deficiency of conventional Petrarchism. For him, "poore Petrarch's long deceased woes" (Sonnet 15) are too constrained for articulating the paradoxical nature of desire as is found in Astrophil's rhetoric, in which he concurrently aims for ideal love and unavoidably yet realistically correlates that to fleshly love. What Sidney tries to describe is an uncomfortable and problematic poet-lover, who strives to capture and apprehend the Platonic ideal of love into his own poetic invention by integrating them into his debased and corrupted trajectory, resulting in the subject "I" reversing and focusing awkwardly back on himself. In other words, he embarrassingly and unreasonably struggles to transform ideals themselves into realities, which is not easy to achieve since ideals are veridical exclusively in their own frame of philosophical (and theological) reference. Belonging essentially to the other realm of revelation and discourse, those ideals constantly remind the makers of poetry that, as the Maker of all creations demands His worshippers to comprehend the incarnated sacred Truth in the fashion of symbolic façade and sacramental types (considering the Calvinist interpretation of the Eucharist), so poet-lovers 
must not confuse the Truth with symbolism when grasping it into this realm of expression. For John Calvin, who tremendously influenced Elizabethan theological and literary thinking, especially on sacramental doctrines, the name of things figured by metonymy can be transferred to the sign. ${ }^{27}$ Yet, one may never take the thing as realistically and physically the same as that it signifies. Symbolism is informative and didactic to the extent that symbols are received as what they are; however, one ought not to continue assuming the theatrical façade once the drama ends. Once a poet fails to do that perfectly, confusion, perplexity, and paradox creeps in. It is extremely difficult for a poet who writes in the Renaissance Neoplatonist context to maintain the potentiality of captivating the ideal and the physically real concurrently. From this perspective, I say that the problem of desire generated by the distance between the ideal and the physical in Astrophil and Stella remains unsolved.

\subsection{Donne's "Discord of extreames" in Songs and Sonets}

For Donne, desire is inherently paradoxical, as it is for Sidney's Astrophil; consequently, the articulation of desire is only realisable when the desiring subject (poet-lover) embraces sexuality and fleshly passion that is directed to a Platonic ideal end. Hence, in Donne's poetry, the implementing of conceits — comparisons between disparate objects-becomes the peculiar means by which fleshly desire and the desire to imitate and represent the divine archetype can be reconciled and integrated. The problem fostered by Petrarchism is that the oppositional and dualistic pattern, in which love for body and love for soul are always portrayed in a mutually exclusive way, inevitably generates paradox. Venturing to integrate and harmonise the seemingly opposing desires and the dialectical powers, Donne tries to solve this problem and

\footnotetext{
${ }^{27}$ Calvin writes in his commentary on 1 Corinthians 11:23-29, "Why should we not maintain that there is here a similar instance of metonymy, and that the term body is applied to the bread, as being the sign and symbol of it? [...] Here I reply that the name of the thing signified is not applied to the sign simply as being a representation of it but rather as being a symbol of it by which the reality is presented to us". See Calvin, Commentary on Corinthians, trans. Rev. John Pringle in 1848. Christian Classics Ethereal Library, 2005.
} 
break the obstacles between "extremes" through evincing desire from a Christian Platonist perspective.

The amorous poem "The Canonization", for example, can be read as a metaphor for the analogous desiring relationship between Christ and the Church. Donne starts with acknowledging both the desire for the infinite and the desire for the finite, and confirming the intimate analogy between desiring both human and divine. Reading this poem in light of Christian Platonism, all physical realities including fleshly or bodily desire can be seen as sacramental types shadowing and reflecting the heavenly truths and ideals. In the third stanza of the poem, the religious images of the "dove", "Phoenix", and "Eagle" demonstrate this metaphor of desire and paradox in particular:

And wee in us finde the'Eagle and the dove,

The Phoenix ridle hath more wit

By us, we two being one, are it.

So, to one neutrall thing both sexes fit. (22-25)

In the immediate context of the love poem, the male lover and the female beloved are represented as the "Eagle" and the "dove" respectively. Based on Donne's sermons and according to Christian iconography, the eagle and the dove denote opposites that are reconciled so that redemption can be realised. The eagle and the dove symbolise respectively the masculine and feminine essences, the antithetical characteristics of aggressiveness and gentleness. The significance of these contrasting traits unified in one is shown in two aspects. First, it presents Donne's theology that God declares both virtues in desiring man to reconcile with Him, either by approaching him as a "Dove" bringing "peace" or as an "Eagle" to devour him (VIII 123) ${ }^{28}$ Likewise, Donne's figurative portrayal of human desire for God's presence integrates elements of both the eagle and the dove: "God hath given you the wings of Doves,

\footnotetext{
${ }^{28}$ The Sermons of John Donne, ed. George R. Potter and Evelyn M. Simpson. References to Donne's sermons include volume and page references in parentheses.
} 
and the eyes of Eagles to see him now, in this place [Church]; If in returning from this place, you returne to your former wayes of pleasure or profit, this is a breaking of those Doves wings, and a cieling of those Eagles eyes" (VII 347). The expression "wee in us finde" (22) signifies the conceptual union of the eagle and the dove into one single emblematic show and reveals the desires of the lovers transferring toward unity. The next two lines display the other aspect concerning the meaning of the masculine and feminine principle being united in one:

Wee dye and rise the same, and prove

Mysterious by this love. (26-27)

The phrase "dye and rise" connotes resurrection in which the lovers' relationship becomes a paradox of desire.

Reading this poem as an audacious conceit for the analogous desiring relationship between Christ and the Church, Donne's rationale will be much more clearly understood. The Biblical pattern of the Church as the Bride of Christ confirms this analogy of marital union and love. Donne would be familiar with the Apostle Paul's phrasing concerning the relationship between Christ and the Church, that "they two shall be one flesh". ${ }^{29}$ Ideas such as these are the motivations by which Donne uses religious language to communicate erotic concepts, and implements theological expressions and vocabularies to convey the sexual and profane. ${ }^{30} \mathrm{By}$ means of seemingly contradictory conceits, the poet attempts to diminish the conceptual distance between the earthly and the heavenly. In lines 26-27, rising from orgasm, implied by the word "dye" (26), is compared with the death and resurrection of Christ, both of which prove the "Myster[y]" of love, the former physically while the latter theologically. The mystery of love expressed in those lines undoubtedly indicates the mystery of marriage also, as it reveals

\footnotetext{
29 "For this cause shall a man leave father and mother, and shall cleave to his wife, and they twain [two] shall be one flesh. This is a great secret, but I speak concerning Christ, and concerning the Church" (Ephesians 5:31-32). Cited from 1599 Geneva Bible. Tolle Lege Press, 2006.

${ }^{30}$ On the other hand, Donne employs sexual discourse to express divine love, typically in the Divine Poems, which I will discuss in Chapter Three.
} 
the relationship of Christ and His Church. Interestingly, the perfect regenerated union is unsexed even though it incorporates both sexes: "So, to one neutrall thing both sexes fit" (25). In order to express desire, one of the most separated and fundamental extremes in human beings - sexes - are diminished by the poet. Accordingly, a turning point from earthly and physical love to divine canonization is provided.

The analogy and parallelism of the lovers in "The Canonization" to their heavenly pattern of love manifests at the end of the poem as they finally achieved sainthood. The words "thus invoke us" (37) indicate that this corresponding desiring relationship would serve as a pattern for other lovers desiring ideal unity with God, yet concurrently within themselves:

And thus invoke us; "You whom reverend love Made one anothers hermitage; (37-38)

Ironically, in filling the gap between the linguistic extremes of the desiring subject and its object, the lovers' desiring relationship becomes another Platonic ideal to be imitated by others. In one of his sermons, Donne encourages Christians to appreciate saintly people in the Bible and to imitate them: "God proposes to thee in his Scriptures, and otherwise, Images, patterns, of good and holy men to goe by" (IX 76). In the last two lines of the poem, we see what might be called an inversion of the Platonic postulation. The universal observes downwards, "beg[ging]" (44) to obtain the "patterne" (45) of the particular (yet the exceptional) - the lovers' desiring relationship — instead of letting the lovers in their own metaphysical position endeavouring to discover the "patterne of [their] love" (45) in an extensive range of generalised types and correlations such as "Countries, Townes, Courts" (44). ${ }^{31}$

Lastly, as the lovers evolve together into the position of being canonized and sanctified in accord with the glorious divine archetype, so their desire and passion as that between Christ

\footnotetext{
${ }^{31}$ According to C. A. Patrides's note, the word "patterne" is a technical term in Neoplatonic thought for Ideas in the mind of God.
} 
and His Bride develop into an archetypal example for the devoted congregation here on earth. It is not that ambiguous since, for Donne, the Church Triumphant manifests the "patterne [...] for this holy manner of praising God" that the Church Militant ought to aspire to for the realisation of her own sanctification and glorification (VIII 56).

However, this final line concerning the "patterne of our love" does not completely diminish the distance between the tangible and substantial, and the abstract and essential. In other words, the gap between linguistic and conceptual extremes is yet to be fulfilled; hence, the desire of representing and imitating is still obstructed and inescapably trapped into the paradox. Since the pronouncement of any concepts of "patterne" and form is fundamentally abstract and meta-physical, the presentation of it is inevitably connected with desire as a metaphysical copy (in a Neoplatonic significance), or a philosophical abstraction. As discussed above, the lovers in "The Canonization" in their corresponding desiring relationship experienced a certain kind of evolution and development before achieving that canonization. Obviously, the noun "canonization", which is made up of the verb "canonize" with the adding of the suffix "-ation", designates a process or operation. Donne articulates this process as some kind of "extraction" as in the art of alchemy, which was very popular in Renaissance Europe. In the last stanza of the poem, the abstraction of desire is displayed as an extraction seen in the eyes of the lovers:

You, to whom love was peace, that now is rage,

Who did the whole worlds soule contract, and drove

Into the glasses of your eyes

So made such mirrors, and such spies,

That they did all to you epitomize $(39-43)^{32}$

\footnotetext{
32 The word "contract" in line 40 is "extract" in other editions, denoting alchemical transformation. The whole world's essence is extracted by the lovers into each other's reflections in their own "eyes", conceived as "glasses" and "mirrors".
} 
In joining the "patterne" of love and desire with the Neoplatonic ideal and the undertaking of abstraction, the seemingly insuperable impediment advanced by desire conversely transmutes into a paradoxical obstruction that neither earthly desire nor the heavenly one could represent and enunciate accurately. The underlying problem remains unsolved unless the rhetorical abstraction is to be evaded.

Donne attempts to untangle this incongruity more clearly in another poem, "Loves growth", where the notion of alchemical extraction is engaged more explicitly:

But if this medicine, love, which cures all sorrow With more, not onely bee no quintessence, But mixt of all stuffes, paining soule, or sense, And of the Sunne his working vigour borrow, Love's not so pure, and abstract, as they use To say, which have no Mistresse but their Muse, But as all else, being elemented too, Love sometimes would contemplate, sometimes do.

Here the poet honestly admits his love to be no "quintessence" (8), which according to the $O E D$ refers to "the most essential part of any substance, extracted by natural or artificial processes". By forthrightly repudiating love as "not so pure, and abstract, as they use / To say" (11-12), he renounces the Platonic principle of characterising love in order that the abstracting of it can be eluded. As a matter of fact, by addressing love as "mixt" (9) and "elemented" (13), the poet argues that love cannot be abstracted, but, rather, grows in an elemental process. In this process, his love would "sometimes [...] contemplate, sometimes do" (14). Hence, it is not "greater, but more eminent" (15).

Consequently, he is able to compare love to "Spring" (16), as analogising the transcendent to the earthly. This conceit does not appear banal, since what Donne tries to reveal here is far more than the reality of "loves growth" that is to be literally and figuratively induced by the season. Donne explores in this poem whether desire can be persistent and yet growing and springing, whether it is possible to comprehend change and transformation without 
inevitably incorporating decomposition and corruption. He continues his elaborate conceits, analogising the growth of love to "Starres" (18), "blossomes" (19) on a tree, and ripples in "water" (21-22):

And yet no greater, but more eminent,

Love by the Spring is growne;

As, in the firmament,

Starres by the Sunne are not inlarg'd, but showne,

Gentle love deeds, as blossomes on a bough,

From loves awakened root do bud out now.

If, as in water stir' $d$ more circle bee

Produc'd by one, love such additions take,

Those like so many spheares, but one heaven make

The poet comes to the culmination here in line 23 . Recognising the tension and extremes between longing for constancy and yearning for change, he understands that what he really desires is - using the phrasing in The Second Anniversary — the paradoxical "kind of joy [that] doth every day admit / Degrees of grouth, but none of loosing it" (495-496) ${ }^{33} \mathrm{He}$ desires to possess this "joy" in the unification of the experience of fleshly love and the projection of heaven at the same time. Trapped into his own subsistence as a paradox, not being able to obtain the instability and the infinity of his desire simultaneously, he also, like Sidney, turns inward for solution. Now for the poet-lover, his amorous desire is nevertheless a singular actuality to be pronounced in a physical, tangible discursive manner that is capable of composing the essentiality and the centre of his predisposition. That one and single actuality is his beloved, the object in the other extremity that he is craving for, the unmoving ideal entity around whom all other frameworks - either physical or seasonal — convert accordingly:

For, they are all concentrique unto thee,

And though each spring doe adde to love new heate,

\footnotetext{
${ }^{33}$ Cited from John Donne: The Complete English Poems, ed. C. A. Patrides.
} 
No winter shall abate the springs encrease. $(24-25,28)$

Realising the paradoxical nature of his desire, which is composed in an inconsistent and contrasted realm, the poet has to dissolve the abstract. He has to reconcile the two extremesthe ideal and the physical reality-into one unitary interrelation in order to justify the incongruity. Donne's defiance of conventional Petrarchism is evident in this poem in lines where he straightforwardly denies love as "not so pure" (11). Yet, the maintaining of the paradoxical surmises and perplexing complications proves that the effect of the Petrarchan discourse is still there.

For Donne, it is never simply Petrarchism or anti-Petrarchism. As Heather Dubrow points out, he attempts to "bridge" the two (223). Refusing to remain in the original Petrarchan discourse that fails to achieve the poetic representation of his desires, he seeks to balance the Platonic and the anti-Platonic. Instead of viewing amorous desire in terms of perfect satisfaction or complete frustration, he aims toward the concurrence and correlation of the negative and the positive facets of desires. The poem "Negative love" clearly shows this attempt. In the beginning of this poem, Donne shows his occasional inclination toward the Platonic direction of love, yet he identifies that the "negative" way-the way of descendingis paradoxically the way of ascending:

$$
\begin{aligned}
& \text { I never stoop'd so low, as they } \\
& \text { Which on an eye, cheeke, lip, can prey, } \\
& \text { Seldome to them, which soare no higher } \\
& \text { Than vertue or the minde to'admire, } \\
& \text { For sense, and understanding may } \\
& \text { Know, what gives fuell to their fire (1-6) }
\end{aligned}
$$

Donne's speaker deliberately relinquishes the multiple categorically disparate sources of desire previously exposed by Sidney in composing Astrophil's Petrarchan desire toward Stella—her "eye, cheeke, lip", and her "vertue" and her "minde". Sidney and Donne employ bodily elements in relation to heavenly desire in different ways. The physical beauty of Astrophil's 
beloved is always highlighted via argumentative competitions with gods and goddesses, as can be found in Sonnet 52 in Astrophil and Stella:

A STRIFE is growne betweene Vertue and Love, While each pretends that Stella must be his:

Her eyes, her lips, her all, saith Love do this,

Since they do weare his badge, most firmely prove. (1-4)

The bodily elements in Stella's face, for Sidney, are the very reflection of "perfect beautie" (line 2, Sonnet 77), which would direct the poet-lover toward the Platonic "Vertue". However, Donne declares in "A Valediction Forbidding Mourning" that love that resides in physical elements should be considered as belonging to "dull sublunary lovers" (13). It is, therefore, inferior to the love he and his lover possess:

But we by a love, so much refin'd, That our selves know not what it is, Inter-assured of the mind,

Care lesse, eyes, lips, hands to misse. (17-20)

For Donne, the predetermined apprehension of the lover's "eye, cheeke, lip", and the Platonic "Vertue" that is reflected in it as the two separate extremities of desire's derivation, must be renounced. Otherwise, the desire to gain concurrently both a physical, sensual perception of love, and the spiritual, meta-physical appreciation of it would be hindered.

The poem "Negative love" continues to elucidate that the love that can comprehend perfection is one that is "silly" - unsophisticated, simple, plain — and therefore definitely not witty:

My love, though silly, is more brave,

For may I misse, when ere I crave,

If I know yet, what I would have. (7-9)

Here the critical principle that Sidney establishes in Defence and conveys through Astrophil and Stella, that "our erected wit maketh us know what perfection is" (25), is seriously challenged. The supposition of the desiring subject of knowing oneself is paradoxically 
collocated with the insistent proclamation that the poet-lover actually knows nothing, and thus wants nothing:

If that be simply perfectest

Which can by no way be exprest

But Negatives, my love is so.

To All, which all love, I say no.

If any who deciphers best,

What we know not, our selves, can know,

Let him teach mee that nothing; This

As yet my ease, and comfort is,

Though I speed not, I cannot misse. (10-18)

The wanting of "nothing" is a desire that is itself paradoxical. The operation of aspiring and yearning is one that aims toward a positive object. Yet now that focal object is constructed and negated at the same instant. In some ways, both Sidney's Astrophil and Stella and Donne's Songs and Sonets can be interpreted as poetic presentations of the theological consequences of the predicament of the poet-lover as postlapsarian man, whose object of amorous desire is inevitably devised and constructed according to the fleshly need and self-absorption of the subject whose will is "infected". ${ }^{34}$ Hence, the positive object of desire becomes an obstacle to desire's satisfaction. The "nothingness" that Donne tries to explore in this poem is not something of an absence or of a discursive manner of expressing cynicism; rather, it is "the notion of the impossibility of knowing or defining love perfectly" (Zickler 28). The subsistence of the desiring subject as a knowing subject obstructs self-knowledge itself, which is an unfortunate situation where love is no longer available to be known or be theorised:

If any who deciphers best,

What we know not, our selves, can know,

Let him teach mee that nothing [...] (14-16)

\footnotetext{
${ }^{34}$ Sidney's claim in Defence, "our infected will keepeth us from reaching unto it [perfection]" (25).
} 
For Donne, in order to overcome this plight, all kinds of aspiration-whether intellectual, sexual, or poetical — as desire must be reconstructed through the discursive negation of desire itself, and through the harmonising and resembling of the "[dis-]infected" (purified) will with the divine will. In other words, since every definition of love associating with its object positively is inadequate, the satisfactory elucidation of the "simply perfectest" love (10) can only be constructed indirectly, with regard to what it is not. Hence, the poet says of his love that it "can by no way be exprest / But Negatives" (11-12). Accordingly, the positive object of desire is counterbalanced by its contradiction, the negative one.

For Donne, this idea of contrasting and juxtaposing positive and negative desire is intensely comprehended and analogously conveyed in his handling of the comparison between the concepts of life and death. In order that the obstacle to desire's satisfaction be surmounted, the radical conceptual extremes of life and death should be firstly corresponded and communicated so that some sort of essential unity can be achieved. In the beginning of his poem "The Paradox", he declares that the absolute subjectivity of desire hinders the very potentiality of the lover's speaking of its immediate reality in his own understanding. The speaker states that the actuality of positive love is not available to be claimed by simply reflecting on its unalterable reality in the past:

Hee thinkes that else none can or will agree, That any loves but hee: I cannot say I lov'd, for who can say

Hee was kill'd yesterday. (3-6)

Perfect love is the position that is current, existing, and present. Yet it is correlated with death, because it overwhelms both the object and the subject completely. It is a prevailing-living state. Lovers are incapable of evading it in order to translate it. Next, Donne relates death with other positions and conditions to frame it as their shared and unifying conclusion. He creates 
parallelisms by which love corresponds to death in the comparison within the disparities between "heat" (7) and "cold" (8), and youth and age (7):

Love with excesse of heat, more yong then old, Death kills with too much cold (7-8)

Donne argues in his Paradoxes and Problems that "by Discord things increase" (19-21). He explains:

while I maintaine it, and feele the contrary repugnances and adverse fightings of the Elements in my body, my body increaseth; and whilst I differ from common opinions, by this discord the number of my Paradoxes encreasesth. [...] And yf this unity and peace can give increase to things, how mightily is Discord and warr to this purpose, which are indeed the only ordinary parents of peace. $(19-20)$

In order to achieve this "unity and peace", he has to acknowledge and apprehend the "discord", in which the life in a love-desiring subject is compared to death. In fact, in this paradoxical state, his life is nothing more than a hallucination, a dream just as discussed of Sidney's Sonnet 32 in Astrophil and Stella regarding "deadly sleeping" and the "living-d[eath]" (Chapter One, p. 30). The living experience of this desire is so ambiguous that it is like the sunset lightdying yet still abiding — or the dwindling "heat" in an extinguished "fire":

Such life is like the light which bideth yet When the lifes light is set,

Or like the heat, which fire in solid matter

Leaves behinde, two houres after. (13-16)

In this conceptual ambivalence, the speaker recognises that the only possible way to voice his amorous desire is via death. This apprehension becomes so radical that the poet-lover himself transmutes into his own "Epitaph and Tombe" (18):

Once I lov'd and dyed; and am now become Mine Epitaph and Tombe.

Here dead men speake their last, and so do I;

Love-slaine, loe, here I dye. (17-20) 
Gauging from the last two lines, the obstacle to desire's satisfaction seems to have been overcome, and the speaker has fulfilled his aspiration for that "perfectest" love through the operation of the conceptual paradox in the life-death correlation. The poet-lover is "slaine", once again, just like Sidney's Astrophil in Sonnet 38 in Astrophil and Stella. However, this time, the "unkind" one who has "slaine" him is not his "Stella" but "love" itself, since he arbitrarily detaches his subjectivity from both his self and others. For Donne, by constructing detachment, the conformity and unification between the opposing extremes is eventually to be found in the most incongruous place. Inhering within this paradox is exactly the "Discord of extreames" which "begetts [...] vertues" (Paradoxes and Problems 21). Accordingly, the degenerate soul of the postlapsarian man can be cleansed, and "unity and peace", and the harmonisation through the purification of wit and the "enlarging of conceit", can be achieved (Defence 28).

However, this rhetorical action of detaching and disassociating is seldom friendly, but antagonistic. The unsympathetic yet aggressive aspect of amorous desire demonstrates in another way Donne's endeavour to search for a manner to convey accurately the Platonic ideal of love in a sensible term without the self-deception enacted in Astrophil's relinquishing of fleshly love. This endeavour is to be realised in his analogous representation of the male-female union in a simultaneously physical and spiritual fashion. In other words, in some of his poems, Donne typifies the sexual union of the male and female in a distinctly visible and tangible way, yet the conceptual correlations between images and conceits construct the parallelism as highly spiritualised correspondences, where the unification between the two aspects of the desiring subjects can be eventually established, though in a paradoxical mechanism.

Donne establishes this unity through a particular sacramental discourse. As Achsah Guibbory notes, the language he uses "is committed, exclusive, and as permanent as possible in a mutable, contingent world" ("Fear of 'loving more': Death and the Loss of Sacramental 
Love" 205). This demonstration can be found strikingly in his poem "The Flea". In this poem, the unification and harmony between the "extreames" of the infinite and the finite is comically displayed as an evanescent, sacramental prototype of the life to come, instead of an entirely fulfilled, perpetual materiality of the desiring man. The exceedingly physical and corporeal image of the flea in which the lovers" "two bloods mingled bee" (4) encompasses an intense significance in its correlation. Such a correlation is framed by analogy concurrently as the sexual act and holy matrimony in an implicit language of the sacramental union whereby the bodily and the spiritual becomes united and joined together. The reality of desire itself is presented to the reader via a discourse of symbolism in which the extreme disparities of male and female, subject and object are joined and bonded together in the "mingl[ing]" (4). In this "mingl[ing]", unification is achieved, and the obstacle to desire's satisfaction is broken. In this combination - the intercourse, the coition between the two opposing sexes - the "nothingness" which Donne explores in the poem "Negative love" recedes. The self-knowledge of the desiring subjects as knowing subjects and their love is available to be known, because in sexual intercourse, which results in "one blood made of two" (8), the lovers are ultimately able to "know" each other. ${ }^{35}$

The speaker continues his preposterous argument that since their bloods are mingled sexually, they are united matrimonially, by which unification the flea becomes their "mariage bed" and "mariage temple" (13). Here the conception of the lovers" "mariage" is intensely integrated with the physical and tangible essence of the flea. This rhetoric is very different from what Astrophil realises in his fanciful illusory where he savours the "Cherries" he has received-Stella's kisses - in his frantic desire. ${ }^{36}$ Comparatively, the abstracting process of

\footnotetext{
35 According to the note in John Donne's Poetry (Norton Critical Editions), in Aristotelean physiology, "intercourse was thought to involve a mingling of bloods (as was conception since semen was thought to be a form of blood)".

${ }^{36}$ See the Second Song and Sonnet 82 in Astrophil and Stella.
} 
Astrophil's perception of the object of his desire is far less substantial and less tangible than the consecrating process of Donne's flea. Instead of transferring the Platonic objectivity and the lustful experience merely into the personal site of the subject's internalised mind, Donne sets up the body of the flea as a microcosmic site wherein the lovers' passionate sexual desire is rigorously communicated in sacramental language.

In DiPasquale's words, in the flea, "a sexual Eucharist is celebrated" (173). According to the Calvinist theological interpretation, the Eucharist (a Sacrament) itself is an "external sign" by which the reality of salvation is sealed on the recipient. ${ }^{37}$ Now the conceit of the flea as a "Sacrament" becomes a sign and image that encapsulates simultaneously the abstraction and physical reality of the lovers' consummation. The poet boldly claims that the matrimonial and sexual union have already materialised since the sacramental correlation between the flea and the lovers has been suggested as such:

And in this flea our two bloods mingled bee;

Oh stay, three lives in one flea spare,

Where wee almost, yea more then maryed are.

This flea is you and $\mathrm{I}$, and this

Our mariage bed, and mariage temple is $(4,10-13)$

The flea's "consecration" becomes first the sacred vessel of the lovers' blood, and secondly, through the operation of the sacramental discourse, the rhetorical vessel for the poet to advance his argument for the lovers' consummation. By re-enacting and illustrating sexual love and amorous desire in sacramental language in which the meta-physical significance and the

\footnotetext{
${ }^{37}$ John Calvin explains the Sacrament as "an external sign, by which the Lord seals on our consciences his promises of good-will toward us, in order to sustain the weakness of our faith". Calvin also refers to Augustine's teaching regarding the Sacrament as "a visible sign of a sacred thing". Cited from The Institutes of the Christian Religion, 4.14.1. All citations from Calvin's The Institutes of the Christian Religion are from The Institutes of the Christian Religion, trans. Henry Beveridge. Christian Classics Ethereal Library, 2002.
} 
physical imagery are closely intermingled together, the conventional dualism of the Petrarchan love lyric is out-run.

\subsection{Conclusion}

The problems Sidney defined in Astrophil and Stella but did not conclusively solve are articulated by Donne, who continues the exploration of the possibility of communicating the ideal and the real, earthly and heavenly desire at the same instant. For Sidney's Astrophil, his logic is that it is impossible (or extremely difficult) to unify the struggle of physical passion and Neoplatonic principles. Moreover, it is the bold attempt of unifying them in expressing desire that causes problems. Donne's development of Petrarchism is displayed in his poetic exploration of the paradoxical nature of desire with a paradoxical means: his particularly distinctive usage of conceits, the "Discord of extreames". Struggling with the identical Petrarchan paradox inherent in tropes and metonymy that constitute desire and lovers yet extend the Petrarchan conceit, Donne's amorous poems can be recognised as bridging Petrarchism and anti-Petrarchism. In "The Canonization", by naming the woman a saint, he "pushes conventional tropes to an extreme in deploying the Petrarchan conceit" (Dubrow 223). However, by simultaneously suggesting that both lovers are postulants for canonization, he rejects "the humility and worshipful distance" between the desiring subject and the object of his desire which belong typically to the Petrarchan discursive conventions.

In Donne's Songs and Sonets, the speakers frequently desire to diminish (or at least substantially decrease) the distance between the conceptual and linguistic extremes. This is always done by means of deploying conceits in which disparate objects - such as earthly and heavenly desire, life and death, fleshly and spiritual love_-are being compared and correlated. Consequently, the speakers in these poems end up emphasising the distance between those extremes, and precipitating paradoxical language. In such paradoxical language, the 
oppositional and dualistic pattern of the traditional Petrarchan system - in which love for body and love for soul are always portrayed in mutually exclusive way-is ultimately surpassed. Like the lovers in "The Canonization" who "in [them] finde the'Eagle and the dove" (22), the desire that Donne celebrates in his amorous poems is performed in a paradoxical unity in which both the positive and the negative simultaneously exist, move, grow, and progress. Donne realises that in order to accurately epitomise the divine archetype, and reconcile that embodiment with the material, tangible context of the poet-lover, this process is inevitable. Moreover, it is in this continuous and constant process that Donne's speakers acknowledge the inherently conflicting and discordant nature of desire. 


\section{Spenser's Paradoxical Body and the Sidneys' Neoplatonic Psalmist}

Apart from the innovative framing of the conventional Petrarchan lover as discussed in Philip Sidney's Astrophil and Stella, and the creative implementing of conceits for the purpose of bridging conceptual gaps between "extreames" as found in John Donne's amorous poetry, another significant interest for the English Renaissance poets regarding their paradoxical expression of desire, is their execution of Neoplatonism, as I have begun to discuss in Chapter One. This chapter extends the concerns of Chapter One while exploring how the Renaissance Platonic understanding of divine and physical love evolved into a philosophical and religious complex, by which the poet-lovers voice their desires in a unique Neoplatonic discursive manner.

According to Plato, true beauty was only of the mind. In the Middle Ages through to the Renaissance, a philosophical school of thought called "Neoplatonism" was built and developed based on interpretations of Plato's works by Plotinus and others. Neoplatonism asserts that all beauty in the physical world is an emanatio (emanation) or radiation from the One and Absolute - the source of all being. Renaissance Neoplatonists regard the beauty of the body as the manifestation or exhibition of the moral and spiritual beauty of the mind (Abrams 223). For them, the ideal love is the love of the soul, yet simultaneously the human body is the physical representation of beauty. The appreciation of beauty in both the spiritual and the physical realms shows the paradoxical perception of desire as concurrently for body and soul, foreshadowing the later Elizabethan Puritan interpretation of the human body as a beautiful yet undoubtedly sinful and corrupted flesh.

This paradoxical perception of beauty is practically realised in the paradoxical articulation of desire. The Renaissance interpretation of Neoplatonism was that contemplation 
of earthly beauty enables the appreciation of abstract beauty. Objective beauty became idealised in woman. Following the Greek example and glorifying the human body in the nude, Renaissance artists derived an exalted morality from the unclad human figure. This is exemplified in Edmund Spenser's poetical works such as Amoretti and Epithalamion, in which the poet-lover perceives in the human body the perfection of grace and loveliness. However, this perspective becomes paradoxical when it is affected by the Elizabethan Puritan belief that the body should be "sacrificed to the needs of the soul, and that this might the more readily be accomplished men were bidden to loathe and revile it. [...] what a filthy, unclean, and ugglesome carcase do I bear about with me, that for very shame had need to be covered with garments" (qtd. in Sheavyn 175). In the Sidneys' Psalms, the foolishness and sinfulness of man is always ascribed to his desire of body and flesh. For example, Philip Sidney translates Psalm 14:1-2 as:

The foolish man by flesh and fancy led,

His guilty heart with this fond thought hath fed:

'There is no God that reigneth.' $(1-3)^{38}$

For Sidney, if man desires sinfully, it must be because he is drawn by the incitement of his "flesh and fancy". ${ }^{39}$ This inconsistency of perceiving love and expressing desire within the philosophy of Neoplatonism echoes the Petrarchan lover as portrayed in Sonnet 71 of Sidney’s Astrophil and Stella (see Chapter One, pp. 24-25). Similarly, the Sidneian Psalmist-as a Neoplatonic lover-consciously seeks to reconcile his spiritual love for the Divine to His

\footnotetext{
${ }^{38}$ However, in the Geneva Bible's translation, the intentional division of human as dichotomously a righteous soul combining with a guilty flesh — instead of existing as a unitary subsistence —is never made: "The fool hath said in his heart: There is no God". See 1599 Geneva Bible. Tolle Lege Press, 2006. All citations from the Geneva Bible are from this edition. According to Ringler, Philip Sidney consulted the Geneva Bible (505). Hence, I made textual comparisons between the two. All citations from the Sidneys' Psalms are from The Sidney Psalter: The Psalms of Sir Philip and Mary Sidney, ed. Hannibal Hamlin et al. Oxford University Press, 2009.

${ }^{39}$ A similar rendering and usage of discourse appears in Sidney's translation of Psalm 17:4. The Geneva Bible translates it as "Concerning the works of men, by the words of / thy lips I kept me from the paths of the cruel man". Sidney implements his presumption of the Platonic dichotomy concerning body and flesh: "Not weighing aught how fleshly fancies run, / Led by thy word, the rav'ners' steps I shun" (13-14).
} 
essential opposite - the physical and earthly substance - yet the two unavoidably contradict within him. As ardently Protestant poets, Spenser and the Sidneys resolve the problem in religion. Spenser's speaker eventually justifies his fleshly desire in Christian marriage, while the Sidneys' Psalmist David finds God in earthly and bodily realms through faith.

\subsection{Spenser's "chast desires" in Amoretti and Epithalamion}

Reed Way Dasenbrock observes in "The Petrarchan Context of Spenser's Amoretti” that the love condition Petrarchan poets narrate and the inclinations their poems express are represented by "instability" and "discontinuity" (38). The inconsistent and unstable character of Petrarchan desire is compounded by the Renaissance comprehension of Neoplatonism where spiritual love and its substantially antagonistic opposite, physical love, are constantly and consciously sought to be reconciled yet unavoidably contradict and conflict within the subject who yearns and desires. For Petrarch and Sidney (and perhaps Donne), since the paradox inherent within the love-desiring subject displays the emotions and perceptions of the poet-lover as continuously changing and shifting, the situation of loving desire will constantly be accompanied with selfabsorbedness, antagonism, and conversations within the poet-lover. Whereas Donne employs a certain sacramental language in his distinct conceits to establish paradoxical unities in order to harmonise the disparate "extreames", Spenser's speaker-experiencing this situation in Amoretti and Epithalamion - turns toward the "peace and rest" which is found "in the sacred world of marriage" (Dasenbrock 46).

Don M. Ricks distinguishes "love" in Elizabethan poetry from "courtship", explaining that the former is a "state" while the latter is a "process" (5). Spenser's Amoretti and Epithalamion could be categorised as representing a process in which the speaker sets forth his continuous endeavours to obtain the Christian Platonist ideals through desiring the sensuous and physical beauty exhibited in his lover's body. His Amoretti and Epithalamion display 
elegant and graceful descriptions of sensuous beauty interchanging with the elevated and sublime representations of spiritual transcendence.

In Spenser's representation of the ideal beauty through the process of his courtship, the bodily beauty of his lover repeatedly inspires and stimulates him paradoxically "burning in flames of pure and chast desyre" (line 12, Sonnet XXII), to the reflection of the spiritual beauty. In Sonnet XV, the speaker eulogises the beauty of his loved one excessively by asking the merchants why they are searching all over the earth for precious beautiful objects since all the world's treasures are exhibited and flaunted in the person of his lady:

For loe my love doth in her selfe containe all this worlds riches that may farre be found, if Saphyres, loe her eies be Saphyres plaine, if Rubies, loe hir lips be Rubies sound:

If Pearles, hir teeth be pearles both pure and round;

if Yvorie, her forhead yvory weene;

if Gold, her locks are finest gold on ground;

If silver, her faire hands are silver sheene. (5-12)

The hyperbolic blazon of the woman's physical charms (see also Sonnet LXIIII) seems rather conventional and typical, yet connecting with the following couplet one can see Spenser's Neoplatonic attempt to associate Platonic aesthetics - desire for ethical and spiritual goodwith the physical beauty displayed in bodily forms. The speaker's worship of the woman's body transcends the mere superficial appearance of the female physicality, and he is prompted to contemplate that:

\section{[...] which fairest is, but few behold, her mind adornd with vertues manifold. \\ (lines 13-14, Sonnet XV)}

This testimony of experiencing his lover's spiritual qualities — her "mind"-through her body carries the comprehension and desire of beauty not only beyond the physical, but also beyond the mutually exclusive expression in which bodily desire and spiritual desire are usually portrayed in Petrarchan lyrics. I do not fully agree with some scholars who read the Amoretti 
primarily in respect of the Neoplatonic ladder in which desire is pronounced as simply climbing from the physical towards the spiritual. ${ }^{40}$ Instead, I argue that Spenser's speaker adopts a distinct Neoplatonic perspective of understanding both aesthetics and ethics, and integrates it into his enunciation of desire that is ultimately constituted in Christian marriage. Spenser's poet-lover, as a Neoplatonist, seeing that all beauty in the sensible and physical world is an emanatio (emanation) or radiation from the One Absolute, the source of all being, regards the unfeigned beauty of the body as the manifestation or exhibition of the moral and spiritual beauty of the mind. Hence, rather than being perceived as completely immoral and corrupt, the yearning and passion for the female body is considered as "chast desires". This can be seen in line 8 of Sonnet VIII (also "chast desyre" in Sonnet XXII), since this desire aims toward a prospective marriage instead of any adulterous relationship. Though similar to Stella in Sidney's Astrophil and Stella, being seen as Heaven and the divine archetype itself, the object of Spenser's desire is regarded as Heaven on earth; she is that epitomised divinity expressed through mortal pattern, the spiritual ideal incarnated in fleshly form. The desire of Spenser's speaker does not climb the Platonic ladder up to Heaven where he finds both joy and harmony. Rather, they are obtained in the "sacred bond of marriage". As noted by Dasenbrock, there is no "rise" from physical to spiritual love: "the proper kind of physical love is spiritual" (48).

The ongoing exploration for that "proper kind of physical love" is exactly the "process" that Spenser constructs through this sonnet sequence. This search starts as early as in Sonnet VIII where Spenser describes the physical impacts and efficacies of rays from his lover's eyes, by which he expounds how those "chast desires" emerge and become definite under the influence of his beloved:

Thrugh your bright beams doth not the blinded guest,

\footnotetext{
${ }^{40}$ For example, see Edwin Casady in “The Neo-Platonic Ladder in Spenser's Amoretti”. Philological Quarterly, 20 (1941). pp.295.
} 
shoot out his darts to base affections wound:

but Angels come to lead fraile mindes to rest

in chast desires on heavenly beauty bound. (5-8)

The poet-lover praises with enthusiasm the guidance and enlightenment he receives through the woman's eyes. The "bright beams" (5) shining from his lover's eyes are not merely related to the passionate and personal character; more than that, they are considered to be the configuration of an exposition of spiritual values and ideals. At the same time, his lover's eyes are so real and physical as their effects are depicted as that of the "living fire" (1), her eyes are not to be equated to mere nature or the Sun, but are "Kindled above unto the maker neere" (2). The poet emphasises this idea again and stresses it more exhaustively in the next sonnet (Sonnet IX), where all the bright and beautiful objects including the Sun (5), the Moone (6), the Starres (7), the fire (8), the lightning (9), the Diamond (10), the Christall (11), and glasse (12) are considered not qualified to resemble his lover's eyes. He proclaims that his lover's eyesthough being a form as visible as everything else on earth-ought not to be compared with them according to the same aesthetic standard and objective level, but instead to be directly pointed to the invisible Creator, the Platonic Absolute from whom beauty and order of aesthetics derive:

Then to the Maker selfe they likest be, whose light doth lighten all that here we see.

(lines 13-14, Sonnet IX)

The desire for any of those lower physical objects listed from line 5 through to line 12 is not of "proper kind", because only the woman's body is "proper" enough to be the one physical form to represent the divine archetype. Back to Sonnet VIII, it is understandable that by desiring and pondering the physical and bodily object, Spenser's speaker begins to comprehend Platonic ideals, and to appreciate the higher morals and values. By the outer "physics", he is "frame[d]" (9), "t[aught]" (10), and "fashion[ed]" (9) within: 
You frame my thoughts and fashion me within, you stop my toung, and teach my hart to speake, you calme the storme that passion did begin, strong thrugh your cause, but by your vertue weak.

The paradox can be seen clearly in this sonnet, where the two comprehensibly contradictory desires — one for the physical and the other the spiritual — exist at the same instant and associate in harmony. Indeed, Spenser's desire belongs to a higher and elevated order, yet he adopts the basic and worldly articulations to express it. Moreover, these "chast desires" for his lady's beauty are not confined in the personal, but are declared in the universal:

Dark is the world, where your light shined never; well is he borne, that may behold you ever. (13-14)

Following these verses, Spenser's speaker further declares his lover's eyes to be the light that illuminates his spirit and mind in the beginning of Sonnet IX:

\section{Long-while I sought to what I might compare those powrefull eies, which lighten my dark spright}

The diverse and frequent Petrarchan conceits that Spenser implements in these sonnets ultimately serve his Platonism. Instead of simply gratifying his lust and fleshly desire, he directs conventional Petrarchism towards his "spright" (spirit). As Paul N. Siegel points out, the "veneration and awe" Spenser's speaker has for his lady are not "the mere rhetoric of the Petrarchists", but rather, the proclamation of "the genuinely idealistic sentiments of the Platonist who sees in the beauty of his mistress a manifestation of God" (177). Inevitably, a certain incongruity is engendered when the conventional Petrarchan categorisation of the woman's physical beauty is applied to pronounce the desire for her "mind adornd with vertues manifold" (line 14, Sonnet XV). However, this is exactly how Spenser operates his Neoplatonist logic. 
Throughout the sequence, Spenser coordinates the sensuous and physical beauty exhibited in his lady's bodily form towards the desiring of Christian Platonist ideals as the Neoplatonic absorption of beauty. In Siegel's words, the recurrent references to Neoplatonic postulation in Amoretti are not merely "intellectual excursions, unrelated to the wooing of the lady" (178). By expounding and illustrating the woman's body, Spenser's speaker is directed to grace and virtues. In Sonnet LXIIII, the poet-lover explores the sweet fragrances of the lady in every part of her body:

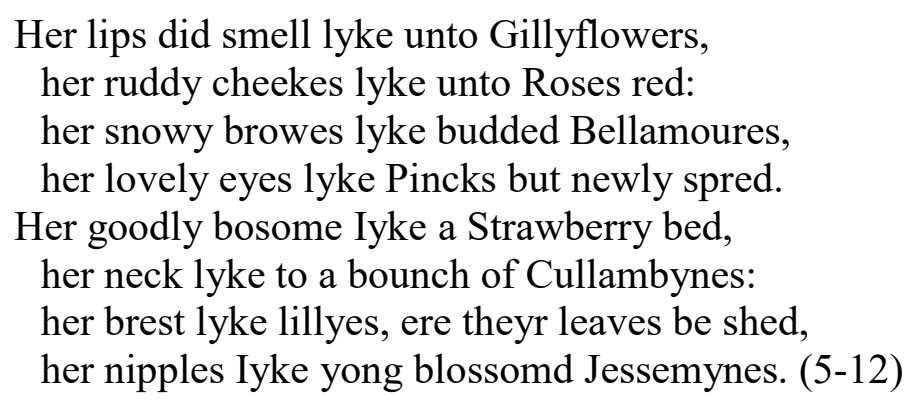

The bodily parts of his lady are compared to the earthly types of flowers and fruits. That those flowers and pleasant fresh fruits are grown and seen during spring coincides with the time Spenser wrote this particular sonnet. According to Kenneth J. Larsen, the eighty-nine sonnets in Amoretti were composed to parallel the liturgical structure prescribed by the Book of Common Prayer for specific dates in $1594 .^{41}$ The sonnets begin on January 23 and end on May 17, leading up to the poet's wedding to Elizabeth Boyle on June 11. With Sonnet LXVIII corresponding to Easter Sunday (31 March, 1594) and Sonnet XXII to Ash Wednesday, Sonnet LXIIII matches the season of early spring, a time of life and high spirit. By vividly depicting his lover's fleshly beauty in metaphors of natural and material objects such as blossoms and fruits, Spenser's speaker anomalously draws his anticipation of gratification and enjoyment not

\footnotetext{
${ }^{41}$ See Kenneth J. Larsen. Edmund Spenser's Amoretti and Epithalamion: A Critical Edition.
} 
simply on the possessing of the lady's body, but on the spiritual graces expressed and manifested in it. As the poet directly claims in the first lines of the sonnet:

\section{Comming to kisse her lyps, (such grace I found) \\ Me seemd I smelt a gardin of sweet flowres (1-2)}

The word "grace", meaning favour, is also an allusion to Christian religion. Yet it not only refers to the conventional Petrarchan comprehension of love that it is perceived as a religion able to reform and raise the poet, it is the seasonal gifts from the lady as the very representation of the Neoplatonic divine archetype from where spiritual beauty and ethical values derive. Being thoroughly in passionate love with his lady, he is advanced by her virtuous body to aspire to becoming a better human. Furthermore, this correlation in respect of Neoplatonic aesthetics is best expressed in marriage, especially marriage interpreted from a Calvinist perspective. Siegel points out that Spenser integrates Neoplatonic love with the "Calvinistic ideal of marriage" in Amoretti (165), and, in a Calvinist understanding, the sexual desire and sensual passion in a marital relationship is not sinful, but blessed and holy. ${ }^{42}$ By "kiss[ing] her lyps" and portraying her bodily beauties in analogy with the seasonal beauties of spring, the poet declares that having this lawful and rightful access to his lady's physical body ultimately brings him new life. After just coming out of the cold and demise of winter, the female flesh gives him warmth and makes him spiritually alive. During the process of seasonal change from winter to spring, and to summer, the temperature increases, which furthers the intensity of desire the poet-lover has for his lady. As the "Strawberry" (line 9, Sonnet LXIIII) is red, her warm and "goodly bosome" carries his continuously increasing love, "burning in flames of pure and chast desyre" (Sonnet XXII), in conformity to the elevated Platonic ethics with all their spiritual goodness.

\footnotetext{
${ }^{42}$ Cf. Jean Francesco A. L. Gomes. “The Meaning of Sex in John Calvin's Theology”.
} 
Throughout Amoretti, the audacious descriptions of the sensuous and physical beauty exhibited in human bodily form are always followed by articulation of desire for the Christian Platonist's ideals of the Neoplatonic absorption of beauty. These two widely conflicting perceptions of beauty constantly clash with each other yet bewilderingly coexist in harmony. Being comprehensibly contradictory to one another, they generate paradox, as the starting point, with harmony the state that is eventually reached. Sonnet LXXVI and Sonnet LXXVII can be regarded as the fleshliest instances in the whole sequence where the lady's bosom is worshipped, yet the poet-lover is ravished neither exclusively nor completely by the mere bodily beauty of his lover:

Fayre bosome fraught with vertues richest tresure, The neast of love, the lodging of delight, The bowre of blisse, the paradice of pleasure, The sacred harbour of that hevenly spright.

(lines 1-4, Sonnet LXXVI)

Spenser situates "vertues" within the female "bosome" (1). The location of that very fleshly and sexually arousing physical object is exactly where the Platonic ideals rest. All the Christian Platonic discourses he applies to the woman's "bosome"—_blisse", "the paradice", the "sacred harbour of that hevenly spright"-serve to foreshadow the spiritual ideals he is to desire ultimately later in Sonnet LXXIX. The poet-lover continues his exuberant praise of the lady's "bosome" in the next Sonnet (Sonnet LXXVII):

Was it a dreame, or did I see it playne, A goodly table of pure yvory:

Exceeding sweet, yet voyd of sinfull vice, That many sought yet none could ever taste, sweet fruit of pleasure brought from Paradice By Love himselfe and in his garden plaste.

Her brest that table was, so richly spredd, my thoughts the guests, which would thereon have fedd. 
As noted in William A. Oram's edition, the subject of these sonnets is not the poet, but significantly, his "thoughts" (line 13, Sonnet LXXVI; line 14, Sonnet LXXVII) which expeditiously lead to Sonnet LXXIX where direct contemplation of Platonic ideals is realised and enunciated:

Men call you fayre, and you doe credit it, For that your selfe ye dayly such doe see: but the trew fayre, that is the gentle wit, and vertuous mind, is much more praysd of me. (1-4)

Though seemingly incongruous and conflicting, it is exactly by the pondering of the fleshly beauty of the woman that the poet-lover transcends and comprehends the "trew fayre" (3) the essence derived from the Neoplatonic One Absolute- the "gentle wit", and "vertuous mind". Spenser's speaker proclaims his "thoughts" more explicitly in the following verses:

That is true beautie: that doth argue you to be divine and borne of heavenly seed: deriv'd from that fayre Spirit, from whom al true and perfect beauty did at first proceed. (9-12)

For Spenser, by examining Platonic beauty - the intellect, spiritual one - in visible form, especially in the woman's body, man can ultimately perceive that pure, spiritual beauty. In addition, if this desirous examination of the female flesh still awaits religious sanction in Amoretti since the lovers are not yet married, the consummation is to be fulfilled in Epithalamion where the paradoxical harmony is more explicitly expressed in the Christian marriage.

It is worth mentioning that in Petrarchan convention, seemingly conflicting and diverging realities rest not only in the simultaneous aspiration for conceptual extremities - the bodily desiring for the physical beauty and the spiritual craving for the Platonic "true beautie"- but also in the contrasting positions and locations of the poet-lover against his beloved. Consequently, many Petrarchan sonnet sequences have problematic endings because 
no satisfactory conclusion will be produced from the situations of desire they create. ${ }^{43}$ Since the poet-lovers typically desire a lady who is sexually unavailable, they repeatedly trap themselves into ceaseless self-absorption and egotism. Spenser solves this problem by celebrating his desire within Christian marriage where fleshly desire for his beloved is not only available, but also lawful and praiseworthy. ${ }^{44}$ The discord is to be dissolved by the "selfless and mutual concord", and the "egotistical self-display of Petrarchism" is suspended by the active observation of the spiritual and theological significances by means of the consecrated earthly union-in the world of marriage (Dasenbrock 46). Epithalamion appears harmonious yet still perplexing. In relishing his lady's bodily sensualities, her inner virtues are manifested as the essential and foremost qualities. Though being deliberately associated with divine patterns, she is still in an earthly substance just like the poet himself. Hence, as A. R. Cirillo points out, if the poet wants to "reach God", he is required to do so with the help of his lady "in the way that God intended, through marriage" (19).

Before concentrating on the spiritual qualities of his bride (185-203), Spenser first presents a conventional Petrarchan description of her physical presence (167-184):

So sweet, so lovely, and so mild as she,

Adornd with beautyes grace and vertues store, Her goodly eyes lyke Saphyres shining bright, Her forehead yvory white, Her cheekes lyke apples which the sun hath rudded, Her lips lyke cherryes charming men to byte, Her brest like to a bowle of creame uncrudded, Her paps lyke lyllies budded, Her snowie necke lyke to a marble towre, And all her body like a pallace fayre, Ascending uppe with many a stately stayre, To honors seat and chastities sweet bowre. (169-180)

\footnotetext{
${ }^{43}$ For example, Petrarch may have resolved the problem in his rejecting of physical love and in the death of his beloved Laura.

${ }^{44}$ In Carol V. Kaske's words, "only in an epithalamion can the sensuous and the spiritual coexist, for then whatever comes naturally is right". Cited from "Spenser's 'Amoretti and Epithalamion' of 1595: Structure, Genre, and Numerology".
} 
The contraries of the flesh and spirit should be first presented and then reconciled. Echoing what he does in Sonnet LXXVI and Sonnet LXXVII of Amoretti, Spenser unveils the bodily beauty of the woman, presenting his model of beauty and goodness. Then in the next stanza, the poet directs his thought from the emphasis on his lady's outward beauty to the focus of "The inward beauty of her lively spright" (186) — her inner virtues. The set of verses listing his bride's inner beauty is not completely unlike the typical blazon in the previous stanza where the various parts of the female body are singled out for metaphorical praise, because the inner virtues listed in this stanza can be interpreted as another kind of "blazon" in spiritual and metaphysical terms. This stanza is a catalogue of spiritual beauty in correspondence with the fleshly beauty recited before, of physical and visible attractiveness in harmonious correlation to the meta-physical "chastities" (180) and Platonic ideals that "no eyes can see" (185):

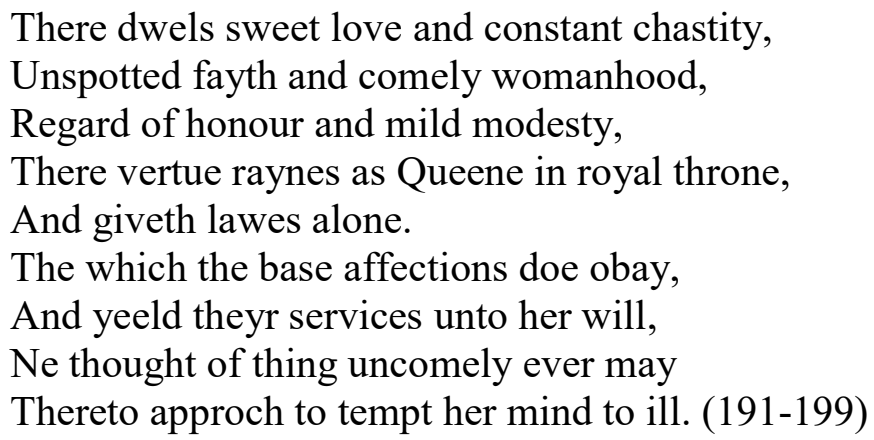

It is undeniably paradoxical that the spiritual virtues recognised and comprehended through the passionate examination of the female flesh actually restrain the "base affections" (196), which are usually the inevitable result of such amorous observations. However, according to Spenser's Neoplatonism, internal and external beauty do not necessarily exist in such positions that they are mutually exclusive. The fleshly beauty of his bride is in unity and concord with her essential nature - the "constant chastity" (191) - hence his desire for her is never "base" but "pure and chast" (line 12, Sonnet XXII). The Neoplatonic conviction that beauty and truth are homogeneous and identical is expressed in Spenser's other poetical works, especially in 
The Faerie Queene. For example, bodily charm and spiritual truth are inseparably united in Una whose

\section{$[\ldots]$ angels face}

As the great eye of heaven shyned bright,

And made a sunshine in the shadie place;

Did never mortall eye behold such heavenly grace.

(Book I, Canto iii, 4$)^{45}$

The beauty of truth is so powerful that the "ramping Lyon" (Canto iii, 5) is to be subdued, and the wild woodgods "stand astonied at her beautie bright" (Canto vi, 9). As Una is heavenly beauty exhibited and symbolised in woman, so Spenser's bride is "Garnisht with heavenly guifts of high degree" (line 187, Epithalamion).

Stanzas 12 and 13 (204-241) of Epithalamion depict the "sacred cermonies" (216) of the wedding, marking the climax of the day. Beginning with an allusion to the Book of Isaiah, the beloved bride of the poet is implicitly compared to the "righteous nation, which keepeth the truth":

Open the temple gates unto my love,

Open them wide that she may enter in,

For to recyve this Saynt with honour dew,

That commeth in to you. $(204-205,208-209)^{46}$

The temple is about to receive her, the "Saynt". As Cirillo brilliantly notices, if his beloved lady is the conventional "saint of the religion of love", she is now a saint "taken seriously", because she is "before th'almighties vew" (211) at the "high altar" (215). Unlike the lovers in Donne's "The Canonization" who achieve sainthood in their own terms, Spenser's bride is a

\footnotetext{
${ }^{45}$ All citations from The Faerie Queene are from Edmund Spenser's Poetry (Norton Critical Editions). W. W. Norton \& Company, 1982.

46 "Open ye the gates that the righteous nation, which keepeth the truth, may enter in" (Isaiah 26:2). Possibly also a reference to the Psalms, "Lift up your heads ye gates, and be ye lifted up ye everlasting doors, and the King of glory shall come in." (Psalm 24:7, 9). Cited from 1599 Geneva Bible.
} 
saint herself, realised in the sacred matrimonial union of Christian love celebrated in the Neoplatonic framework. In this Protestant marriage, the physical love of the poet is paradoxically coordinated with the "proper" one, that is the spiritual one, the divine and heavenly one. The exploration of this "proper kind of physical love" is now satisfactorily resolved in this ceremonial confirmation, where

\section{[...] the roring Organs loudly play}

The praises of the Lord in lively notes (218-219)

The two constantly and intensely conflicting desires of beauty - the spiritual and the fleshlyharmoniously coexist in this virtuous union. This epithalamion, as a psalter of love, continues in the "joyous Antheme" of the "Choristers" (221) and the "Alleluya" of the "sweet Angels" $(240)$.

\subsection{The Sidneys' Neoplatonic Psalmist, a "right poet"}

James S. Lambert notes that Spenser's Epithalamion demonstrates certain "communal joy" in its public celebration of Protestant marriage in the manner of "psalmic refrains". A kind of "blessedness or even grace" is presented in the poem, resembling sacramental worship and especially the practice of "reciting the Psalms", combining "the discourses of joy-psalmic praises, hymnody, spiritual comfort, heavenly foretaste, festivity, matrimony, and finally, sex-into an all-inclusive articulation" (80). The reason the Psalms are applied by Elizabethan Protestant poets like Spenser as effective resources to bridge the gaps between contradictions and extremities — in Spenser's case, fleshly and spiritual desire — is that they are paradoxically divine and human at the same time.

This is particularly true for the translations of the Psalms started by Philip Sidney and completed after his death by his sister Mary, Countess of Pembroke. Interestingly, verbal and formal parallels suggest that Philip Sidney undertook his translating project of the first forty- 
three Psalms during the same months or years when he was writing his amorous sonnets Astrophil and Stella.$^{47}$ Hence, it is improper to say that Sidney had a "secular" literary career followed by a "sacred" one; in fact, as Perry and Stillman confirm, "the humane and the sacred intermingle at every point - among the works and within them" (330). Though it was firmly believed by the Protestant Reformers that, as part of the Scriptures, the Psalms are divinely revealed, thus are God speaking, the human emotions and experiences discursively conveyed in them were never neglected by the Reformers. John Calvin finds in the Psalms:

all the griefs, sorrows, fears, doubts, hopes, cares, perplexities, in short, all the distracting emotions with which the minds of men are wont to be agitated. $^{48}$

Sidney acknowledges that within the Psalms, the divine and the human interconnect with one another, unavoidably creating paradox. He responds to the tension by integrating his Neoplatonic thoughts into his innovative rendering of the Psalmist-in the framing of his divine voice and human voice. As a Neoplatonic lover, Sidney's Psalmist yearns for the Divine presence and communion by constantly searching in the earthly realm and expressing God through physical terms. The object of the Psalmist's desire is God himself who-as the beloved of the poet-lover-demands that the Psalmist should transcend beyond his own condition by faith, in order to see, to imitate, and to praise God. However, this aspiration of the Psalmist becomes paradoxical when the poet-lover recognises that he constantly fails because of his own physical reality-his limitation as a fleshly human being who lacks knowledge and is ontologically distant from his Creator. Hence, the desire to convey his Neoplatonic love for the One and Absolute through earthly expression results in paradox when the earthly domain constrains him for reaching to the heavenly realm.

\footnotetext{
${ }^{47}$ See L. M. Klein. The Exemplary Sidney and the Elizabethan Sonneteer. University of Delaware Press, 1998.

${ }^{48}$ In Calvin, "The Author's Preface" to Commentary on Psalms, trans. Rev. James Anderson in 1845. Christian Classics Ethereal Library, 2005.
} 
Sidney states in A Defence of Poetry that David the Psalmist makes the readers "see God coming in His majesty" (22). As an earthly human being, the Psalmist tells of

the beasts' joyfulness and hills leaping, but a heavenly poesy, wherein almost he showeth himself a passionate lover of that unspeakable and everlasting beauty to be seen by the eyes of the mind, only cleared by faith [...] (22)

The Neoplatonic desire to speak of the "unspeakable", transcendent, divine beauty through earthly "eyes" and "mind" generates paradox. For Sidney, the Psalmist as a Neoplatonist is a mediator and a translator of the spiritual ideal into the physical real. Katherine Duncan-Jones notes that Sidney's poet is "a man who religiously cultivates this ability [the mediating function] to the utmost of his powers". The Psalmist's “ideas", in Duncan-Jones' words:

being ideas of "first nature", with the force of a divine breath show "another nature" to an imperfect world that lives in second nature. In this way poesy is the effort of an individual mind to bridge the [ontological] gap between the sinful state and the lost paradise or "golden" age of the human being. (78$79)^{49}$

Sidney's paraphrase of Psalm 23 shows this typical Neoplatonic attempt to bridge the ontological gap and present the "lost paradise". Compared to the Geneva Bible in which the Psalmist says, "I shall not want" after declaring that God is his "shepherd", Sidney's Psalmist says something different: "And so can never I / Taste misery" (2-3). From the very first sentence of this Psalm, the poet-lover David exemplifies his desire to translate the divine into the physically real. What the word "taste" denotes regarding its sensuous and physical experience is indicated throughout Psalm 23. As the One Good Shepherd, God will never let his beloved "taste" misery. By the Divine guidance, the poet-lover will instead "taste" the spiritual goodness embodied in the earthly beauties that emanate from the heavenly Beauty:

He rests me in green pastures his:

\footnotetext{
${ }^{49}$ Cf. Notes given in J.A. Van Dorsten's edition of A Defence of Poetry concerning Adam's will and his wit. pp. 82-83. I have briefly discussed it in Chapter One, p. 32.
} 
By waters still and sweet

He guides my feet. (4-6)

The yearning of Sidney's Psalmist for the Divine presence and love is epitomised in this very image of the "green pastures". First, as pastures are in themselves delightful to behold, this physical image of pastoralism directly suggests earthly beauty, which precisely signifies the spiritual beauty of the One and Absolute. Secondly, this material imagery of the "green pastures" suggests nourishment. As the humble sheep desires for the love of the "shepherd", the shepherd supplies food to the poet-lover for his soul, echoing the word "taste" (3).

This kind of discourse that designates the Neoplatonic comprehension of reaching to the meta-physical One through experiencing the physical medium appears in many other places throughout the Psalms. For example, in Psalm 34, Sidney uses the adjective "sweet" to relate to how David the Psalmist "taste[s]" and "see[s]" the grace of God who promises to save him:

I say but taste and see,

How sweet, how gracious is His grace:

Lord, he is in thrice blessed case

Whose trust is all on thee. (29-32)

This shows the essentially paradoxical nature of the Psalmist's desire. He indulges his physical desire in his expression of the desire for the spiritual love. In other words, David the Psalmist operates his Platonic desire for God in his application of the physical and earthly discourse.

The visual appreciation of the beautiful scene of the "green pastures" in Psalm 23 parallels the poet-lover's spiritual perception of the meta-physical Truth that is God himself. Sidney states specifically in the Defence, "that unspeakable and everlasting beauty" can only "be seen by the eyes of the mind" (22). Resting in God's "green pastures", the poet-lover is nourished when the eyes of his mind are opened to receive Divine love and inspiration. As the mere act of "tast[ing]" natural food is enjoyable, so the spiritual nourishment is lovely and satisfying. This expression of eating is more clearly exhibited in the last stanza of Psalm 23, where the Psalmist says: 
Thou oil'st my head, thou fill'st my cup:

Nay, more, thou endless good,

Shalt give me food. (19-21)

Compared to the Geneva Bible, the content in Sidney's lines 20-21 seems to correspond to the first half of verse 6 where it reads, "Doubtless kindness and mercy shall follow me all the days of my life". For Sidney's Psalmist, the "kindness and mercy" from God which "follow me all the days of my life" are all encapsulated in the evidently Platonic phrase "endless good", which rightly correlates with "food" in line 21 , and the love and spiritual goods from God are as pleasant as a real banquet, an actual feast. Having experienced the Divine love displayed in the physical and earthly realm of "pastures" and "food", David as a Neoplatonic poet-lover unsurprisingly manifests his desire to "ascend up" to the heavenly places at last:

To thee, I say, ascended up,

Where thou, the Lord of all,

Dost hold thy hall. (22-24)

Again, this rendering is extremely different from the Geneva Bible, and the notion of "ascending up" is completely added into the translation by Sidney. ${ }^{50}$ Nevertheless, this is the exact fashion in which Sidney portrays the Psalmist as a Neoplatonic lover whose desire is to reach and transcend to the divine by translating and mediating through earthly objects.

However, the optimistic contemplation of the physically real is not always delightful from the perspective of Protestant poetics, since as part of creation, human beings are sinful and radically depraved. Hence, the Neoplatonic desire for Divine love becomes problematic. Resorting exclusively to the earthly and the fleshly in order to represent and imitate divine beauty encounters paradox. I further argue that the desire for the divine that Sidney's Psalmist demonstrates is expressed and experienced in two different ways, paradoxically operating at

\footnotetext{
${ }^{50}$ The Geneva Bible simply reads, "I shall remain a long season in the house of the Lord".
} 
the same instant. The human David as a Neoplatonic lover - a "passionate lover" of that "everlasting beauty to be seen by the eyes of the mind" (Defence 22) - recognising the ontological and substantial difference between him and God, and the depravity within himself, expresses the desire to constantly yearn to cling to God by praising and imitating the "excellencies" of Him. The same desire subsists in the voice of the Psalmist as in the typological Christ, and searches inwardly for inspiration and transformation, as subsisting in the "right poet" that Sidney postulates in his Defence.

As asserted in the Defence, the "right poet" is presented as inherently possessing certain human excellence in which knowledge within him has the ability to ascend to imitate perfectly the divine archetype:

For these third be they which most properly do imitate to teach and delight, and to imitate borrow nothing of what is, hath been, or shall be; but range, only reined with learned discretion, into the divine consideration of what may be and should be. (26)

Instead of devising the Psalmist as retaining a fundamental unity in his expression of desire, Sidney consciously divides the unified human disposition into contrasting compulsions. For him, the poetical condition of David the Psalmist constructs the crucial interconnection between God and human-for within the Psalms, it is comprehended that the articulations of different desires are concurrently existent. Anne Lake Prescott describes David in "King David as a 'Right Poet': Sidney and the Psalmist" as one whose "infolded voices" articulate David's own condition, Christ, and ourselves (134). In this way, David is not only that type of poetlike those divine poets - who praises God in his Platonic imitation of the "unconceivable excellencies of God" (Defence 25), but also the exact "right poet" himself who builds the ontological bridge between God and man. He does so in his innovative representation of reality by applying his "learned discretion" (26) to express the difficulty of moral and spiritual perfection. 
G. F. Waller notes that Calvinists seemed to have a problem dealing with Psalm 8, where the speaker pronounces a certain degree of the "glorification" of man. ${ }^{51}$ The Geneva Bible reads:

\author{
What is man, that thou art mindful of him? and \\ the son of man, that thou visitest him? \\ For thou hast made him a little lower than God, \\ and crowned him with glory and worship. (verses 4-5)
}

Waller points out that the Geneva Bible appears uneasy in declaring that God had no need to come "so low as to man, which is but dust". He mentions Calvin's disapproval of the Psalm's "rhetorical extravagance" and his stressing awkwardly the doctrine of the depravity of man by emphasising him as a creature who is "miserable and vile". ${ }^{52}$ These verses seemed to be used to acclaim the inherent excellence of human dignity, and to argue for man's competence to become a divine being. However, this is exactly what is not shown in Sidney's translation.

Sidney's Psalmist in this particular Psalm is by no means divine himself, but is rather that kind of Neoplatonic lover who, acknowledging the ontological gap between himself and the divine substance, desires to glorify the one outside of him instead of anything within himself:

\author{
Then think I: 'Ah, what is this man \\ Whom that great God remember can? \\ And what the race of him descended, \\ It should be aught of God attended?
}

\footnotetext{
${ }^{51}$ Waller's thesis “This matching of contraries': Calvinism and courtly philosophy in the Sidney Psalms" elucidates the historical rivalry between the orthodox Protestantism as represented by Elizabethan Calvinism, and the Brunian philosophy stressing man's divinity. Giordano Bruno, who perceived Calvinism as extremely repugnant, had a great appreciation of Sidney. Bruno saw Sidney as his intellectual ally whose poetical works demonstrated — as he understood — bold philosophical and theological assertions that man is ontologically kindred to the Divine, and that the desire of returning to the Neoplatonic One and Absolute can be achieved by his volitional imitating and representing the Divine mind. Bruno's celebration of man's divinity is unlike the notion in Neoplatonism where the poet endeavours to resemble the Divine by eluding from the physical realm; instead, it is the idea that man searches within himself inwardly for the embodiment of Divinity. Sidney does let his Astrophil reverse the Neoplatonic ladder of love and seek within himself for the reflection of his ideal Stella. However, I doubt to what extent Sidney's Psalmist resembles the Brunian view of man's divinity if his translation of the Psalms is to be referred to for the argument.

${ }^{52}$ See The Psalms of David and Others, with M. Calvins Commentaries, trans. Arthur Golding. London, 1571.
} 
Compared to the Calvinist version, the attributive word "great" is added before "God" by the translator to further display the huge disparity between the two subjects. The two rhyming verbs "descended" (15) and "attended" (16) denote two vastly contrasting directions that point to thoroughly different entities - the human and the Divine. Human beings as a whole are a "race" that descended, degenerated, and fell, to whom only God—with the meanings of taking care of and looking after-attends.

Then the Psalmist continues his thought: "For though in less than angel's state / Thou planted hast this earthly mate" (17-18). By using the word "earthly", Sidney emphasises the Platonic dichotomy between the earthly and the heavenly, the material and the spiritual. Humans are not inherently good and virtuous but are nothing more than those materials that belong to the earth. This discourse of examining the universe in dichotomous supposition, seeing earth as contrary to heaven, is applied in Sidney's other Psalms. For example, Sidney translates the second half of the first verse in Psalm 14 as:

\section{$[\ldots]$ he, and all his mates}

Do works, which earth corrupt, and heaven hates:

Not one that good remaineth. (4-6)

However, "attended" by God through planting in the state "less than angel" (line 17, Psalm 8), humans are capable, not to become God, but to imitate the divine attributes and essence. In this sense, Sidney's Psalmist mirrors the Neoplatonic lover who not only desires to praise the One and Absolute from whom all beauty in the earthly realm emanates, as discussed of Psalm 23, but also desires to imitate that essence and source of all excellencies. In addition, humans are able to act on this imitation and desire to imitate the Deity because they themselves are made in the Imago Dei. Hence, though they are depraved and descended, glory and honour remains in them as image-owners: 
Yet hast thou made ev'n him an owner

Of glorious crown, and crowning honour.

(lines 19-20, Psalm 8)

Knowing the state of himself and his ontological relation with the Divine being, the Psalmist as a Neoplatonic poet-lover can thus desire to ascend above the limitations and restrictions of his earthly condition, and - as Sidney declares in the Defence - "to lift up the mind from the dungeon of the body to the enjoying his own divine essence" (28). Philosophers who follow Giordano Bruno might conveniently take these phrasings out of context to propound their celebration of man's divinity. Waller notes that Bruno understands humans as possessing the ability to ascend by the power of their own minds to "encompass all creationanimals, [...] and even God Himself” (332). For Bruno, humans have not only the desire but also the capacity to fulfil such an aspiration. Yet, this is significantly different from how Sidney depicts the desire of the Psalmist in his rendering of Psalm 8. Sidney might not be against the Renaissance humanist view of man being a microcosm, but he would not agree with the interpretation of the Brunian philosophers, according to whom humans are seen as partakers of both the human and the divine essences.

Indeed, humans - bearing the Divine image — in responding to God's sovereignty, are lawfully sovereigns themselves over the animals on earth. Yet for Sidney, they are explicitly "ordainèd" by the Divine to "reign":

Thou placest him upon all lands

To rule the works of thine own hands:

And so thou hast all things ordainèd,

That ev'n his feet have on them reignèd.

(lines 21-24, Psalm 8)

Obviously, Sidney does not see humans as inherently divinely sovereigns; instead, they only reign in response and correlation to God's divine ordination. In the following two stanzas, Sidney expresses his comprehension of how the Neoplatonic Psalmist "encompass[es] all creation, [particularly] animals", but definitely not "God Himself". The Psalmist declares that 
under humans" dominion, God placed "sheep and oxen" (26), "all the beasts" (27), "bird[s] [...] of the air" (29), and "fish [...] of sea" (30). Finally, the Psalmist concludes in the last two lines: "O Lord, that rul'st our mortal line, / How through the world thy name doth shine!'” (33-34). The ontological and substantial difference between man and God is recognised and confirmed by the Psalmist as a Neoplatonist. Indeed, the poet-lover yearns for his divine origin, desires to conform himself into that ideal image-bearer that God has "ordainèd", who owns the "glorious crown, and crowning honour" (20). Yet, knowing that he belongs to the "mortal line" (33), he turns to praise God's name. The last word in the Psalm, "shine” (34), denotes Sidney's Neoplatonist idea of emanatio (emanation) and "radiation", that the sole source of physical and earthly beauty is reaffirmed as coming from the One and Absolute whose name alone shines.

However, the Psalmist is not merely a divine poet — according to the definition given in Defence — who desires to imitate and praise the "excellencies" of the Absolute in accordance with the Neoplatonic doctrines. As a "right poet" who possesses "learned discretion" himself and searches inwardly for inspiration, the Psalmist demonstrates his desire in an alternative way. He does this in another "voice" that is able to articulate not his own condition as a mere human being, but that of Christ as the perfect human being and the mediator between the Divine and human. In this innovative representation of truth, the Psalmist expresses what he contemplates as spiritual perfection.

Sidney would not be unfamiliar with how other Scriptures refer to Psalm 8 . The author of the Epistle to the Hebrews quotes Psalm 8:4-6 in Chapter Two Verses 5-9 when speaking of Christ to whom "the world to come" has been "put in subjection". ${ }^{53}$ Verse 9 explicitly confirms the theological typology that recognises this "owner / Of [the] glorious crown" as a type prefiguring Christ, saying, "we see Jesus crowned with glory and honor, which was made little

\footnotetext{
${ }^{53}$ Hebrews 2:5. 1599 Geneva Bible.
} 
inferior to the Angels". ${ }^{54}$ The commentators of the Geneva Bible elucidate that what is written in Psalm 8:4-6 "is already fulfilled" in Christ who was "for a time for our sakes inferior to the Angels, being made man: but now is advanced into most high glory". It is understandable that the desire pronounced in Psalm 8 is at the same instant from a divine mind and a human mind. In Sidney's rendering of Psalm 8, by emphasising the ontological differences between God and man, the Neoplatonic dichotomy of the earthly and heavenly, and of the Divine and human is resolved. The distance between the contraries is bridged by the voice of the Psalmist as the typological Christ who is the unique God-man.

Michael Raiger explains Protestant poetics in "Sidney's Defense of Plato" as established on a "strict dichotomy" between contrary objects, which stems from the presupposition of an "unbridgeable epistemological gap between creature and Creator" (32). For Sidney, the Psalmist's primary desire is to praise God, and to perform that in his pursuit of knowledge — knowledge of himself and knowledge of God—through constantly searching for inspiration and imitation. This knowledge is concurrently human and divine, coming from the Divine mind and precipitating in the human mind. In Psalm 2, Sidney explicitly uses such language to point out that the "heath'nish rage" (1) of those "earthly" (3) sovereigns who are against God derives straightforwardly from their lack of "knowledge" in their "mind": “Therefore, O kings, be wise, O rulers, rule your mind, / That knowledge you may find" (2324).

Sidney identifies in the Defence that in order to achieve the end of poetry, learningas the "purifying of wit" - is a necessary aid, and its purpose is "to know, and by knowledge to lift up the mind from the dungeon of the body to the enjoying his own divine essence" (28). However, the ontological and epistemological gap between human and God is effected by sin,

\footnotetext{
${ }^{54}$ See 1599 Geneva Bible.
} 
and thus results in the loss of this knowledge, and the inherent ability to learn. As Raiger phrases it, "direct knowledge of God is completely obliterated with the interposition of sin" (33). The most intense paradox of desire is occasioned at this very moment when the "right poet" is driven to search within himself for the innovative representation of the divine. Yet, because of the debilitating effects of sin, the potency of the reflection in satisfactorily representing God is thoroughly called into question. Sidney's Psalmist David responds to the problem by engaging with a negative process of imitative representation, that is to say, that speaking as a Neoplatonic poet-lover and also a "right poet", he simultaneously searches in himself and away from himself for a kind of love that incorporates both the earthly and the heavenly.

Consequently, the Psalmist operates his desire in two layers that affect one another expressively. In the first layer, his desire operates in a similar way to Spenser's speaker in Amoretti and Epithalamion, in which the poet-lover works his desire through the mechanism of the Neoplatonic emanatio (emanation), pursuing the divine beloved through the appreciation of the physical. He persistently desires spiritual goodness in the earthly sphere, endeavours to imitate God and to reach Him, while at the same time, his desire is processed in the second layer. Because of his postlapsarian state, due to which he is unable to produce any authentic imitations of God by himself, he paradoxically subsists the same one desire in his voice as Christ — the "second Adam"- - who pronounces the "lost paradise" of the first Adam — the "golden" age of humans - by searching inwardly for poetic representation of the Divine. The poet, being simultaneously a creation (of God) and the creator (of poetry) himself, "speaks of the perfection lost by Adam's transgression" (34), in Raiger's notes. This strongly echoes the consequence of the Neoplatonic emanatio, namely, remeatio, which means returning and 
reunion. ${ }^{55}$ Hence, the Psalmist is able to operate his desire to praise God and rejoice in the divine, with not only his "mind" but also his body, and even his "bones" as if they were not yet blemished in the paradise as before the fall:

Then shall I joy in thee, then saved by thee, I both in mind and bones shall gladded be.

(lines 19-20, Psalm 35)

Raiger discusses the place for the "right poets" in the Reformed church, which is instituted as a revelation of "the human ordained at creation to aspire to goodness". In this way, the "right poet" acknowledges that he is not able to represent God as $\mathrm{He}$ is, but "humans as they ought to be $[\ldots]$ according to God's command" (34). Now it is clearer that the "owner / Of glorious crown, and crowning honour" in Psalm 8 (19-20) is the human that God has ordained in the "paradise" by whom Christ speaks through the Psalmist David; he is also the one whom the Psalmist eagerly desires to become. The epistemological gap is to be eventually filled by the intermediate voice of Christ, the one who truly "reignèd" as can be found in Psalm 22:

And reason, since the crown to God pertaineth, And that by right upon all realms he reigneth. They that be made ev'n fat, with earth's fat good Shall feed, and laud the giver of their food. (69-72)

By the intermediate discursive power of Christ, David the Psalmist can finally satisfy his desire by transcending his own physical reality — his limitation of lacking in knowledge and being ontologically distant from the Divine. However, in order to feed on that "food", the Psalmist lacks one more thing. Sidney asserts in the Defence that David makes the readers "see God coming in His majesty" which is "to be seen by the eyes of the mind", but "only cleared by faith" (22). In taking Sidney's Defence as an argument for Protestant poetics, Andrew D.

\footnotetext{
${ }^{55}$ On emanatio and remeatio as a sequence in the experience of love, see Marsilio Ficino and Pico della Mirandola.
} 
Weiner considers Sidney's description of the Psalms as an example of what the Christian poet may accomplish with eyes "cleared by faith". ${ }^{56}$ The paradox of the Psalmist's desire to imitate and praise God can only be resolved through faith, through trusting the "heav'nly power", as we find in Psalm 37:

Do well, and trust on heav'nly power, Thou shalt have both good food and place. (7-8)

This is how the paradoxical desire of David the Psalmist operates. He expresses his desire for Divine love through contemplating earthly beauty and the physically real in a Neoplatonic frame, yet once obstructed, he articulates his voice through the typological Christ who provides "food" to be received only by "faith". In this manner, the Neoplatonic loving relationship is finally established by the Psalmist's trusting in the Divine mercy, "drinking" from the Divine "spring”. The satisfaction of his desire is so physically real that it extends even beyond the understanding of his mind:
O Lord, how excellent a thing Thy mercy is, which makes mankind Trust in the shadow of thy wing, Who shall in thy house fatness find, And drink from out thy pleasures' spring Of pleasures past the reach of mind.

(lines 19-24, Psalm 36)

In this way, the Neoplatonic One and Absolute is ultimately apprehended. And this is the only way that human beings can comprehend beauty and love in the sensible and physical world, which are mere emanations and radiations from God - the essence and source of life. Followed by a rhetorical question "For why?" Sidney answers through the human poet-lover David who creates the Psalms as a love poetry for the Divine:

\section{[...] The well of life thou art}

\footnotetext{
${ }^{56}$ See “Moving and Teaching: Sidney’s Defence of Poesie as a Protestant Poetic”. 2 (1972): 259-78.
} 
And in thy light, we shall see light.

(lines 25-26, Psalm 36)

\subsection{Conclusion}

Dasenbrock's claim of Spenser's Amoretti that "the proper kind of physical love is spiritual" (48) is in some way in accordance with the immanent notion in the Sidneys' Psalms. Both Spenser and Sidney indicate the Renaissance paradoxical understanding of desire as a uniting principle of the body and the mind, drawing from Renaissance Neoplatonism. While Spenser's speaker in Amoretti and Epithalamion seeks and successfully reconciles his sensual desire with the Platonic conceptions of love through the religious union of Protestant marriage celebrated in the Neoplatonic framework, Sidney's Psalmist searches within the earthly and physical realms - within nature and his own body — to express his desire to imitate God and praise the Divine being.

In the sixteenth century, the Psalms were perceived as an anatomy of the soul. Calvin illustrates in the introduction to his commentaries on the Psalms that "a man shalnot find any affection in himselfe, whereof the Image appeareth not in this glasse". ${ }^{57}$ Calvin's statement concerning the "Image" and "glasse" is crucial to the Neoplatonic doctrines that are distinctly embodied in Spenser's and Sidney's works. As Neoplatonic lovers, both Spenser's speaker and Sidney's Psalmist see the "Images" of bodies shining in their minds as if in a "glasse" (or mirror). The "Image" is the representation and reflection of the idea, and their desires correspond to the form of the idea with the form of the imprint of the sensible body. The two poet-lovers perceive the body as an object of delight, the beauty of holiness, of truth, of chastity that was to be desired, yet both of them recognise that there is the repulsiveness of corruption in the flesh that was to be despised. Hence, attempting to comprehend inherently and inevitably

\footnotetext{
${ }^{57}$ Cited from Jean Calvin, Commentaries on the Psalms, trans. Arthur Golding. London, 1571.
} 
paradoxical desire, they resolve the problem in Christian marriage and faith respectively. Unlike Astrophil who is an unfavourable example, Spenser's lover and Sidney's Neoplatonic Psalmist do not let their passionate desires determine their narratives of desire and poetic creation. Instead, they pursue an imitative representation of true love, a love where the poetlover ultimately gives up Petrarchan self-absorbedness and antagonism. In order to satisfy his desire, a poet-lover has to reach that "selfless and mutual concord" (Dasenbrock 46) first. Then, he is able to recognise that the physical and earthly realm including himself is but an emanatio, and that the conflicting desires can only coexist in a virtuous union, a remeatio, ordained by "the heavenly Maker [...] who having made man to His own likeness, set him beyond and over all the works of that second nature [...]" (Defence 24). 


\section{Donne's Mediation of Desire and Herbert's Sacramental Eroticism}

John Donne wrote a poem celebrating the Sidneys' Psalms, "Upon the translation of the Psalmes by Sir Philip Sidney, and the Countesse of Pembroke his Sister", which is included in The Divine Poems. In that poem, Donne describes the "Eternall God" as "cornerlesse and infinite", and says that he "would but blesse thy Name, not name thee now" (4-5). Donne's consideration of the manner in which the inexpressible, divine "infinite" beloved ought to be mediated by the physical and finite form echoes the Sidneian Psalmist who physically "taste[s] and see[s]" (29) the grace of God in Psalm 34 (see Chapter Two, p. 68). The influence of the Sidneys' translation of the Psalms on Donne not only demonstrates the continuity of the concept of paradoxical desire that is deeply rooted in the Psalmist as a Neoplatonic lover, but also sets up Donne's exploration of the theological implications of the Neoplatonic assertion that the whole world is a manifestation of the divine.

This exploration interests George Herbert too. In order to express religious desire, both poets, in writing devotional poetry, translate the divine into the physical by perceiving the whole world as a Eucharist, a Sacrament. In Paradoxia Epidemica, Rosalie Colie recognises that Herbert's God is an "immanent God" (210). Robert Whalen extends Colie's insight, commenting that such a God is one "whose involvement in the minutiae of existence is the model for continual poetic recreation" (159). The paradoxical relationship between postlapsarian human nature and the divine nature that Sidney scrutinises was later shared by both Donne and Herbert, and resonated in their respective implementations of sacramental poetics in their articulation of desire. 


\section{1 "contraryes meete in one": Donne's Mediation of Desire}

Helen Wilcox remarks in her chapter "Devotional writing" that at the core of the Christian religion, and of Donne's preoccupation with it, are "impossible possibilities", and that "the centrality of paradoxes" in Donne's religious discourse is a crucial aspect of his devotional writing (151). As a Christian poet-lover composing devotional poetry, Donne's speaker in The Divine Poems experiences "contraryes me[t] in one", as is so clearly expressed in the Holy Sonnet "Oh, to vex me":

$\mathrm{OH}$, to vex me, contraryes meete in one:

Inconstancy unnaturally hath begott

A constant habit; that when I would not

I change in vowes, and in devotione. (1-4)

The paradox in this quatrain operates rhetorically in the poem as a means of argumentation. Yet, more than that, it is used dialectically, as Adlington points out, "in the scholastic sense of the logical pursuit of a priori truth" (349). By evoking a condition of mind where opposing desires wrestle with one another, Donne presents the problem of paradox. The extreme tension between the Christian poet's spiritual desire for fellowship with God and his inherent human reality, which incessantly obstructs him in achieving reconciliation, is demonstrated by the internal conflict between his dual conditions of "devotione" (4), which paradoxically frames the only "constant" (3) in the poet's spiritual life. This religious "Inconstancy" (2), the changeability, seems to be his unchanging nature. The Christian poet-lover is defined by the inseparable disparities between his spiritual love and his bodily desire, which are constituted by such a "devotione", and controlled by a disposition that is "humorous" (5):

As humorous is my contritione

As my prophane love, and as soone forgott:

As ridlingly distemperd, cold and hott,

As praying, as mute; as infinite, as none. (5-8) 
Wilcox describes Donne's language as "the mingling of sacred desire and 'prophane love"" ("Sacred desire, forms of belief" 160). The dual presence of the seemingly contradictory desires within the poet — the fleshly and the spiritual — is the fundamental cause of his devotionally unstable character. This linguistic blurring of differences between bodily and divine love is displayed more explicitly in the earthly imagery of courting. Although anxious and fearful, the Christian poet attentively "court[s]" (10) God, seeing him as his lover, articulating his religious persuasion in an amorous discourse:

In prayers, and flattering speaches I court God:

To morrow'I quake with true feare of his rod.

So my devout fitts come and go away

Like a fantastique Ague: save that here

Those are my best dayes, when I shake with feare. (10-14)

The language Donne uses in this poem reflects his passionate and erotic relationship with God. Paradoxically, "court[ing]" God with "feare" (11) corresponds in some way to the inconstant courtship in the days of his "prophane love". Hence, the paradoxical nature of his desire can be expressed via such a divine courtship, in which spiritual love and amorous language is integrated to "meete in one". Experienced as feeling vexed by "contraryes", for Donne, the ardently spiritual desire for God is nevertheless an amorous and erotic one.

The subject of Donne's Holy Sonnets is not only an exploration of paradoxes in a Christian life as a desiring lover, but also a theological action of searching for resolution of those paradoxes. I have discussed in Chapter One how the paradoxical nature of desire inheres in the poet-lover as a subject. The constant inner conflict of the poet-lover as expressed in conventional Petrarchism, as we have seen developed in Philip Sidney's Astrophil and Stella, can be compared to a new voice in Donne's speaker in his Holy Sonnets after combining with his distinctive understanding of sacramental theology. As I have postulated in Chapter One, some of Donne's poems, such as "The Canonization" and "The Flea", can be interpreted in terms of Christian Platonism, through which lens physical realities including fleshly or bodily 
desire are to be seen as sacramental types pointing to heavenly truths and reflecting divine ideals. "Sacramental" here refers to Christian sacramentology, the theology of Sacraments. In this case, particularly, these poems are related to the Calvinist sacramentology - the officially established position in the Church of England as defined in the Thirty-Nine Articles in Donne's time. In some ways, Calvinist sacramentology is essentially Neoplatonic. Hazlett notes that Reformed sacramental thinking was shaped by "a spiritualising thrust and an aversion to a materialist concept of grace-a sort of [...] inherited Neoplatonism", and that it was a "metaphysical dualism, whereby matter and spirit are antithetical and incompatible" (254). However, there is an inefficacy or inadequacy in the articulation of desire following the performance of Neoplatonism, since transcendental and disembodied love is itself insufficient for a desiring and carnal poet-lover who unavoidably retains that "prophane love". Though occasionally implementing Neoplatonic methods in his amorous poems, Donne might not be a complete Christian Platonist in its true sense. The inadequacy of presupposing Neoplatonism to express Christian desire impels Donne to seek alternative ways.

As the Holy Sonnet "Oh, to vex me" illustrates, the discourse of "prophane love"- the fleshly and bodily desire that contradicts his spiritual love for God-is directed to the articulation of his "contritione" (5), which will finally lead him to salvation. Donne describes this "contritione" as "humorous", which not only means changeable, but also clearly relates to humoral or bodily fluids. He explicitly argues in his Paradoxes and Problems that, "the guifts of the body are better then those of the mind", and that it is the body that "makes the mind" (11). According to Michael Schoenfeldt, Donne claims that virtue is as much a result of bodily fluids (humours) as of divine guidance (Renaissance Transformations 147). In this sense, the desire of the Christian poet is articulated as a paradox effected by the body-mind correlation. The tension between the Christian's spiritual desire for God and his awareness of his carnal and sinful reality is expressed through a poetics in which meta-physical thoughts can be 
pronounced by physical language. Such a paradox of co-present bodily-spiritual desires within the subjectivity of the desiring Christian poet-lover closely parallels the paradox of Christ's dual natures. What Christians yearn to possess and embrace is exactly Christ himself, the Divine incarnated as flesh, or in other words, the divinised humanity. The conflict between spiritual love and physical desire is comprehended as sacramental pairs. The Sacrament is the model according to which the dual presence of the incarnation of Christ is represented. Donne articulates love and desire in The Divine Poems via the system of the Eucharistic poetics by which the paradoxical dyad of body-soul and physical-spiritual love of the Christian lover is conveyed through the elements operating in the Sacrament. ${ }^{58}$

In Donne's Holy Sonnet "I am a little world", the Christian human is presented as "a little world" (1). This is a comparison between the destiny of the poet's own subsistence as the microcosm, and the fate of the macrocosm. Kindred to the universe and just like the rest of God's creation, the poet is made of both "Elements" (the body) and an "Angelike spright" (2); however, because of "black sinne" (3), "both parts" of him "must die" (4):

I AM a little world made cunningly Of Elements, and an Angelike spright; But black sinne hath betraid to endlesse night My worlds both parts, and (oh) both parts must die. (1-4)

Dragged in two different directions, the Christian poet is unable to relinquish the tenacious desires from either his body or his soul. Achsah Guibbory suggests that many of the "tensions and contradictions" in Donne's poems can be perceived as "deriving from wanting to satisfy conflicting human [...] desires" ("John Donne" 143). Moreover, the dualism of body and soul, of flesh and spirit, shows Donne's principle that no aspect of a Christian's theological experience functions exclusively, but, rather, is realised through a paradoxical unity, echoing

\footnotetext{
${ }^{58}$ Cf. Shaun Ross. "Sacramental Signification: Eucharistic Poetics from Chaucer to Milton”. Shaun Ross's thesis inspires my exploration of the intriguing connections between Sacraments and poetics.
} 
his sacramental poetics. For Donne, the proper articulation of desires as a Christian ultimately derives from his accurate comprehension of the relationship between Christ's two natures. To be specific, the sound expression of a poet's spiritual love and his physical desire is necessarily shaped by his true recognition of the basic analogy between Christ's human nature and divine nature, which is displayed and communicated in the sacramental elements' dual identity as religious nourishment.

Reading from the perspective of Donne's sacramental poetics, the crucial phrase "a little world" (1) denotes the place in which both human and the divine, both the microcosm and the macrocosm, are embodied and held. Donne's sermons reveal that he firmly believes in the simultaneous presence of Christ's two natures, which is in conformity with orthodox Anglican doctrines as argued and defended by Thomas Cranmer. ${ }^{59}$ This sacramental theology, which is derived from the Christological doctrine that is orthodox yet undoubtedly paradoxical, evinces one of the most striking "impossible possibilities" of the Christian faith, as Wilcox describes it. Donne insists that the affirmation of this Eucharistic co-presence of the two distinctive yet inseparably associated natures is so important that whoever denies it is tearing apart Christ's entireness, "dissolving" him, and "break[ing] him in peeces" (V 134). In this poem, Donne firstly defines the object of his love, namely God, by paralleling Christ and his hypostatic union with the Christian poet himself, and then explicitly declares his desire to submit his entire being fully to God by invoking the concept of "my world" (8) again:

\section{[...] so I might}

Drowne my world with my weeping earnestly,

Or wash it, if it must be drown'd no more (7-9)

\footnotetext{
59 " $[\mathrm{N}]$ oting St Augustine, that 'as the person of Christ consisteth of two natures, so the sacrament consisteth of two natures, of the elements of bread and wine, and of the body and blood of Christ, and therefore both these natures do remain in the sacrament"'. Cited from Writings and Disputations of Thomas Cranmer Relative to the Sacrament of the Lord's Supper, ed. Rev. John Edmund Cox. Cambridge University Press, 1844. p. 279.
} 
Both parts of him—-his flesh and spirit—are dead in "black sinne" (2-4); therefore, the entire "world" of him desires to be washed clean and purified. However, knowing that God has promised not to destroy the world again with water (9), the Christian poet-lover calls for God's "fiery zeale" (13) in comparison with his sinful "fire" and "flames" (10-12) which is destined to be consumed in the eschatological fire according to 2 Peter 3:10. Yet this fire from God asked for by the poet does not come to consume the "world" (the poet himself being the very "world") in a punitive way, but in a purifying and redemptive way:

But oh it must be burnt; alas the fire Of lust and envie' have burnt it heretofore, And made it fouler: Let their flames retire, And burne me, o Lord, with a fiery zeale Of thee' and thy house, which doth in eating heale. (10-14)

The last three lines of the poem describe the divine fire the poet desires as at the same time eschatological and soteriological. Such a divine fire is concerned closely and simultaneously with both the future reality of the end of the world and the present reality of the poet's personal salvation-his "little world". ${ }^{60}$ More importantly, it relates also to the sacramental. "And burne me, o Lord", the poet desires, by asking and praying for divine "zeale" (13). It is God in Christ that burns the poet; it is Christ's "entireness"—-both his human nature and divine nature - that is inside Donne's microcosm. Anthony Low notes that this "zeale" signals an "active response" to the divine fire (78). The poet-lover's "active response", paradoxically, is his desire to be passively "eaten" by God, for whom such desire is mediated in the poetically Eucharistic feast - the most intimate communion with Christ's dual natures in which he is assured that he will be "healed". ${ }^{61}$ The pronouncement of this kind of paradoxical desire is only possible

\footnotetext{
${ }^{60} \mathrm{P}$. G. Stanwood notes that Donne is "unusually passionate" with the themes of judgement and end times; and that he "seems to speak to us from the depths of private experience, with a considered and uniquely personal voice". See "Sin, Judgement, and Eternity". The Oxford Handbook of Early Modern English Literature and Religion. p. 656.

${ }^{61}$ This is an allusion to Psalm 69:9: "For the zeal of thine house hath eaten me". 1599 Geneva Bible.
} 
through the Eucharistic ritual, in which the word is made flesh, and the physical desire rightfully mirrors that of the spiritual.

The process of this mediation of desire through the working of sacramental poetics is significant. It is during this poetical Eucharist that the physical and spiritual love of the Christian poet lawfully communicate with each other. Just as both human nature and the divine nature of Christ are present during the ceremony of the Holy Sacrament, physical desire and spiritual love are co-present and concurrent as a communion in Donne's poetry. In his Holy Sonnet "Show me deare Christ", Donne portrays the Christian Church as the bride of Christ, a woman who not only consists of a soul and a body, but also a desire that is at once spiritual and bodily. This is something that clearly transcends conventional Petrarchism and its frequent emphasis on the mutually exclusive choice between body and soul. In this poem, Donne characterises the Church, the "spouse" (1) of Christ, as a woman who is sexually open. The poet displays such sexual openness as simultaneously spiritual and bodily. At the beginning of the poem, Donne asks, to which Church do I belong? To the Church of Rome who is the "richly painted" harlot (3) or the Protestant one ("in Germany and here", line 4)? Donne's Holy Sonnets were written during a time of personal religious confusion, as he was experiencing conversion from Roman Catholicism to Anglicanism. ${ }^{62} \mathrm{He}$ contends in a letter: "I never fretted nor imprisoned the word Religion; [...] nor immuring it in a Rome, or a Wittemberg, or a Geneva; they are all virtuall beams of one Sun". ${ }^{63}$ Christ the "Sun" is the one who alone knows the Invisible Church, and who himself instituted the true Church-the "spouse" that Donne searches for in this poem. Is the true Church the Reformed one that "slept" between primitive times and the Reformation for "a thousand [...] yeare[s]", and "then peepes up" (5) with John Calvin? Is she on the "seaven [...] hill[s]" of Rome or in Geneva ("on no hill", line 8)? The

\footnotetext{
${ }^{62}$ See A. J. Smith. John Donne: The Complete English Poems. Penguin Classics, 1977

${ }^{63}$ The letter was possibly written in 1610, the same period of time in which Donne composed his Holy Sonnets. See Letters to Severall Persons of Honour (1651): Scolars' Facsimiles and Reprints. Delmar, 1977. p. 29.
} 
sexual openness of Christ's "spouse" parallels the theological inquiry pronounced by Donne in his yearning to examine the purity of the Church and the identity of the true Church, which is an extended metaphor of the relevant Scriptural sources. The Apostle Paul writes about this in one of the most explicit Eucharistic analogies in Ephesians 5:25-32:

Husbands, love your wives, even as Christ loved the Church, and gave himself for it, that he might sanctify it, and cleanse it [...] make it unto himself a glorious Church, not having spot or wrinkle [...] but that it should be holy and without blame. So ought men to love their wives, as their own bodies [...]. For no man ever yet hated his own flesh, but nourished and cherisheth it, even as the Lord doth the Church. For we are members of his body, of his flesh, and of his bones. For this cause shall a man [...] cleave to his wife, and they twain shall be one flesh. This is a great secret, but I speak concerning Christ, and concerning the Church. (1599 Geneva Bible)

In discussing the relationship between Christian believers and Christ by conjuring up the earthly concept of fleshly love and marriage, Paul constructs a sacramental analogy between human marriage and divine marriage. The nature of matrimonial love as expressed in the husband "nourish[ing] and cherish[ing]" his spouse, and the two experiencing a sexual bond in "one flesh", are all sacramental types reflecting Christ's body and flesh in the Eucharist. This shadows the co-presence of Christ's human nature and divine nature. The Church as a woman has a spiritual love for her husband, Christ, and she has a physical and sexual desire to experience that union of "flesh" with Christ. Moreover, this is sacramentally fulfilled both in marriage and in the language and the poetics itself in which the earthly rightfully corresponds to the heavenly. Once this sacramental poetics is established, Donne can somehow lawfully portray the Church as simultaneously a spiritual object to be adored and a bodily object to be desired in a discourse of sexual courtship. Accordingly, the "spouse" of Christ manifests herself by reaching to such an extension of paradox that she becomes a "holy whore", a whorish 
Bride. ${ }^{64}$ The poet is eager to perceive the true Church in all her unclothed glory (11) so that his "amorous soule" may have communion with her (12). Paradoxically, she is "most trew" (13) to Christ's love and calling when she is sexually "open to" and "embrac'd" by all (14), since "they are all virtuall beams of one Sun":

Betray kind husband thy spouse to our sights, And let myne amorous soule court thy mild Dove, Who is most trew, and pleasing to thee, then When she'is embrac'd and open to most men. (11-14)

Another way in which Donne implements sacramental poetics to mediate the desire of the Christian poet-lover and transmit that desire to the expression of spiritual love is the powerful execution and operation of intimacy as reflected in the significance of the Eucharist. To make it clear, the reason that the "spouse" of Christ in the Holy Sonnet "Show me deare Christ" can be sexually open and even whorishly polygamous in her articulation of desire while conveying spiritual love and devotion, is due to the fact that God became flesh. Donne mediates not only her physical desire, but also her material body itself through a poetics that theologically correlates with her immaterial nature. This seemingly blasphemous action of articulating desire becomes realisable when the fleshly and the sexual rightfully points to that sacred paradox, the Eucharist in which Christ himself — being co-presently human and divineis comprehended.

Guibbory notes that Donne's characterisation of love as both sexual and spiritual is "an erotic reworking of the Catholic understanding that body and soul, material and spiritual are inseparably linked in the world, [...] and in the Sacrament" ("Erotic poetry" 144). The Roman Catholic influence on Donne's sacramentology is indeed evident; however, I argue that in his poetics in the Holy Sonnets, he inclines more to the Lutheran view of consubstantiation, than

\footnotetext{
${ }^{64}$ Robert Whalen uses the word "whorish" to describe the Church in The Poetry of Immanence: Sacrament in Donne and Herbert. p. 29.
} 
to the Roman Catholic view of transubstantiation. This distinction is crucial for understanding his communication of paradoxical desire. Donne says in one of his sermons:

This Sacrament of the Body and Blood of our Saviour, Luther calls safely, Venerabile \& adorabile; for certainly, whatsoever that is which we see, that which we receive, is to be adored; for, we receive Christ. He is Res Sacramenti, The forme, the Essence, the substance, the soule of the Sacrament; [...] To take the body, and not the soule, the bread, and not Christ, is death. (VII 320; italics original)

In Donne's religious poetry, physical love and fleshly desire is the material element, and spiritual love is the divine "substance". The matters of bread and wine do not change or transform into the body and blood of Christ, but they are concurrent with Christ's divine substance, hence, con-substantiation. The love that the poet-lover speaks of in the Holy Sonnets is effectively different from that enjoyed by the lovers in "The Canonization" who have made each other their "hermitage" through the Platonic mechanism. The two experienced that union in one "flesh" through the audacious analogy between Christ's resurrection and sexual orgasm when they "die and rise the same", but their "Myster[y]" is slightly different from the mystery displayed in the Eucharistic rite, which Donne much more explicitly utilises to convey his religious ideas in the Holy Sonnets. Ultimately, the mystery in the Sacrament is that Christians may "receive Christ" (VII 320). As the physical elements in the Eucharist are the means by which the spiritual substance is "receive[d]", so the fleshly desire of the poet-lover is the physical vehicle that intimately figures or represents its spiritual tenor. Consequently, the Christian believers' desire for God's grace in Christ can be safely expressed in such sexual language through the functioning of sacramental poetics.

Donne constitutes the true Church in his Holy Sonnet "Show me deare Christ" as the feminised body of believers by its sexual openness, awaiting ravishment. In "Batter my heart", he demonstrates the desire of the Christian lover in a "feminine persona" who is to be erotically overpowered by the violence of grace of the "masculine God", as Schoenfeldt puts it ("The 
Gender of Religious Devotion" 222). In this gender reversal, the male Christian poet plays the role of a female bride, eagerly desiring the dramatic yet violent intervention of God:

BATTER my heart, three-person'd God; for, you As yet but knocke, breathe, shine, and seek to mend; That I may rise, and stand, o'erthrow mee,' and bend Your force, to breake, blowe, burn, and make me new. (1-4)

The forceful verbs and the alliteration in line 4 display Donne's God in this poem as particularly Calvinistic, as Loewenstein points out, demonstrating the divine power and violence the poet longs for to break his own resistance and to regenerate him. ${ }^{65}$ The intensive execution of intimacy as reflected in the Eucharist - in which Christ's dual natures are simultaneously displayed - provides the poet with a theological justification and a poetical rationalisation to pronounce his demand for an intimate intercourse with God, rendered in the expression of erotic language. In this context, the poet-lover's spiritual love for God is in linguistic and discursive union with his fleshly desire for ravishment. Guibbory observes that metaphor and paradox are viewed "as if they were literally true" when Donne "exploits analogies between sexual and religious love" ("John Donne" 141). The religious love and the sexual desire of the Christian poet are performed in a metaphoric communion in which the two contraries are inseparably united - echoing "contraryes meete in one" in "Oh, to vex me" - and resemble the Holy Communion in which two distinct objects come together in unity. As the word "communion" shows etymologically, the prefix "com" means "together" while "unus" means “one". The co-presence of Christ's human nature and divine nature, according to Donne's sacramentology, accurately resonates in his poetical idea of two seemingly opposites acting as "one". Physical and spiritual desire, sexual and religious love, become paradoxically and sacramentally one desire, and function in "togetherness".

\footnotetext{
${ }^{65}$ Cf. David Loewenstein's chapter "Politics and religion". The Cambridge Companion to English Poetry, Donne to Marvell. p. 11.
} 
Moreover, this metaphoric communion is related to an ancient tradition of using marriage to figure the relationship between the believers and the sacred. The implementing of the erotic symbolism of marriage can be traced back to the tradition of the medieval mystic St. Bernard of Clairvaux who used such imagery to illustrate the union of the soul with God. ${ }^{66}$ Both the Holy Communion and Christian marriage are derived from the Bridegroom-Bride relationship characterising Christ's love for the Church. The idea of mystical marriage provides the poet with a vigorous analogy according to which earthly and sacred lovers share a common desire for union with their beloveds. Hence, sexual "togetherness" and the operation of the Eucharistic elements can be understood as —using Whalen's words - "parallel intimacies" (32). In the poem "Batter my heart", Donne desires God to lust after him just as a man violently desires a woman. However, this relationship is not yet lawful and realisable since he is still "betroth'd" to Satan-God's "enemie" (10), even though he dearly loves God (9). Not able to surrender himself to God, consequently, the Christian poet encourages God's sexual assault and penetration:

Yet dearely'I love you, and would be lov'd faine,

But am betroth'd unto your enemie.

Divorce mee,' untie, or breake that knot againe,

Take mee to you, imprison mee, for I

Except you' enthrall mee, never shall be free,

Nor even chast, except you ravish mee. (9-14)

His marriage to Satan must firstly be broken in order that he can experience the beatific sexual rapture of salvation in another matrimonial union as the "spouse" to God. The verb "breake" in line 11 reiterates the forceful alliteration in line 4 and the verb "batter" in the first line, together with the verbs "enthrall" (13) and "ravish" (14), implying the concept of rape as an action in which one overcomes another person's will. The poet-lover, speaking in a feminine

\footnotetext{
${ }^{66}$ See Itrat Husain. The Dogmatic and Mystical Theology of John Donne. Praeger, 1970.
} 
persona, desires the masculine God to take him/her over completely, conquer his/her will, and "imprison" (12) him/her in Divine love. Such gendering is typical when the trope of Christ as the Bridegroom is evoked. The last two lines contain double paradoxes. First, they tell that only the Christian poet's enthralment to God will enable his/her freedom; and, secondly, paradoxically, they make clear that only through God's ravishment — the act of Divine rapewill he/she be rendered pure and "chast". Especially in these two lines, Donne conflates the holy and the erotic in such a way that "all at once we see the base and the miraculous" (Kerrigan 356). The two seemingly self-contradictory statements in these two lines are perfectly reasonable through the working of sacramental poetics. What is presented here is neither a stress on the dichotomy between the human and the divine, nor a mere juxtaposition of earthly and spiritual desire, but a poetical "Holy Communion" in which the spiritual and the bodily come together as one. The poet-lover's desire for God's love functions as paradoxically as sacramentally.

Similar to the active-passive paradox as discussed in the Holy Sonnet "I am a little world", the poet-lover in "Batter my heart" actively desires to be passively ravished by God. ${ }^{67}$ The word "ravish" (14) — bearing the meaning of "rapture" which has the same Latin root, "raptus", as does the word "rape" - has an instant effect of conveying the idea of brute sexual violence. Theologically, as Elizabeth Clarke and Simon Jackson put it, Donne is possibly underlining "the huge imbalance envisaged by Calvinism in the power relationship between the partners in the marriage" with which the union between the believers and God is portrayed (160-161). Yet, in some sense, such sexual politics as indicated in the poet's fervent desire for a divine rape can also be understood as a religious progression of the seemingly contradictory

\footnotetext{
${ }^{67} \mathrm{Cf}$. Helen Wilcox's discussion of the nature of Donne's representation of spiritual experience in his devotional writing in The Cambridge Companion to John Donne, where she notes that it is "full of anxious energy emotional, linguistic, dramatic, sexual - that nevertheless gives way to passivity as God is asked to [...] 'ravish' the speaker" (165).
} 
sexual fantasies involving alternatively erotic sadism and masochism as incorporated in conventional Petrarchism. Such apparently blasphemous language in Donne's religious poem becomes licit in a Eucharistic poetics in which spiritual eroticism is rightfully established to express the devotional idea that true freedom is dependent on such a desire for spiritual chastity that can only be acquired by means of God's ravishment and articulated in sexual analogy. Kerrigan summarises it well: "It is one thing to run circles of wit about the straight-line orthodoxy of Petrarchan love poets, quite another to bend the cherished corners of dogma" (337). It is noteworthy that the trope of ravishment by God is not unique; nevertheless, Donne achieves this innovatively by performing paradoxical desire through a poetics according to a sacramental theology in which the relationship between the contrasting pairs is equally paradoxical. It is in this poetical Eucharist that the fleshly desire is equated to spiritual passion; and the blasphemy becomes orthodoxy.

Donne's distinctive sacramental view drives his literary attempt to argue for a poetics favourable to him in expressing his paradoxical desire as a Christian. In Donne's religious poems discussed above, spiritual love is mediated through fleshly desire in a sacramental poetics differing from a poetics rooted in the pure Neoplatonic mechanism. Donne says in one of his sermons, "the Holy Ghost is amorous in his Metaphors", and that "everie where his Scriptures abound with the notions of Love [...] and Marriage Supper, and Marriage-Bedde" (VII 87; italics original). In contrast with how Edmund Spenser articulates desire in Amoretti and Epithalamion and the way Sidney characterises his Psalmist David, Donne abandons the Neoplatonic means by which the beloved is always idealised and abstracted as a divine archetype. Instead, he ascribes the fleshly to the poetical Eucharist - the paradox of the mystical marriage where "contraryes meete in one"-and spiritual love is communicated in and through the physical. Theologically, this is in accord with John Calvin's idea that the material nature of the Eucharist is to be perceived as God's graceful "condescension" to 
humanity. ${ }^{68}$ The co-presence of the bodily and the divine in the Sacrament legitimises the endeavoured resolution to release the extreme tension between physical desire and spiritual love in the Christian experience, through paradoxes and the comprehension of sacramental analogy. Thus, as Wilcox indicates, the paradoxical characteristics of Donne's devotional poems are "ultimately, the key to [their ...] implicit hopefulness" ("Devotional writing" 165).

\subsection{Herbert's Sacramental Eroticism: the Paradoxical Formula}

The paradox as expressed in Donne's "contraryes meete in one" in the Holy Sonnet "Oh, to vex me" is in essence an expression of a sacramental tension in the Christian poet's personal experience in which opposite desires are problematically yet realistically co-present. George Herbert articulates such paradoxical desires in many poems in The Temple, with similarities to Donne's Holy Sonnets but also with distinct innovations. Helen Wilcox notes in "Sacred desire, forms of belief' that Herbert's poems differ from Donne's in that his poems are characterised by a "perplexed narrative voice" (161). This perplexity of voice is rooted in the integration of the poet's paradoxical experiences within the self and the significance of the sacramental body of Christ. Take Herbert's poem "Josephs coat" for example, in which the poet's desire to love God is obstructed by sin, hence he has been "Thrown down" (2) by sorrow. Both his "heart" (7) and his "bodie" (9) are owed to "grief" (9); he looks forward to death in which he- -being a corpse - will be carried to the grave by a "biere" (8):

Wounded I sing, tormented I indite,

Thrown down I fall into a bed, and rest:

Sorrow hath chang'd its note $[\ldots]$

Sure it would carrie with it ev'n my heart,

\footnotetext{
${ }^{68}$ Calvin explains, "our merciful Lord, with boundless condescension, [...] declines [...] even in the flesh to exhibit a mirror of spiritual blessings". Cited from The Institutes of the Christian Religion, 4.14.3.
} 
And both would runne untill they found a biere

To fetch the bodie; both being due to grief.

$$
(1-3,7-9)^{69}
$$

The "anguish" (10) depicted above is then put into sharp contrast against "One of Joyes coats" (11), which is the only indirect reference to the title of the poem. As interpreted by Wilcox both in her notes and in "Sacred desire" (162), this "coat" is the typological fulfilment of Joseph's "coat of many colours" in Genesis 37:3. In the Biblical narrative, Jacob gave his son Joseph a coat as a representation of the special love of the father to his special child. According to Christian theological typology, this "coat" foreshadows the flesh—the body and blood—of Christ in the incarnation where he is clothed. It is the "sacramental body" of Christ - as Wilcox phrases it in her note - that promises personal salvation and brings forth "Joyes" and relieves the "anguish" (10) of the Christian poet. The paradoxical experience within the poet's self, namely the concurrence of his "joyes" and "griefs" (line 14; italics original), correlates with the incarnational and sacramental paradox. In other words, because God has taken the garment of human flesh, the Christian can be led to the "joyes" of redemption; though possessing "griefs" (14), he is now delighted to "sing" (14) and praise God's "power" (13) for his "relief" (11):

But he hath spoil'd the race; and giv'n to anguish

One of Joyes coats, ticing it with relief

To linger in me, and together languish.

I live to shew his power, who once did bring

My joyes to weep, and now my griefs to sing. (10-14)

Wilcox further notes that the multi-coloured "coat" has the suggestion of the "contrasting moods and experiences" conveyed from the beginning of the poem, "making up the medley of human life" (162). Particularly in the last line, the poet-speaker tells that his desire experienced an emotional transformation from "griefs" to "joyes" and yet these two

\footnotetext{
${ }^{69}$ All citations from Herbert's The Temple are from The English Poems of George Herbert, ed. Helen Wilcox. Cambridge University Press, 2007.
} 
seemingly contradictory emotions operate at once, causing both "weep [ing]" and "sing[ing]". This poetical and discursive articulation of the paradoxical nature of human inclinations is fundamentally generated from Herbert's perception of Christ's sacramental body as an incarnational paradox. This paradox is constructed on the analogy, according to Whalen, that "a thing can be another thing while not ceasing to be itself, that the Word does not cease being the Word in being united with flesh" (124). The paradoxical desire as expressed in the poet's simultaneously grievous singing and joyful weeping is in parallel with the correlation between his former "anguish" and "Joyes coat" being symbolic of Christ's incarnation. The mixed predisposition of the poet-speaker echoes 2 Corinthians 6:10: "As sorrowful, yet always rejoicing $[\ldots] "{ }^{70}$ This perplexity of voice in devotional expression is the poetical reflection of the inner conflict of the Christian poet's inexplicable desire in which his spiritual yearning for communion with God and his inherently physical vulnerability are co-existent.

The physical clothing of Christ in "Josephs coat", namely his incarnation, is a crucial discursive site where the sacramental typology and the literary embodiment is most clearly conveyed. The Christian poet desires to have an intimate relationship with God, to interact with God in a substantial and tangible sense. This desire is effected through the material and physiological stimulation, which is closely connected to the Eucharistic presence of Christ in the sacramental theory. In "Love-joy", the poet apprehends God through the physical observation ("cast mine eye", line 1) and the subsequent comprehension of double-meaning "letters" (6). An interlocutor ratifies the poet's interpretation of the letters " $J$ and $C$ " (2) as " Joy and Charitie", by adding to it another meaning, "It figures JESUS CHRIST":

$[\ldots]$ It seem'd to me

To be the bodie and the letters both

Of Joy and Charitie. Sir, you have not miss'd,

\footnotetext{
${ }^{70}$ All quotations from the Bible in this section on Herbert are from the King James Version, also known as the Authorised Version, in accordance with Helen Wilcox's edition.
} 
Notable is the word "bodie" (6), which according to Wilcox's note means "embodiment", immediately pointing to the sacrificial body of Christ as represented and communicated in the Eucharist. The word "letters" accentuates the paradoxical association between the meaning (the "bodie") and the "letters" which signify it in abbreviated form. The inexplicable desire for a real and substantial Divine is a paradoxical desire realised in sacramental signs, and therefore is furthermore a sacramental desire. As Whalen phrases it, “[the] need to perceive in creation's signs evidence of divinity is the essence of sacramental desire" (124). The verb "figures" instantly reminds us of Sidney's concept of "figuring forth" as discussed in Chapter One. ${ }^{71}$ The physical letters denote and represent—in the Sidneian sense of "figuring forth" — the person of "JESUS CHRIST" who is behind "Joy and Charitie", the correlation of which not only parallels the paradoxical experience as discussed in "Josephs coat" (co-presently "joyes" and "griefs"), but also suggests the poet's innermost desire for the physical interaction with the divine.

In "Decay", Herbert shows his desire for a physically and substantially interactive God by evoking the Old Testament time when the divinity of God was paradoxically articulated via human and tangible discourse. The poet's articulation of his desire for the physical interaction with the divine can be seen as an externalisation of his inward passion towards God through the operation of visible or sacramental signs (“oak, or bush, or cave, or well”, line 7). As noted by Elizabeth Clarke, Herbert's poems externalise "the inward spiritual holiness which is the essence of Reformed piety" (115-116). In The Temple, the internal and external components of religious desire always reflect the sacramental theories in which the Eucharistic elements are believed to communicate their divine referents. However, since the desire of the postlapsarian human is corrupted and evil, the effective way for the poet to express his desire for God,

\footnotetext{
71 "Figures forth" (A Defence of Poetry 25, 33, 54). See also Donne's amorous poem "The Extasie" (69-72) where "Love" puts forth in the body a "booke" in which his "mysteries" could be read as God's mysteries is to be read in the book of Nature and the book of Scripture.
} 
paradoxically, is to establish a spiritual justification for an affirmative embrace of physicality and sexuality, directing sexual and sensual metaphors, and fleshly desire in serving as a vehicle of Divine grace. ${ }^{72}$ This is made possible by sacramental eroticism in which the body and the soul, the spiritual and the carnal are mysteriously interrelated.

In order to express his religious desire for God, Herbert writes in the tradition of eroslove, engaging with the discourse of Christian eros. For him, this is the immediate way to externalise his inward passion. In some ways, Herbert's characteristically aesthetic eros resembles Spenser's articulation of desire in Amoretti and Epithalamion, as discussed in Chapter Two, in that the divine is portrayed as physically beautiful and attractive to the eye of the soul, which continuously stimulates and progresses the desire of the poet towards spiritual consummation. In "The Starre", the poet presents to us a Neoplatonic utterance of desire when describing God's "face" (2) as surrounded by celestial bodies: "Bright spark, shot from a brighter place, / Where beams surround my Saviours face" (1-2). The poet's veneration of the "Starre" can be categorised as belonging to an aesthetic of eros. However, paradoxically, it is at the same time a chaste eros, a pure one. For Herbert, the sinful desire of the postlapsarian human is not essentially connected with the bodily or sensual nature themselves; hence, the expression of a sanctified desire can be conveyed through erotic metaphors. This is the basic principle of Herbert's sacramental eroticism in which the corporeality of language is poetically associated with the theology of the body as a Sacrament. Echoing the incarnational paradox of Christ's sacramental body as discussed in "Josephs coat", the paradox of the Christian's desire for eros as simultaneously sensual and pure is closely related to the Protestant soteriology in which postlapsarian human body along with the earthly eros is redeemed by Divine grace through the sacrificial body of Christ. Composing within this pattern, Herbert can thus implore

\footnotetext{
${ }^{72}$ On the sacred appropriateness and appropriations of sensuous phenomena in Herbert's language of humandivine communion, see Terry G. Sherwood's chapter "Tasting and Telling Sweetness". Herbert's Prayerful Art. University of Toronto Press, 1989. pp. 57-76.
} 
the "Starre" to "burn" (9) his sinful "lust" (10) while paradoxically pursuing the pure Divine eros:

First with thy fire-work burn to dust

Folly, and worse then folly, lust:

Then with thy light refine,

And make it shine:

So disengag'd from sinne and sicknesse,

Touch it with thy celestiall quicknesse,

That it may hang and move

After thy love. (9-16)

The fires of the chaste eros never burn away the Christian poet's sensual desire. Instead, the poet translates and converts this desire to the "celestiall" site with the "quicknesse" of the Divine, which consequently saves him from "sinne and sicknesse" (13-14). The satisfaction of sensual and erotic desire is concurrently and paradoxically the spiritual desire for God, achieved through sacramental eroticism.

Perhaps a more explicit instance of Herbert's articulation of paradoxical desire as being correlatively sensual and heavenly is in the poem "Love II", in which the imagery of fire appears again as a sacramentally erotic means to construct linguistic parallelism between fleshly art and spiritual truths. The sacramental nature of this parallelism rests in the theological notion that the physically Eucharistic types actually and really participate in conferring Divine grace. Hence, it is made possible that the "lesser [flame]" (2) of human "lusts" (5) stimulates poetic “invention" (6-7):

Immortall Heat, O let thy greater flame

Attract the lesser to it: let those fires

Which shall consume the world, first make it tame;

And kindle in our hearts such true desires,

As may consume our lusts, and make thee way.

Then shall our hearts pant thee; then shall our brain

All her invention on thine Altar lay,

And there in hymnes send back thy fire again. (1-8) 
As the poet-speaker says, the "greater flame" (1) of God's love indeed "Attract[s] the lesser to it" (2). Noteworthy is the adjective "lesser", which indicates primarily the difference in degree rather than distinction in essence. The Divine and human fires (lusts) are substantially the same, and of the same eros, therefore, as desires. As Ryan Netzley notes, the poem sets forth a "contest" between lesser and true desires, contending for "the perpetuation of the latter" (44). Resonating but definitely not identical with the Neoplatonic rejection of earthly love in some of Sidney's sonnets in Astrophil and Stella, Divine love for Herbert does not merely "consume" the poet's "lusts" (5), but principally "kindle[s] in [his] heart [...] true desires" (4).

The consuming vigour of true desire in relation to "lusts" works in a similar way to the "fiery zeale" in Donne's Holy Sonnet "I am a little world" which "doth in eating heale" (13). The desire in Herbert's "Love II" that is "kindle[d]" (4) by "Immortall Heat" (1) correlates exactly with purified "lusts", chaste eros, in the same manner that the sacramental elements communicate the divine truth. While Donne's desire is to be passively "eaten" by God in and through the Eucharistic feast enabled by the double-present natures of Christ, Herbert's heart "pant[s]" (6) for God in a more sensuously experimental way. ${ }^{73}$ For Herbert, true desires are directed back to the Divine "fires" through the poetic "invention" (7) of "hymnes" (8), thus extinguishing his sinful fire, worldly eros. The sacramental nature of this pleasurable experience not only displays itself in the thankful "send[ing] back" (8) of "invention" and the consecration of them "on thine Altar" (7) as Eucharistic gifts, but more instantly, in the parallelism between "sensuous enjoyment" and "spiritual engagement", as Liew indicates (49). Comparatively, Donne's "prophane love" (6) as pronounced in the Holy Sonnet "Oh, to vex me" is more similar to Herbert's Divine "flame" (1) in "Love II" than to his "usurping lust" (12). Yet, the kind of love that is considered "prophane" in Donne's terms is here for

\footnotetext{
${ }^{73}$ The word "pant", meaning desire, echoes Psalm 42:1: "As the hart panteth after the water brooks, so panteth my soul after thee, O God". See also the Geneva Bible and the Sidneys' translation, both of which use the same word.
} 
Herbert the sensual and the sexual eros that is betokened metaphorically and sacramentally in the pure Divine eros. Not surprisingly, as Whalen accurately points out in the chapter "Poetry and Self: The Eucharistic Art of Devotion" in The Poetry of Immanence, this poem suggests "less a strict dualism [...] than a hierarchical contiguity" (164). In other words, the erotic and the spiritual desires of the Christian poet are devised as mutually contiguous rather than being differentiated substantially. Thus, as mentioned earlier, the two "flames" are paradoxically of the same eros, and only differ in degrees of "greater" (1) in contrast to "lesser" (2). Having recognised this "hierarch[y]" of desires, the poet's "eies" (lines 9, 14) are "mend[ed]" and enabled to "see" (9) God:

Our eies shall see thee, which before saw dust;

Dust blown by wit, till that they both were blinde:

Thou shalt recover all thy goods in kinde, Who wert disseized by usurping lust:

All knees shall bow to thee; all wits shall rise,

And praise him who did make and mend our eies. (9-14)

What substantially contradicts God is not "lust" itself - that once positioned rightly, belongs invariably to pure eros-but "usurping lust" (12). This "usurping lust" rejects the crucial recognition that "true desires" (4) belong not to postlapsarian man himself, but should be sacrificed Eucharistically on "thine Altar" (7), otherwise it is no more than-quoting Shakespeare-“"th'expense of spirit in a waste of shame" (Sonnets 129). Interestingly, Malcolmson has argued that the final line of Herbert's "Jordan II", where the poet is advised to "Copie out onely that, and save expense", was possibly an allusion to the above-mentioned Shakespearean verse. ${ }^{74}$ According to Wilcox's note, this line of Herbert's is also a parody of the final line in Sonnet 1 of Sidney's Astrophil and Stella: “[...] looke in thy heart and write". While Sidney's Astrophil attempts to stimulate "Invention" from himself as discussed in

\footnotetext{
${ }^{74}$ See C. Malcolmson. George Herbert: A Literary Life. p. 13.
} 
Chapter One, Herbert is to look into his heart and find God, as can be perceived from the opening lines of the poem "JESU": "JESU is in my heart, his sacred name / Is deeply carved there [...]". Herbert's desire-his "spirit" and "lust"-are not "waste[d]" because he offers them to the pure Divine eros, to his "Starre" and "Immortall Heat", just as The Temple's subtitle "Sacred Poems and Private Ejaculations" suggests. ${ }^{75}$ Such offering up matches the spiritual meaning of "Ejaculation".

Herbert's eroticism is not merely spiritual, but sacramental, significantly relating itself to the power of the Eucharistic elements, the tangible and sensuous physics that communicate the divine and the meta-physics. It is a sacramentally erotic formula that works in paradoxes, powerfully returning the earthly eros to the sacred one. The verse "all wits shall rise" (line 13, "Love II") evokes Sidney's claim that “our erected wit maketh us know what perfection is, and yet our infected will keepeth us from reaching unto it" (Defence 25). Following the liturgical structure of the Sacrament, the poet-speaker, after offering his Eucharistic gifts of "invention" on God's “Altar" (7-8), reflects on his sin of "usurping lust" (12), then surrenders his "infected will" to God's will, and "praise[s] him" (14). Consequently, both his "lesser" (2) desire and his wit shall "rise" through a redeemed eros by a "greater" (1) Love, as the title of the poem indicates.

The "perplexed narrative voice" that Wilcox marks in Herbert's poems functions in a paradoxical application, in which the potentiality of eros, serving as concomitantly contrasting desires, works for an attempted resolution through sacramental performance. The paradoxical experience of the Christian poet, the concurrence of his "joyes" and "griefs" as voiced in "Josephs coat", urges for a sensitivity and sensibility of eros that is sensual and carnal, yet

\footnotetext{
${ }^{75}$ In this sense, for Herbert, the poetic act as a sexual and erotic act may not necessarily be a "site of masturbation" as argued by Jonathan Goldberg and discussed by Elizabeth Clarke and others. Cf. Goldberg, Voice Terminal Echo, pp. 110-111; Clarke, "Herbert's House of Pleasure? Ejaculations Sacred and Profane". George Herbert Journal 19 (1995): pp. 55-71.
} 
"kindl[ing] in our hearts [...] true desires" as pronounced in "Love II" (4). C. A. Patrides claims, "The Eucharist is the marrow of Herbert's sensibility" (17). For Herbert, in "Love II", the effective articulation of such "true desire" of the postlapsarian human is not to be presented by a straightforward denial of eroticism, but by an affirmative embrace of it. By embracing eroticism along with its discourse, the sensual metaphors are directed to serve as a means of delivering God's salvation; and the Eucharist is exactly the poetical and discursive locality where the bodily and the spiritual can be correlated in a mysterious way.

Herbert's poem "The Invitation" illustrates the paradoxes of desire in a more graphic and stimulating manner. The idea of earthly eros redeemed by Divine grace is more vividly portrayed in a corporeal fashion within a literal Eucharistic feast. The poet-speaker proclaims in a preacher's figure, sermonising his congregation as he addresses his poem to the readers. In the poem, the priest of the Eucharist invites sinners to a heavenly feast of Divine love and grace, declaring that only God is able to fulfil the fleshly and sensual desires of postlapsarian humans. Hence, sinners should not seek satisfaction of their desires in the sinful world, but rather, direct those desires to the Divine. In the beginning of the poem, the poet-speaker candidly admonishes those people who approach the Eucharistic altar, telling them that the desires they have now are not "true desires", but the ones that lead to destruction:

Come ye hither all, whose taste

Is your waste;

Save your cost, and mend your fare.

God is here prepar'd and drest, And the feast,

God, in whom all dainties are.

Come ye hither all, whom wine

Doth define,

Naming you not to your good:

Weep what ye have drunk amisse, And drink this, Which before ye drink is bloud. (1-12) 
The Eucharistic meal is compared to the earthly, gluttonous meal that fails to satisfy physical and material desires in that the "taste" (1) of it is simply "waste" (2); and that wine is "drunk amisse" (10) which is considerably unlike that "feast [of] God" (5-6). Thus, gluttons are persuaded that they will feast their desires on "God, in whom all dainties are" (6); drunkards are given "bloud" instead of wine (7-12). Whalen notes in the chapter "Sacramental Puritanism: Herbert's English via media" in The Poetry of Immanence that the structure of the poem "mirrors the paradox of the Word become flesh, made explicit" by the authorial assertion that "the sacramental wine is blood 'before ye drink" (129). The presence and the representation of desire as eros matches not only the incarnational and sacramental significance of Christ in the Eucharist as concurrently divine and human, but also the believers' mystical union with Christ as an experience both spiritual and substantial.

The analogy in stanza 2 concerning wine and blood is at the same instant sacramental and paradoxical. The wine of earthly gratification and the wine of heavenly effects are demonstrably differentiated. However, instead of rebuking the sinners along with their carnal desires, the priest-speaker invites and entices them to turn such desires to the sacramental wine of salvation and says, "drink this" (11), reminding them that this Eucharistic drink is the signified received: "Which before ye drink is bloud" (12). According to Calvin, although "the sign differs essentially from the thing signified", it is not separated "but [...] truly exhibits it" ${ }^{76}$ As the elements of the sacramental wine truly exhibit and mystically convey Christ's "heav'nly bloud" (line 38, "The H. Communion"), the rightful desire for heavenly things does not relinquish its physicality, essentiality, or substantiality. This is where the paradoxical nature of desire is founded. The emphatically corporeal imagination of the sacramentally Real Presence of the Eucharist imposes a disposition of desire as concurrently erotic and pure. The most

\footnotetext{
${ }^{76}$ See The Institutes of the Christian Religion, 4.17.21.
} 
intense of human desires is - as Whalen phrases it-"surpassed only by a joy which nevertheless resembles that which it putatively transcends" (129).

Similarly, in stanza 4 of "The Invitation", the debauched and the worldly are assured a far surpassing "joy" in God:

Come ye hither all, whom joy

Doth destroy,

While ye graze without your bounds:

Here is joy that drowneth quite

Your delight,

As a floud the lower grounds. (19-24)

In a sense, the "joy" offered in the Eucharistic meal is set in direct parallelism with the inferior "joy" of earthly and worldly behaviours, immediately resonating with the "lesser" versus "greater" flames as discussed in the first stanza of "Love II". The "joy" of earthly pleasure that "Doth destroy" in lines 19-20 of "The Invitation" contrasts with the godly "joy" in line 22. The two "joy[s]" are of the same kind of desire just as the two "flame[s]" in "Love II" are of the same eros. While the two "flame[s]" differ in degree, the desires that generate different "joy[s]" vary simply in directions. As noted by Richard Strier, in this poem, Herbert depicts sinners, particularly those indulging in sensual and physical excess, as "people with all the right instincts" who are merely seeking satisfaction in the wrong places. The Eucharist is portrayed as "the ideal fulfilment" of the desires involved in sinning (28). The objects, not the desires themselves, need to be changed. Sherwood provides a related but not necessarily identical perspective by emphasising the conformity of earthly tastes and heavenly truths in the "sweetness" at the centre of the poem. ${ }^{77}$ This can be contrasted with Sidney's Psalm 34 as discussed in Chapter Two concerning the Neoplatonic comprehension of "taste and see". The purposive addition of the adjective "sweet" reflects the Sidneian Neoplatonic discourse of

\footnotetext{
${ }^{77}$ See Terry G. Sherwood. Herbert's Prayerful Art. pp. 70-71.
} 
reaching to the meta-physical God through experiencing the physical medium: "[...] taste and see, / How sweet, how gracious is His grace" (29-30). However, this is not accurately the same experience or "taste" of God that Herbert demands in "The Invitation". For Herbert, God is not a being meta-physically and distantly out there in heaven; rather, "God is here prepar'd and drest" (4; italics mine); "Taste and fear not: God is here / In this cheer" (16; italics mine). God is sensually present to the eros of the Communion receivers; and paradoxically, he is as physically real to the desires of the faithful as their sinful desires are carnally real for the food and drink in their debauchery.

In stanza 5 of the poem, the paradoxical formula and the sacramental eroticism move to the next stage where the Divine love incorporated in the Eucharist is marked by the word “death" (lines 29,30). This implicitly links to sexual fulfilment, a conceit typical of Donne yet uncharacteristic for Herbert:

Here is love, which having breath Ev' $n$ in death, After death can never die. (28-30)

The eroticism audaciously suggests the Eucharistic sacrifice, alluding to Christ's crucifixion and resurrection, which is the very origin of the redemption that is celebrated in the Eucharistic feast. Whalen confirms, “[T]he paradox that lovers' orgasm signals the obsolescence of their efforts is analogous" to the theological significance of Christ's crucifixion and resurrection (129). As sacred love is articulated in erotic terms through a linguistic incarnation, pure Divine eros is discursively incarnated into the sensual and fleshly desire. Herbert's sacramental eroticism, based on incarnational theology, is ultimately consummated in his poem "Love (III)". Wilcox notes that Sidney's translation of Psalm 23 "closely anticipates" the tone of Herbert's "Love (III)". Indeed, the poetic languages of sensuality in these two poems resemble each other. However, compared with lines 16-21 of Sidney's Psalm 23 concerning the Lord's "table", Herbert's feast is much more explicitly sensual and relates meaningfully to the eros. 
Sidney's Neoplatonic Psalmist desires the "unspeakable and everlasting beauty", though expressing it in sensual terms via aesthetic eros, yet seeing it only "by the eyes of the mind" (Defence 22). Herbert articulates religious desire as concurrently sexual and divine in a peculiar way by which the paradox of desire is subsumed into the sacramentally erotic discourse, reflecting the Eucharistic doctrine of Real Presence in which the gustatory sense and the erotic sense are in (con)fusion. The perplexity and complexity of such a (con)fusion is the logical consequence of the problematically operational dis-concordance between the sensual and spiritual desires of the postlapsarian human. The Christian poet desires to serve God but he is obstructed by "shame" (13). Thus, it is left for God to invite the poet to the heavenly banquet in which the person of God-incarnate is the food of the Eucharistic elements:

Truth, Lord, but I have marr'd them: let my shame

Go where it doth deserve.

And know you not, sayes Love, who bore the blame?

My deare, then I will serve.

You must sit down, sayes Love, and taste my meat:

So I did sit and eat. (13-18)

The sense of "taste" (17), as the ultimate potentiality of inviting the Christian poet to access and receive God as truly present and physically intimate, is gustatory, yet fuses with the erotic. The etymological relation of the word "meat" (17) in its Latin, carne, has the connotation of Christ's incarnation. Christ who, in Calvin's words, "exhibits and offers" himself is both the courteous host of the Eucharistic meal and the sacramental "host" that is the meal. ${ }^{78}$ Worth noticing is the capitalised "Love" (17) which is at the same time the objectified Christ himself and the Divine Eros personified. The phrase "taste my meat" mirrors closely Mark 14:22 where Christ says "Take, eat: this is my body". The desire of the poet is to be satisfied-both physically and spiritually_ through union and communion with the Divine eros exhibited in

\footnotetext{
${ }^{78}$ See The Institutes of the Christian Religion, 4.17.10.
} 
Christ's sacramental body-his "meat" (carne); hence, it is an erotic desire with all the substantial elements of sensuality and physiology.

\subsection{Conclusion}

The paradoxical desire effected by the incarnational paradox of Christ in the sacramental performance is certainly found in Donne's Holy Sonnets but is even more explicitly presented in Herbert's The Temple. The highly esteemed Bishop Lancelot Andrewes, a friend of Herbert and an influence on him, says of the Eucharist:

As to the Real Presence we are agreed; [...] As to the mode we define nothing rashly, nor anxiously investigate, any more than in the Incarnation of Christ we ask how the human is united to the divine nature in One Person. (Responsio 263)

Christ is "a sacrifice—so, to be slain; a propitiatory sacrifice—so, to be eaten." (Sermons, vol. ii. 296) $)^{79}$

The perplexity of poetic voice as reflected throughout The Temple in Herbert's spiritual struggles can be understood as an expression of his paradoxical desire for union with God by physically and erotically engaging with him. Moreover, this physical engagement and active partaking of God is set out by the consuming — or more specifically_eating of Christ in the Eucharist. The incarnational paradox of Christ's sacramental body provides poetic desire with a theological basis, and renders a linguistic justification for religious eroticism. Michael Schoenfeldt suggests that for Herbert, sexual analogies portraying human-divine love persist as lawful and illicit concurrently (Prayer and Power 231). This is true for Donne too. However, another problem remains. While the earthly eros of the postlapsarian human body is redeemed by God through the sacramental and sacrificial body of Christ, is the language of desire

\footnotetext{
${ }^{79}$ David Scott mentions in "Pastoral Tradition in Religious Poetry" that Bishop Lancelot Andrewes was one of Herbert's “increasing influence of friends". See The Oxford Handbook of English Literature and Theology, ed. Andrew Hass, David Jasper, and Elisabeth Jay. Oxford University Press, 2018. p. 730.
} 
redeemed too? The Christian's desire for eros is in itself not only paradoxical but also insolubly problematic. Perhaps, the paradox of the Christian's desire in Donne and Herbert's poems ultimately comes from the inevitability of evincing prelapsarian reality via postlapsarian discourse. Within such discourse, endeavouring to convey his inward spiritual experience authentically, the devotional poet can only foreshadow an uncontaminated desire of a prelapsarian past, instead of embodying it in a complete sense. As Herbert confesses in his "Miserie":

[...] when we speak of thee:

How shall infection

Presume on thy perfection? (34-36) 


\section{Conclusion}

In A Defence of Poetry, Sidney celebrates rhetorical paradoxes by noting that in them "good lie[s] hid in nearness of the evil" (49). He then refers to the giant of Renaissance paradoxy, Erasmus and his “commending of folly". In response to "poet-haters", Sidney defends paradox as he defends poetry itself. In the same way, I argue in this thesis that as paradoxes involve in the poetry of desire, they also inevitably engage in desire itself. Writing partly in the convention of the Petrarchan love-lyric, Sidney presents the poet-lover Astrophil who experiences the tension between the pursuit of Platonic "Beautie" and the fancy for the physical satisfaction with the beloved. While this paradox of simultaneously attempting to maintain contradictory inclinations appears experimental in its immediate poetical expressions, it is also a linguistic paradox.

We have to take into consideration that Astrophil is not only a lover, but also a poet; hence, a poet-lover. His task is not only to desire Stella, but also to articulate that desire, even if that is not entirely possibly. The extremes discussed in Chapter One-the gap between which needed to be filled - are essentially linguistic ones. As Astrophil desires Stella, he also engages in writing poetry, applying earthly words and languages to compose what he sees in Stella as the heavenly "Vertue". In addition, writing as the fictional Astrophil, the real poet Sidney is demanding that the reader employ a rightful reading of such desire for Stella's "beautie" in order to learn the "Vertue" that is "best lodg'd in" it:

WHO will in fairest booke of Nature know, How Vertue may best lodg'd in beautie be, Let him but learne of Love to reade in thee, Stella, those faire lines, which true goodnesse show.

(lines 1-4, Sonnet 71) 
The paradox of such antithesis as desired by Astrophil needs to be understood by the reader within an "antithetical action" of reading (Malloch 192). Such a reading action is in itself paradoxical, since it relies on the equivocation of the authorial balancing of the contradictions "in the equivocal balance in which paradoxy excels" (Paradoxia Epidemica 38). The failure to achieve that balance in the poet-lover's terms analogises the frustration of reconciling the logically contradictory and antithetical inclinations of the desiring subject. The paradoxical nature of Astrophil's desire is displayed as the poet-lover aiming for that ideal love and concurrently directing that aspiration in correlation with the earthly and fleshly love. Inevitably, the writing of that desire for the heavenly constantly drags the poet back down to the earthly discourse, resulting in the paradoxical poet-lover Astrophil's failure both as a lover and as a poet who does not "learn aright why and how that maker made him" (Defence 24). Each one of the poets this thesis explores tries to address this problem.

On this point, a poet-lover should recognise that to desire is to write about desire. Moreover, to write about desire is to imitate the creative act of "that maker" and to write about God. This creative act unavoidably leads the poet-lover to paradoxes. Indeed, God has made the "fairest booke of Nature" (Sonnet 71), and the rightful poet should make, in poetry, the "second nature" (Defence 24) of the desired object. Donne presents the "patterne of our love" (line 45, "The Canonization") as consequential of the paradoxical desiring relationship. Yet even such a "patterne" is inevitably overly abstract and metaphysical, and the representation of it is linked with desire as merely a Neoplatonic copy that needed to be extracted, since human desire is never "so pure, and abstract" (line 11, "Loves growth"). In order to efficiently write about paradoxical desire, the poet needs either to find or to establish a discursive realm where the antithesis of the physical and the spiritual is harmonised and balanced, and where the two qualities "lie hid in nearness" to one another. Spenser's response to the problem is to celebrate such a desire within "the sacred world" (Dasenbrock 46) of Christian marriage where fleshly 
desire for his beloved is both theologically and linguistically justified, as he does in Amoretti and Epithalamion. So does the Sidneian Psalmist, who recognises that the earthly world including himself as a Neoplatonic lover is but an emanatio, and that contradictory desires can only coexist in an immaculate union consecrated by "the heavenly Maker [...] who having made man to His own likeness, set him beyond and over all the works of that second nature [...]" (Defence 24).

However, Neoplatonism is never the final solution to the problem of the articulation of paradoxical desire, since the earthly lover would never utterly relinquish physical realities, and carnal impulses constantly draw the desiring subject to the tangible and the sensuous. The desire to have an expressively passionate relationship with the divinely epitomised object is representational, epistemological, and semiotic. Such a relationship between God and the "second nature" of the poet is also genuinely a relationship between the desiring speaker and his words by which God is represented. Paradox, as Rosalie Colie finds, can never "be suppressed by homo loquens, given the peculiarities inherent in matching words to things. [...] language always limits [...] it is never fully adequate to its referent" (516). Sidney's remark that in rhetorical paradoxes "good lie[s] hid in nearness of the evil" is therefore a comment "on the contradictory merits of the disability under which all language, and all figures, must work" (Colie 516). The linguistic obstacle to the representational desire of paradox is related to paradoxes in divine ontology, the inescapable paradoxes of the infinite. Put differently, to resolve the paradox of desire is to resort to the limited language of the postlapsarian lover to express proximity to an unlimited God. How could finite discourse enter an infinite space? This thesis has tried to argue that Spenser gives an answer by making desire "chast" as he does in Amoretti, while Donne and Herbert attempt to answer it by engaging in a sacramental poetics.

Herbert's poetical suggestion of the "instrumental and not merely representational" (Whalen 118) power of the paradoxy in the Eucharistic performance is indeed an efficacious 
means of articulating paradoxical desire. For Donne, the mutually exclusive aspiration for the bodily and for the spiritual is an intrinsic delusion of both Petrarchan and Neoplatonic principles. The "strict dichotomy" (Raiger 32) between contrary objects on which Protestant poetics is established is dissolved as the poetical Eucharist obtrudes into the presupposition of the epistemological gap between the poet and God. If the endeavour to express paradoxical desire parallels the ultimate task to correlate the sign with the things signified, the devotional poets must answer the question: is it possible for love poetry or language to achieve that? In addition, to what extent could that be achieved? This again refers to Colie's discussion concerning "matching words to things" (516). Another early modern religious writer, Thomas Browne, declares, "There are wonders in true affection: it is a body of Enigma's, mysteries, and riddles; wherein two so become one, as they both become two" (The Second Part VI). This notion precisely elucidates Donne's and Herbert's latent answer to the above-mentioned semiotic question by their application of Eucharistic poetics, in which the paradoxical dyad of physical-spiritual desire of the Christian poet-lover is conveyed through the elements operated in the Sacrament. Donne's Holy Sonnets, such as "Batter my Heart", do not present a linguistic insistence on the dichotomy between human and God, but a poetical Eucharist in which the spiritual and the bodily "so become one, as they both become two". Following Donne, Herbert's sacramental eroticism as discussed in Chapter Three asserts as well that to reject the language of the bodily is to deny utterly the truthfulness of physicality according to which, paradoxically, the meta-physical truths of the incarnation and the resurrection are constructed.

This has been the central argument of this thesis. Once the ideal is established in the real, language itself possesses correlations and analogies working within paradoxes that potentially enable the poet-lovers to speak the unspeakable, and to desire the unobtainable. However, some further questions have been raised during this metaphysical exploration. If sacramental signs are "mediatory, representational [and] with transcendent value" (Whalen 
161), and the writing of love poetry is an everlasting aspiration of fleshly manifestation of the essence, to what extent are poets able to fulfil that? Though it may not be the only approach to answering this question, this thesis has attempted to provide a response by offering comparative analyses of the poetry of Sidney, Spenser, Donne, and Herbert, putting them in the relevant philosophical and theological contexts, and presenting as contiguous their intensive engagement with paradoxical desires. 


\section{Works Cited}

1) Primary texts

Donne, John. The Divine Poems, ed. Helen Gardner. Oxford University Press, 1952.

John Donne: The Complete English Poems, ed. C. A. Patrides. Everyman's

Library, 1985.

John Donne's Poetry (Norton Critical Editions). W. W. Norton \& Company, 2007.

The Sermons of John Donne, ed. George R. Potter and Evelyn M. Simpson.

University of California Press, 1953-1962.

John Donne: Paradoxes and Problems, ed. Helen Peters. Oxford University

Press, 1980.

Devotions Upon Emergent Occasions, ed. Anthony Raspa. McGill-Queen's

University Press, 1975.

Herbert, George. The English Poems of George Herbert, ed. Helen Wilcox. Cambridge University Press, 2007.

Sidney, Philip. The Poems of Sir Philip Sidney, ed. William A. Ringler, Jr. Oxford University Press, 1962.

A Defence of Poetry, ed. J.A. Van Dorsten. Oxford University Press, 1966.

----------. The Sidney Psalter: The Psalms of Sir Philip and Mary Sidney, ed. Hannibal Hamlin et al. Oxford University Press, 2009.

Spenser, Edmund. The Yale Edition of the Shorter Poems of Edmund Spenser, ed. William A. Oram et al. Yale University Press, 1989. 


\section{2) Criticism}

Abrams, M. H. A Glossary of Literary Terms. Earl McPeek, 1999.

Adlington, Hugh. "John Donne". The Oxford Handbook of Early Modern English Literature and Religion, ed. Andrew Hiscock and Helen Wilcox. Oxford University Press, 2018.

Alexander, Gavin. "Loving and Reading in Sidney". Studies in Philology, vol. 114, no. 1, Winter 2017, pp. 39-66. University of North Carolina Press, 2017.

Bates, Catherine. "Desire, discontent, parody: the love sonnet in early modern England". The Cambridge Companion to the Sonnet, ed. A.D. Cousins and Peter Howarth. Cambridge University Press, 2011.

Biester, James. Lyric Wonder: Rhetoric and Wit in Renaissance English Poetry. Cornell University Press, 1997.

Browne, Thomas, Sir. Religio Medici. Vol. 3, Part 5. The Harvard Classics, ed. Charles W. Eliot. P. F. Collier \& Son, 1909-14.

Calvin, John. The Institutes of the Christian Religion, trans. Henry Beveridge. Christian Classics Ethereal Library, 2002.

Childs, Peter et al. The Routledge Dictionary of Literature Terms. Routledge, 2006.

Cirillo, A. R. "Spenser's Epithalamion: The Harmonious Universe of Love". Studies in English Literature, 1500-1900, vol. 8, no. 1, The English Renaissance, Winter, 1968, pp. 19-34. Rice University.

Clarke, Elizabeth. Theory and Theology in George Herbert's Poetry. Clarendon, 1997.

Clarke, Elizabeth and Simon Jackson. "Lyric Poetry". The Oxford Handbook of Early Modern English Literature and Religion, ed. Andrew Hiscock and Helen Wilcox. Oxford University Press, 2018.

Colie, Rosalie. Paradoxia Epidemica: The Renaissance Tradition of Paradox. Princeton University Press, 1966. 
Dasenbrock, Reed Way. "The Petrarchan Context of Spenser's Amoretti”. PMLA, vol. 100, no.1, Jan. 1985, pp. 38-50.

DiPasquale, Theresa M. Literature and Sacrament: the Sacred and the Secular in John Donne. Duquesne University Press, 1999.

Dubrow, Heather. Echoes of Desire: English Petrarchism and its Counterdiscourses. Cornell University Press, 1995.

Duncan-Jones, Katherine and Jan Van Dorsten, eds. "Commentary". Miscellaneous Prose of Sir Philip Sidney. Clarendon Press, 1973.

Greene, Roland et al. ed. The Princeton Encyclopedia of Poetry and Poetics, Fourth Edition. Princeton University Press, 2012.

Guibbory, Achsah. "Donne, Milton and Holy Sex". Milton Studies, vol. 32, 1995, pp. 3-21. In Achsah Guibbory. Returning to John Donne. Ashgate Publishing Company, 2015. pp. 107-125.

"Erotic poetry". The Cambridge Companion to John Donne, ed. Achsah Guibbory. Cambridge University Press, 2006.

. "Fear of 'loving more': Death and the Loss of Sacramental Love". John

Donne's “desire of more:" The Subject of Anne More Donne in His Poetry, ed. M.

Thomas Hester, ed. Associated University Presses, 1996. pp. 204-227. “John Donne”. The Cambridge Companion to English Poetry, Donne to Marvell, ed. Thomas N. Corns. Cambridge University Press, 1997.

Hazlett, Ian. "Church and Church/State Relations in the Post-Reformation Reformed Tradition”. The Oxford Handbook of Early Modern Theology, 1600-1800, ed. Ulrich L. Lehner, Richard A. Muller, and A. G. Roeber. Oxford University Press, 2018.

Kalstone, David. Sidney's Poetry: Contexts and Interpretations. Harvard University Press, 1965. 
Kerrigan, William. "The Fearful Accommodation of John Donne". English Literary Renaissance, vol. 4, no. 3, Autumn 1974, pp. 337-363.

Lambert, James S. "Spenser's Epithalamion and the Protestant Expression of Joy". Studies in English Literature 1500-1900, vol. 54, 2014, pp. 81-103.

Larsen, Kenneth J. Edmund Spenser's Amoretti and Epithalamion: A Critical Edition. Medieval \& Renaissance Texts \& Studies, 1997.

Lear, Anne. "Renaissance Poetry and the Psalms: Influences and Problems". Religion, Literature and the Arts Project. Conference Proceedings of the Australian International Conference, 1994.

Lewalski, Barbara K. Protestant Poetics and the Seventeenth-Century Religious Lyric. Princeton University Press, 1979.

Liew, Warren M. "Reading the Erotic in George Herbert's Sacramental Poetics". George Herbert Journal, vol. 31, Nos 1 and 2, Fall 2007/Spring 2008, pp. 33-62.

Low, Anthony. The Reinvention of Love: Poetry, politics and culture from Sidney to Milton. Cambridge University Press, 1993.

Malloch, A. E. "The Techniques and Function of the Renaissance Paradox". Studies in Philology, vol. 53, no. 2, Apr. 1956, pp. 191-203. University of North Carolina Press.

Marquis, Paul A. "Rereading Sidney’s 'Certain Sonnets””. Renaissance Studies, vol. 8, no. 1, March 1994, pp. 65-75. Wiley.

Mazzeo, Joseph Anthony. "A Critique of Some Modern Theories of Metaphysical Poetry". Modern Philology, vol. 50, 1952, pp. 88-96. Rpt. Seventeenth Century English Poetry. Revised ed. William R. Keast. Oxford University Press, 1971.

Netzley, Ryan. "Take and Taste, Take and Read: Desiring, Reading, and Taking Presence in George Herbert's The Temple". Reading, Desire, and the Eucharist in Early Modern Religious Poetry. University of Toronto Press, 2011. 
Patrides, C. A. The English Poems of George Herbert. Rowman Littlefield, 1975.

Perry, Nandra and Robert E. Stillman. "Philip Sidney and Mary Sidney Herbert: Piety and Poetry". The Oxford Handbook of Early Modern English Literature and Religion, ed. Andrew Hiscock and Helen Wilcox. Oxford University Press, 2017.

Plato. Apology, trans. Benjamin Jowett. CreateSpace Independent Publishing Platform, 2016. Prescott, Anne Lake. "King David as a 'Right Poet': Sidney and the Psalmist”. English Literary Renaissance, vol. 19, no. 2, Spring 1989, pp. 131-151. The University of Chicago Press. Price, Michael W. “The paradox”. The Oxford Handbook of John Donne, ed. Dennis Flynn, M. Thomas Hester, and Jeanne Shami. Oxford University Press, 2018.

Raiger, Michael. "Sidney’s Defense of Plato". Religion \& Literature, vol. 30, no. 2, Summer 1998, pp. 21-57. The University of Notre Dame.

Ricks, Don M. "Persona and Process in Spenser's 'Amoretti'”. ARIEL, vol. 3, no. 4, Oct. 1972, pp. 5-15.

Robinson, Forrest G. The Shape of Things Known: Sidney's 'Apology' in its Philosophical Tradition. Harvard University Press, 1972.

Sanders, Andrew. The Short Oxford History of English Literature. Clarendon Press, 1996.

Saunders, Ben. Desiring Donne, Poetry, Sexuality, Interpretation. Harvard University Press, 2006.

Schoenfeldt, Michael. “The Gender of Religious Devotion: Amelia Lanyer and John Donne”. Religion and Culture in Renaissance England, ed. Claire McEachern and Debora Shuger. Cambridge University Press, 1997.

Prayer and Power: George Herbert and Renaissance Courtship.

University of Chicago Press, 1991.

Renaissance Transformations, The Making of English Writing (1500-

1650). Edinburgh University Press, 2009. 
Sheavyn, Phoebe. The Literary Profession in the Elizabethan Age. Haskell House Publishers, 1964.

Siegel, Paul N. "The Petrarchan Sonneteers and Neo-Platonic Love”. Studies in Philology, vol. 42, no. 2, Apr. 1945, pp. 164-182. University of North Carolina Press.

Stachniewski, John. "John Donne: The Despair of the 'Holy Sonnets"”. ELH, vol. 48, no. 4, Winter 1981, pp. 677-705. The Johns Hopkins University Press.

Strier, Richard. "Changing the Object: Herbert and Excess". George Herbert Journal, vol. 2, no. 1,1978 , pp. 24-37.

Targoff, Ramie. John Donne, Body and Soul. University of Chicago Press, 2008.

Waller, G. F. “"This matching of contraries': Calvinism and courtly philosophy in the Sidney Psalms”. English Studies, vol. 55, no. 1, 1974, pp. 22-31.

Ward, Thomas. "Sounding Devotion in George Herbert's Temple". English Literary Renaissance, vol. 47, no. 1, 2017. English Literary Renaissance, Inc.

Whalen, Robert. The Poetry of Immanence: Sacrament in Donne and Herbert. University of Toronto Press, 2002.

Wilcox, Helen. "Devotional writing", The Cambridge Companion to John Donne, ed. Achsah Guibbory. Cambridge University Press, 2006.

" "Sacred desire, forms of belief: the religious sonnet in early modern Britain".

The Cambridge Companion to the Sonnet, ed. A. D. Cousins and Peter Howarth. Cambridge University Press, 2011.

Zickler, Elaine Perez. “"nor in nothing, nor in things': the Case of Love and Desire in Donne's Songs and Sonets”. John Donne Journal, vol. 12, nos 1-2, 1993, pp. 17-39. 